\title{
Classification and Mapping of Agricultural Land for National Water-Quality Assessment
}

By Robert J. Gilliom and Gail P. Thelin

National Water-Quality Assessment Program

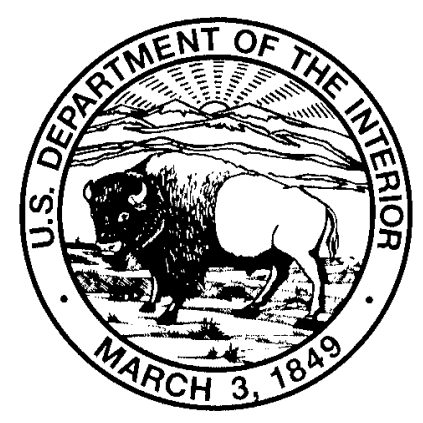





\section{Classification and Mapping of Agricultural Land for National Water-Quality Assessment}

By Robert J. Gilliom and Gail P. Thelin

National Water-Quality Assessment Program

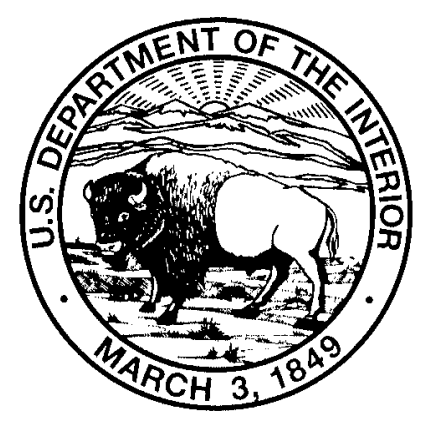




\title{
U.S. DEPARTMENT OF THE INTERIOR BRUCE BABBITT, Secretary
}

\author{
U.S. GEOLOGICAL SURVEY \\ Gordon P. Eaton, Director
}

\begin{abstract}
The use of firm, trade, and brand names in this report is for identification purposes only and does not constitute endorsement by the U.S. Government
\end{abstract}

\section{U.S. GOVERNMENT PRINTING OFFICE : 1997}

Free on application to the:

U.S. Geological Survey

Information Services

Box 25286, Federal Center

Denver, Colorado 80225
For additional information write to:

Chief, Pesticides National Synthesis Project, NAWQA

U.S. Geological Survey

Placer Hall, Suite 2012

6000 J Street

Sacramento, California 95819-6129

\section{Library of Congress Cataloging in Publications Data}

Gilliom, Robert J.

Classification and mapping of agricultural land for national water quality assessment / by Robert J. Gilliom, and Gail P. Thelin.

p. c.m. - (U.S. Geological Survey circular ; 1131)

Includes bibliographical references.

1. Agricultural mapping—United States. 2. Land use, Rural—United States. 3. Water Quality-United States. I. Thelin, Gail P. II. Title. III. Series.

S494.5.C3G54 1997

333.76'0973-dc20 


\section{FOREWORD}

The mission of the U.S. Geological Survey (USGS) is to assess the quantity and quality of the earth resources of the Nation and to provide information that will assist resource managers and policymakers at Federal, State, and local levels in making sound decisions. Assessment of water-quality conditions and trends is an important part of this overall mission.

One of the greatest challenges faced by waterresources scientists is acquiring reliable information that will guide the use and protection of the Nation's water resources. That challenge is being addressed by Federal, State, interstate, and local water-resource agencies and by many academic institutions. These organizations are collecting water-quality data for a host of purposes that include: compliance with permits and water-supply standards; development of remediation plans for specific contamination problems; operational decisions on industrial, wastewater, or watersupply facilities; and research on factors that affect water quality. An additional need for water-quality information is to provide a basis on which regionaland national-level policy decisions can be based. Wise decisions must be based on sound information. As a society we need to know whether certain types of water-quality problems are isolated or ubiquitous, whether there are significant differences in conditions among regions, whether the conditions are changing over time, and why these conditions change from place to place and over time. The information can be used to help determine the efficacy of existing waterquality policies and to help analysts determine the need for and likely consequences of new policies.

To address these needs, the U.S. Congress appropriated funds in 1986 for the USGS to begin a pilot program in seven project areas to develop and refine the National Water-Quality Assessment (NAWQA) Program. In 1991, the USGS began full implementation of the program. The NAWQA Program builds upon an existing base of water-quality studies of the USGS, as well as those of other Federal, State, and local agencies. The objectives of the NAWQA Program are to:

- Describe current water-quality conditions for a large part of the Nation's freshwater streams, rivers, and aquifers.

- Describe how water quality is changing over time.
- Improve understanding of the primary natural and human factors that affect water-quality conditions.

This information will help support the development and evaluation of management, regulatory, and monitoring decisions by other Federal, State, and local agencies to protect, use, and enhance water resources.

The goals of the NAWQA Program are being achieved through ongoing and proposed investigations of 59 of the Nation's most important river basins and aquifer systems, which are referred to as study units. These study units are distributed throughout the Nation and cover a diversity of hydrogeologic settings. More than two-thirds of the Nation's freshwater use occurs within the 59 study units and more than twothirds of the people served by public water-supply systems live within their boundaries.

National synthesis of data analysis, based on aggregation of comparable information obtained from the study units, is a major component of the program. This effort focuses on selected water-quality topics using nationally consistent information. Comparative studies will explain differences and similarities in observed water-quality conditions among study areas and will identify changes and trends and their causes. The first topics addressed by the national synthesis are pesticides, nutrients, volatile organic compounds, and aquatic biology. Discussions on these and other waterquality topics will be published in periodic summaries of the quality of the Nation's ground and surface water as the information becomes available.

This report is an element of the comprehensive body of information developed as part of the NAWQA Program. The program depends heavily on the advice, cooperation, and information from many Federal, State, interstate, Tribal, and local agencies and the public. The assistance and suggestions of all are greatly appreciated.

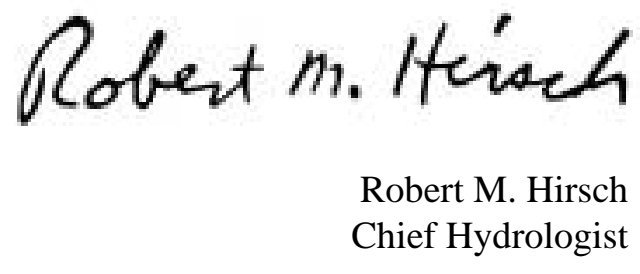


BLANK PAGE 


\section{CONTENTS}

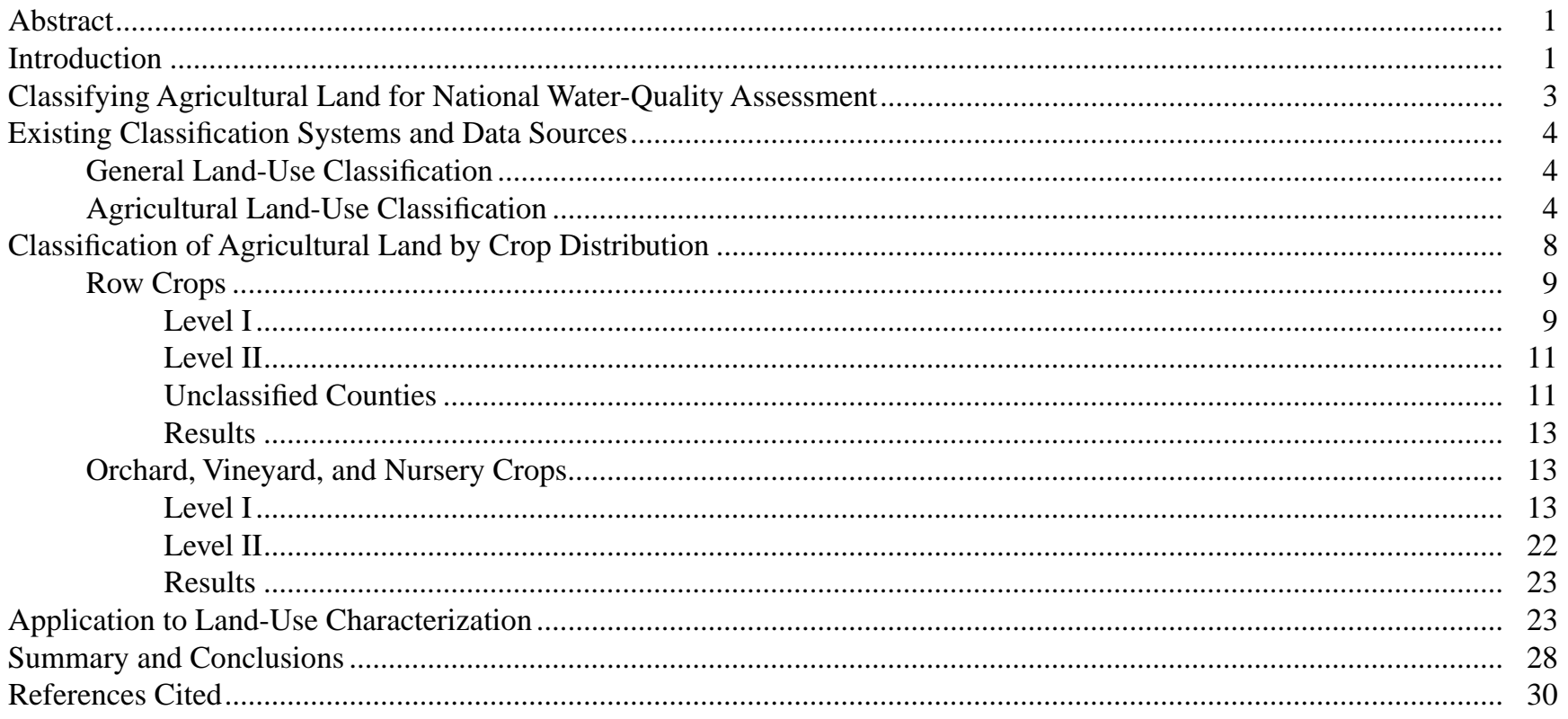

\section{FIGURES}

1.-3. Maps showing:

1. Study Units of the National Water-Quality Assessment.

2. General land use in the Lower Susquehanna River Basin NAWQA Study Unit based on U.S. Geological Survey National Land Use and Land Cover (LULC) data

3. Twelve multicounty clusters showing patterns of agricultural diversity in the United States

4. Summary of decision process for creating categories for row-crop classification

5.-13. Maps showing:

5. Distribution of row crops in the United States

6. Distribution and classification of counties not initially classified by numerical criteria for row crops

7. Distribution of row crops in the "corn, soybeans, hogs" cluster ................................................................ 18

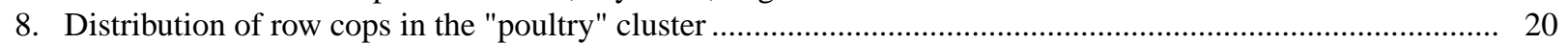

9. Distribution of orchard, vineyards, and nursery crops in the United States ............................................... 24

10. Distribution and classification of counties not initially classified by numerical criteria for orchard, vineyard, and nursery crops

. Distribution and classification of cropland and of orchard, vineyard, and nursery areas in the Lower Susquehanna River Basin

. Distribution and classification of cropland areas of the United States based on Major Land Uses of the United States and the row-crop classification system.

. Distribution and classification of cropland areas of the Lower Susquehanna River Basin based on Major Land Uses of the United States and the row-crop classification system..... 


\section{TABLES}

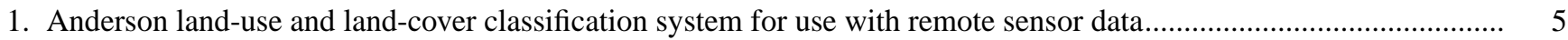

2. Row crop census data codes and national harvested area used to develop classification system ............................... 10

3. National harvested area of individual row crops in counties classified in each row crop category ............................. 35

4. National characterization of irrigation and fertilizer use and number of cattle, hogs, poultry, and turkeys within each row crop category

5. Orchard, vineyard, and nursery crops used in developing orchard, vineyard, and nursery crop categories

6. National area of orchard, vineyard, and nursery crops within each orchard, vineyard, and nursery category

CONVERSION FACTORS, VERTICAL DATUM, AND ACRONYMS

\begin{tabular}{rcl}
\hline Multiply & By & To obtain \\
\hline acre & 0.4047 & hectare \\
acre & 4,047 & square meter \\
square mile $\left(\mathrm{mi}^{2}\right)$ & 259.0 & hectare \\
square mile $\left(\mathrm{mi}^{2}\right)$ & 2.590 & square kilometer \\
& & \\
\hline
\end{tabular}

\section{Acronyms}

GIRAS, Geographic Information Retrieval and Analysis System

LULC, Land Use and Land Cover

MLU, Major Land Uses

NAWQA, National Water-Quality Assessment

USDA, U.S. Department of Agriculture

USGS, U.S. Geological Survey 


\section{Classification and Mapping of Agricultural Land for National Water-Quality Assessment}

\author{
By Robert J. Gilliom and Gail P. Thelin
}

\section{Abstract}

Agricultural land use is one of the most important influences on water quality at national and regional scales. Although there is great diversity in the character of agricultural land, variations follow regional patterns that are influenced by environmental setting and economics. These regional patterns can be characterized by the distribution of crops. A new approach to classifying and mapping agricultural land use for national water-quality assessment was developed by combining information on general land-use distribution with information on crop patterns from agricultural census data. Separate classification systems were developed for row crops and for orchards, vineyards, and nurseries. These two general categories of agricultural land are distinguished from each other in the land-use classification system used in the U.S. Geological Survey national Land Use and Land Cover database.

Classification of cropland was based on the areal extent of crops harvested. The acreage of each crop in each county was divided by total row-crop area or total orchard, vineyard, and nursery area, as appropriate, thus normalizing the crop data and making the classification independent of total cropland area. The classification system was developed using simple percentage criteria to define combinations of 1 to 3 crops that account for 50 percent or more or harvested acreage in a county. The classification system consists of 21 level I categories and 46 level II subcategories for row crops, and 26 level I categories and 19 level II subcategories for orchards, vineyards, and nurseries. All counties in the United States with reported harvested acreage are classified in these categories. The distribution of agricultural land within each county, however, must be evaluated on the basis of general land-use data. This can be done at the national scale using "Major Land Uses of the United States," at the regional scale using data from the national Land Use and Land Cover database, or at smaller scales using locally available data.

\section{INTRODUCTION}

The U.S. Geological Survey's (USGS) National Water-Quality Assessment (NAWQA) Program is designed to describe the status and trends in the quality of the nation's ground- and surface-water resources and to link the status and trends with an understanding of the natural and human factors that affect the quality of water. The program integrates information about water quality at a wide range of spatial scales, from local to national, and focuses on water-quality conditions that affect large areas of the nation or occur frequently within small areas (Hirsch and others, 1988).

The building blocks of the NAWQA Program are Study-Unit investigations, which will be conducted in 60 major hydrologic basins (Study Units) of the nation (fig. 1). The Study-Unit investigations consist of intensive assessment activity for 3 years, followed by 6 years of less intensive monitoring, with the cycle repeated perennially (Leahy and others, 1990). Twenty Study Units will be in an intensive data-collection and analysis phase during each particular year, and the first complete cycle of intensive investigations of all 60 Study Units will be completed in 2002. The 60 NAWQA Study Units cover about one-half of the conterminous United States, encompass 60-70 percent 


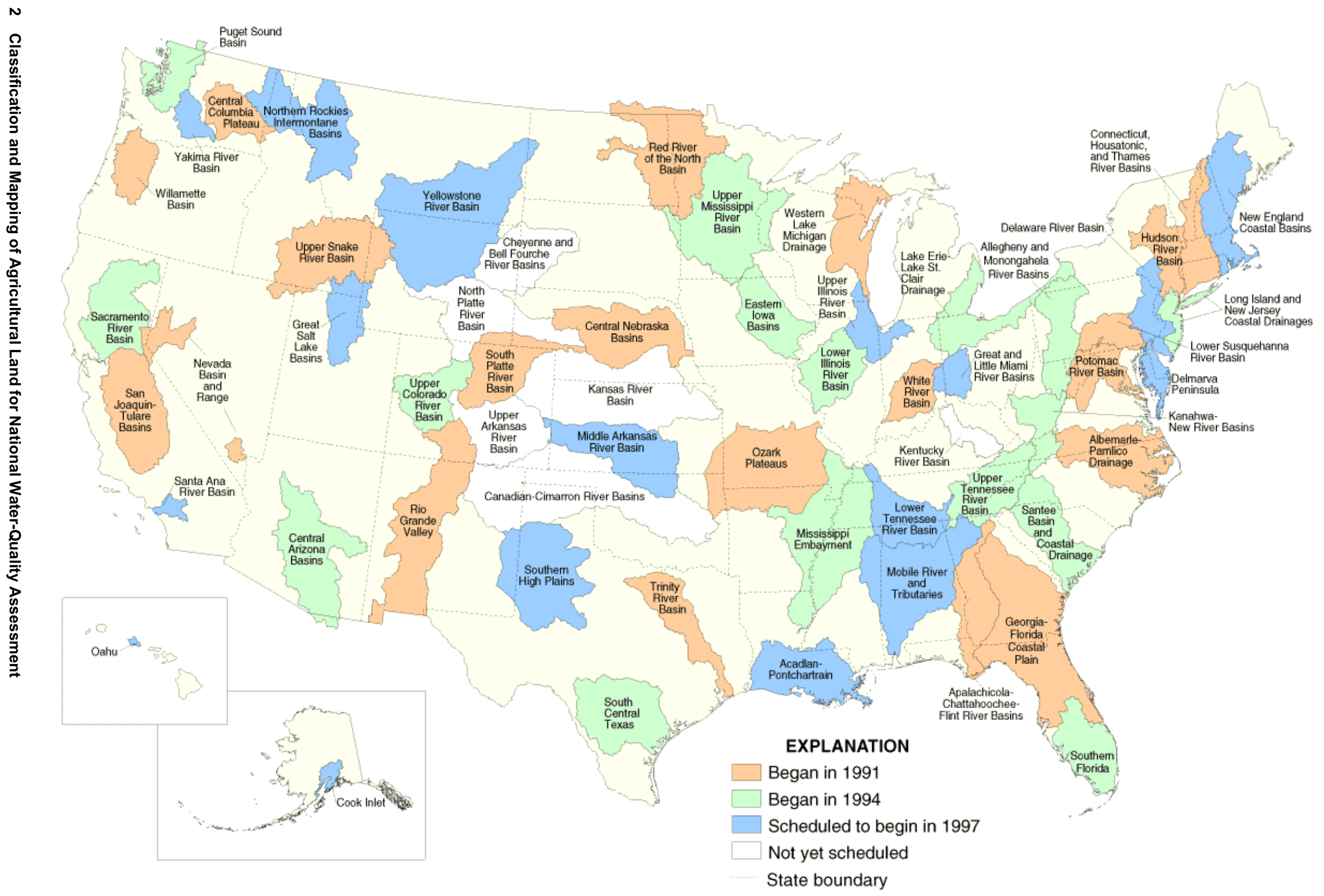

Figure 1. - Study Units of the National Water-Quality Assessment. 
of national water use and of the population served by public water supplies, and include diverse hydrologic systems that differ widely in the natural and human factors that affect water quality.

The distribution of Study Units ensures that the most important regional and national water-quality issues can be addressed by comparative studies among Study Units. NAWQA National Synthesis projects combine results of Study Unit Investigations with existing information from other programs and studies of the USGS and other agencies and researchers to produce regional and national-scale assessments for priority water-quality issues. The first water-quality issues to be focused on for National Synthesis are nutrients and pesticides.

Comparative studies among study units and national or regional aggregations of data for National Synthesis require consistent data on factors that affect the sources, behavior, and effects of contaminants and other factors that determine water-quality conditions. Natural features, such as geology, and factors related to human activities, such as land-use distribution, provide an environmental framework for assessing influences on water quality in different hydrologic systems. The emphasis of NAWQA on large-scale water-quality issues affected by human activities makes land-use characterization one of the most important aspects in study design and in the analysis of causes of waterquality conditions. Land-use characterization based on a nationally consistent classification system provides a basis for comparing the influences of human activities among Study Units. It also serves as a framework upon which to add many other types of county-based data on human activities, such as waste discharge or chemical use, that are associated with land use.

The purpose of this paper is to describe a system for classifying agricultural land for national waterquality assessment. The system focuses on classification of agricultural land within the 48 contiguous states. Alaska and Hawaii were included in basic data analysis but omitted from classification results because of their unique characteristics. Agricultural land use is one of the most important influences on water quality at national and regional scales, particularly in relation to the first NAWQA National Synthesis topics, nutrients and pesticides. Considered nationwide, agricultural land has large areal extent, a high degree of land disturbance, and high use of agricultural chemicals and water. Individual areas of agricultural land, however, can vary widely in their characteristics. There is a great diversity of agricultural activities in the nation, which follow distinct regional patterns influenced by environmental setting and economics (Sommer and Hines, 1991). Different mixes of agricultural activities characteristic of particular regions can have widely varying influences on water quality because of differences in management practices and natural environmental setting.

\section{CLASSIFYING AGRICULTURAL LAND FOR NATIONAL WATER- QUALITY ASSESSMENT}

Classification and characterization of agricultural land use for national water-quality assessment requires a balance among attributes that often conflict. The primary criteria that governed the development of the classification system described in this circular are summarized below:

1. Relevance to Management Practices Agricultural land-use categories should be defined with the greatest possible relevance to evaluating water-quality effects in relation to management practices, such as irrigation and chemical use. Categories need to be defined specifically enough that the linkage between regional water-quality effects and management practices can be evaluated.

2. Appropriate Scale - Categories must be either regionally or nationally significant in their extent, and thus have large contiguous areas that can be isolated as distinct land uses that can be focused upon for surface- and ground-water studies. Comparative studies of agricultural areas for national water-quality assessment will involve areas ranging widely in size, but most typically 100-10,000 square miles. Many of the most important comparative assessments, however, will be based on studies of areas of less than 1,000 square miles and categories must be defined specifically enough that important distinctions at this scale are evident.

3. Transferability Among Scales - Definitions and criteria for agricultural land-use categories should be suitable for making consistent and comparable classifications over a broad range of scales, using data of varying spatial resolution.

4. Stability Over Time - Criteria for defining categories should remain consistent over time 
to facilitate comparison to historical records and to enable updates to reflect new information and support future comparisons.

5. Practicality - The classification system must be applicable to any part of the nation, using available data that are nationally consistent and sufficiently up-to-date to reflect presentday land-use conditions.

\section{EXISTING CLASSIFICATION SYSTEMS AND DATA SOURCES}

Two general types of classification systems and associated geographic data are available for characterizing agricultural land uses: (1) General land-use and land-cover classifications mapped from areal photography and remotely sensed data, and (2) agricultural activities and production statistics gathered in farm-by-farm censuses and surveys. General land-use and land-cover maps have the advantage of showing the actual geographic or spatial distribution of general categories of agricultural land in relation to other land uses, irrespective of political boundaries, but have the disadvantage of not being specific on such information as crop types and management practices. Classification of agricultural land use based on activities and production statistics from the national Census of Agriculture (U.S. Department of Agriculture, 1950) or similar data presents the opposite problems. The basic census unit is generally the county or census tract, and the distribution of land uses within the unit is not addressed. However, the activities and production statistics are very detailed on such factors as the total area of each crop harvested within a county, the number of poultry or livestock, irrigation, chemical and fertilizer expenses, and many other features potentially important for water-quality assessment.

\section{General Land-Use Classification}

The highest resolution, nationally consistent classification of land use and land cover currently available for the United States is the U.S. Geological Survey Land Use and Land Cover (LULC) data stored in the Geographic Information Retrieval and Analysis System (GIRAS). The national LULC data were compiled primarily from color-infrared aerial photography acquired during the mid-1970's (Anderson and others, 1976). From this photography, polygons of land use and land cover were manually interpreted and delineated on 1:250,000-scale maps, and in a few cases, 1:100,000-scale maps for the entire United States. Land cover classes were based on Anderson's "Land Use and Land Cover Classification System for Use with Remote Sensor Data" (Anderson and others, 1976). The Anderson classification system is a twolevel hierarchy (table 1). The minimum mapping unit for the national LULC data is 10 acres for urban uses, as well as for some other categories such as confined feeding operations and strip mines, and 40 acres for all other classes. Land-use maps have been digitized for most of the nation and are available as digital files. An example of LULC data for the Lower Susquehanna NAWQA Study Unit is shown in figure 2.

The U.S. Geological Survey national LULC data have adequate spatial resolution for regional waterquality assessment in most parts of the nation. Its primary disadvantages for water-quality assessment are: (1) lack of specificity on land-use characteristics, such as dominant crops grown and irrigation, (2) it is almost 20 years old, and (3) it is difficult to produce comparable updates using currently available remotesensing data.

In addition to the national LULC data stored in GIRAS, there is also a much more generalized characterization of Major Land Uses (MLU) of the United States (U.S. Geological Survey, 1970). The MLU map, which is also available in digital form, was interpreted from a variety of information sources, generally representing conditions in the 1960's. Although more general and with much lower resolution compared to the national LULC data, this characterization of major land use patterns is useful for national-scale evaluations.

\section{Agricultural Land-Use Classification}

The U.S. Department of Agriculture (USDA) has been classifying agricultural land in the United States since the early 1900 's. Studies conducted from 1908 to 1950 were generally referred to as "type of farming studies" (Spillman, 1908; Smith and others, 1916; Baker, 1921; Elliot, 1933; and U.S. Department of Agriculture, 1950). These studies generally progressed from division of the nation into 10 or 12 major agricultural provinces based upon crop or livestock dominance and physiographic conditions (Smith and others, 1916; Baker, 1921), to much more detailed subdivisions based primarily on farm income sources (Elliot, 1933; U.S. Department of Agriculture, 1950). Elliot differentiated 514 major types of farming areas 
TABLE 1. - Anderson land-use and land-cover classification system for use with remote sensor data

[Data from Anderson and others, 1976]

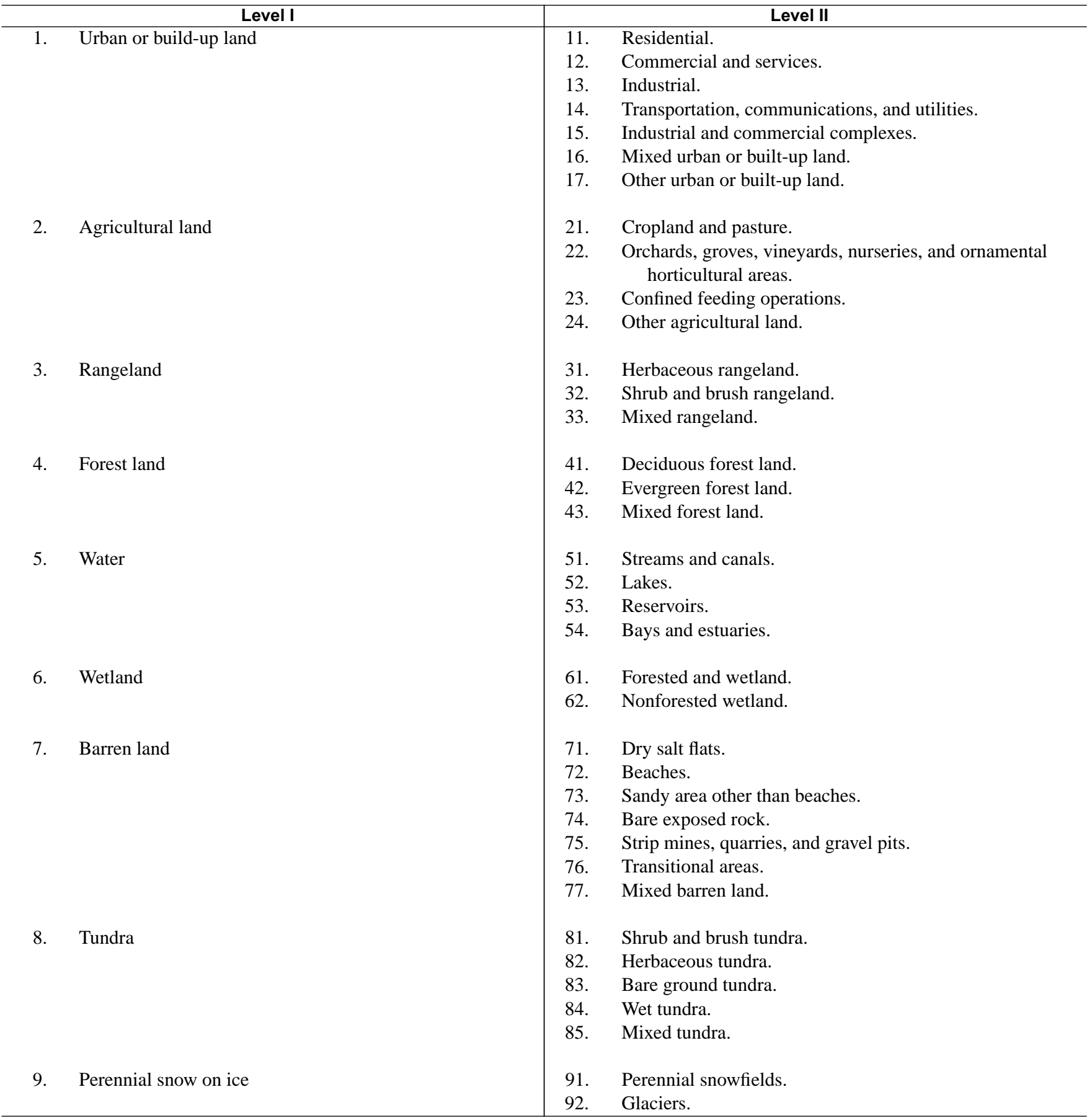

and many additional subareas, providing a very detailed interpretive view of agricultural patterns in 1930. Elliot's work was updated and generalized by U.S. Department of Agriculture (1950), resulting in 165 types of farming areas, 61 subregions, and 9 major regions. These early studies, although now out-dated in many respects, contain thorough descriptions of the environmental and economic factors that affect the distribution and nature of agriculture in different parts of the nation that are still valid today.

After many years of little activity in the area of agricultural land classification, Smith and Hines (1988) and Sommer and Hines (1991) used cluster analysis of county-based data from the 1980 Census of Population and 1987 Census of Agriculture, primarily related to farm income sources, to derive an 


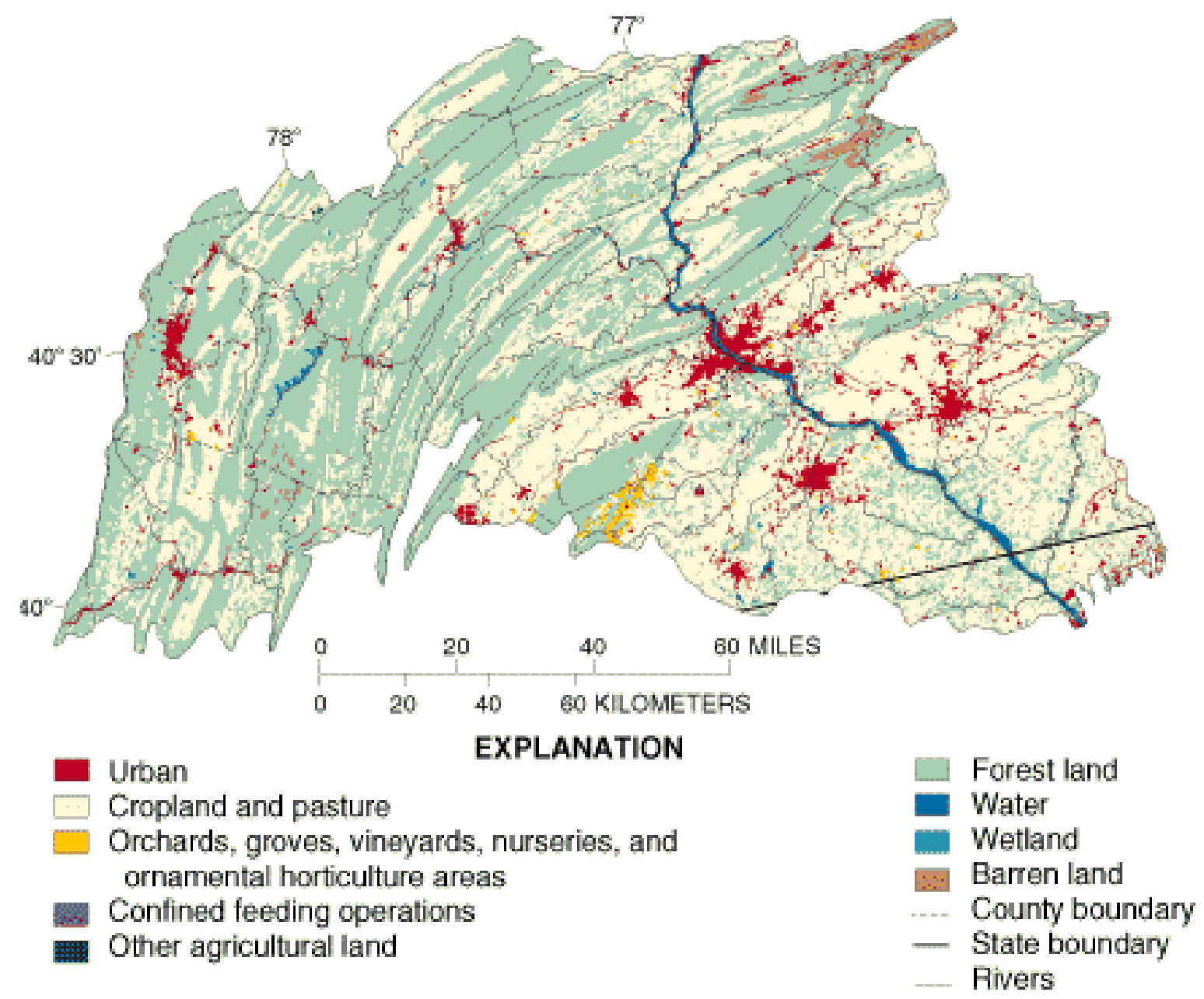

Figure 2. -General land use in the Lower Susquehanna River Basin NAWQA Study Unit based on U.S. Geological Survey National Land Use and Land Cover (LULC) data.

economics-based division of the nation into agricultural categories representing distinct farmsector characteristics. Sommer and Hines (1991) identified 12 major clusters (fig. 3) of counties with relatively similar agricultural economic environments with respect to farm enterprise, farm resources, and farm-nonfarm linkages.

With varying degrees of detail and rigor, all early and recent attempts to classify agricultural land have relied primarily on county-based data from the Census of Agriculture for characterizing crop production, income sources, expenses, and other factors. These data have the advantages of being collected regularly (currently every 5 years), and comparable at the county, state, and national levels. Primary disadvan-tages are the limitation of spatial resolution to county-aggregated statistics and, closely related, the lack of relation to the geographic areas in which the agri-cultural activities actually take place within counties.
In some respects, the agricultural classifications developed by Elliott (1933) and U.S. Department of Agriculture (1950), represent the type of classification needed for national water-quality assessment. They integrated farm income, crop dominance, and physiographic features in classifying areas and determining boundaries. A significant problem with the approach taken in these studies, however, is that the criteria and rationale for determining classes and boundaries were general and subjective, leading to an analysis that would be impossible to update over time in a comparable fashion. For example, the relative influence of variations in physiographic features and agricultural activities on these classifications is not always clear and there are few quantitative criteria used. In addition, because of the emphasis on farm income, high-income activities have a dominant influence compared to extent of land area in particular crops.

Recent efforts employing cluster analysis (Smith and Hines, 1988; Sommer and Hines, 1991; fig. 3) are 


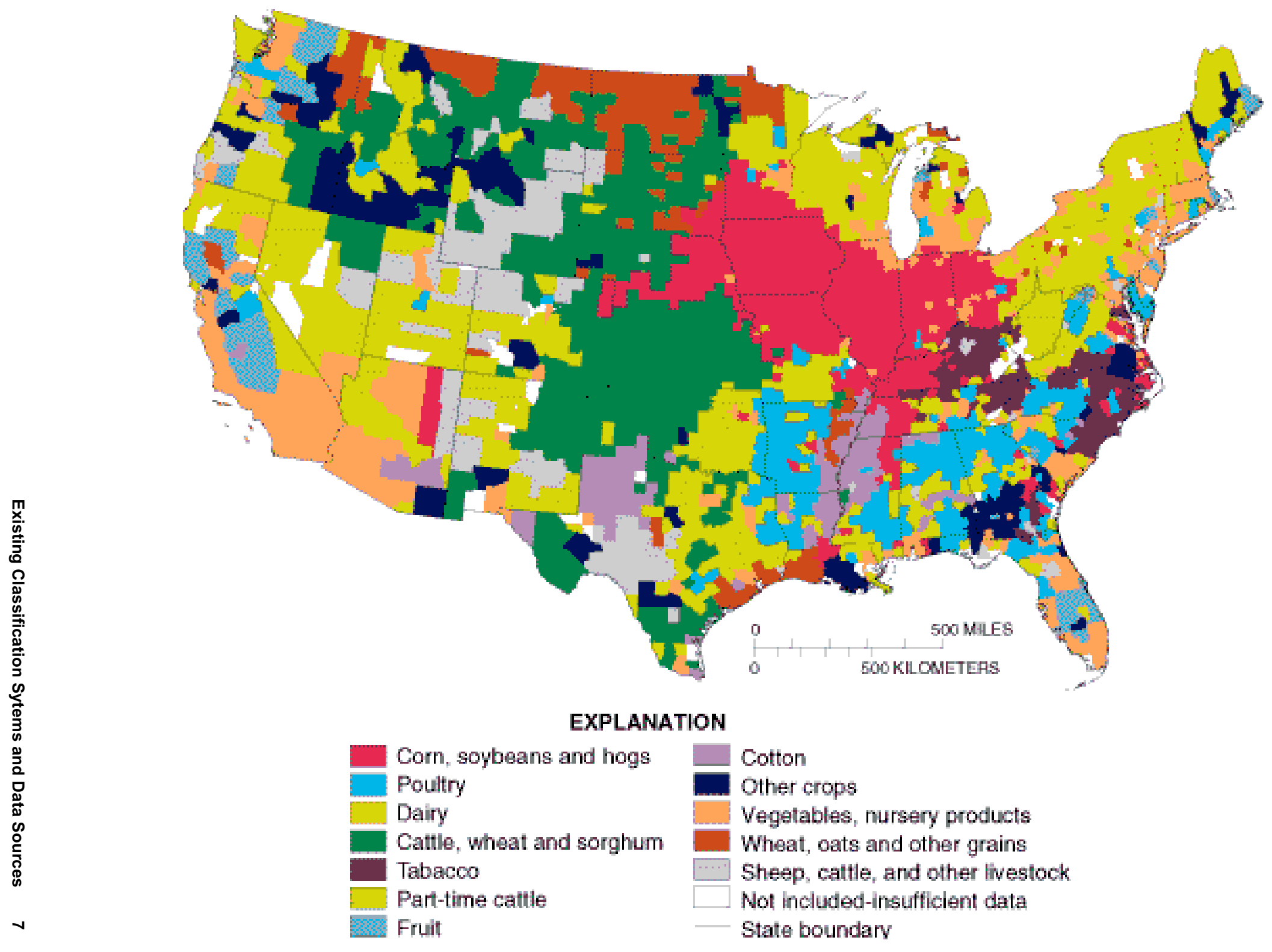

Figure 3. - Twelve multicounty clusters showing patterns of agricultural diversity in the United States (from Sommer and Hines, 1991). 
a reproducible statistical approach derived directly from Census of Agriculture data. The advantage of this approach compared to historical descriptive approaches is offset by the low resolution of the classification (12 clusters) and the problem that cluster definitions will necessarily change with the changing statistical characteristics of each new census data set. In addition, the analysis is based primarily on incomeproducing activities to emphasize economic patterns, rather than on the areal extent of agricultural land uses, which may be more important to regional water-quality conditions.

\section{CLASSIFICATION OF AGRICULTURAL LAND BY CROP DISTRIBUTION}

A new approach to classifying and mapping the distribution of agricultural land use for water-quality assessment was developed by combining the information on general land-use distribution from the U.S. Geological Survey national LULC data, based on the Anderson classification system, with the county-based agricultural census data. The LULC data is used to locate agricultural land within each county, and the classification of agricultural land in each county is determined from census data on crop distributions.

Data on harvested crops from the 1987 Census of Agriculture were used to classify agricultural land into two primary categories that correspond to the Anderson Level II categories of (1) cropland and pasture, and (2) orchards, groves, vineyards, nurseries, and ornamental horticultural areas, hereafter referred to as "orchards, vineyards, and nurseries" (table 1). Separate classification of agricultural land within these two general categories defined in the Anderson system retains an organizational link to the Anderson system and enables county-based crop statistics and classifications to be associated with actual geographic areas of agricultural land within each county. Anderson's "cropland and pasture" class includes three broad categories of agricultural land as reported in the Census of Agriculture: row crops (including alfalfa), grass hay (all hay except alfalfa), and pasture (rangeland is separate). Grass hay and pasture are widespread and are managed in a relatively similar manner among the different areas of the nation that they are grown, although irrigation is more common in some areas than others. Row crops, in contrast, include a wide variety of individual crops with strong regional tendencies and unique management requirements, including widely varying water demand, tillage, fertilizers, and pesticides. The classification systems developed focus on row crops for land in the "cropland and pasture" Anderson class and on fruit, nut, and nursery crops in the "orchards, vineyards, and nurseries" Anderson class.

Classification of crops in both row-crop areas and orchard, vineyard, and nursery areas was based on the acreage of individual crops harvested, rather than income production or a specific management characteristic, such as cultivation method or chemical use. Conceptually, the goal is for the classification of cropland in a particular county to yield a realistic depiction of the relative areal extent of dominant crops. Use of the census data on harvested acreage causes some land that is harvested more than once to be counted more than once in contributing to acreage. In this sense, the classification is based on annual average acreage of crops for an entire county, including withinyear rotation.

Classification based upon the acreage of individual crops has the advantage for water-quality studies of representing conditions prevalent for most of the land that may contribute runoff or recharge for a particular area. This approach has the potential disadvantage of not adequately accounting for small areas of specialized crops that may have unique management practices, such as heavy irrigation or chemical use, and thus a disproportionate effect on water quality. These unique situations, which are not areally extensive, are difficult to evaluate from national county-based data, and generally, any national system will need to be refined using higher resolution data in order to characterize these patterns.

The acreage of each crop in each county, as reported in the census data base, was divided by the sum of individual row-crop acreages or orchard, vineyard, and nursery acreages, as appropriate, in the county. Thus, the classification was developed based on the proportional representation of crops within rowcrop and orchard, vineyard, and nursery areas, but is independent of the total amount of row-crop or orchard, vineyard, and nursery land in the county.

Two general approaches were considered for developing the classification system from these normalized data on proportional areas of individual crops in each county. Cluster analysis was considered, but not used. The results from cluster analysis would change with different data from different census years and from different spatial scales. In addition, cluster 
definitions are interpreted general tendencies rather than clear, quantitative measures of conditions observed in the field. Furthermore, cluster analysis is well-suited to identifying relatively few broad categories of conditions and becomes subjective when used to identify minor categories, which may be very important to water-quality assessment.

The second approach considered, and the one selected, is to use simple percentage criteria to classify each county according to the proportional land area of each crop harvested. This approach has the advantages of being simple and directly related to what is observable in the field. It is also flexible in allowing identification of minor categories in a hierarchical manner without disrupting major categories. The approach is described below and the advantages and disadvantages evaluated.

\section{Row Crops}

Row crops used in developing the classification system are listed in table 2 along with 1987 Census of Agriculture (U.S. Department of Commerce, 1995) data codes and national harvested acreage. For each specific crop with a census-item number, the census contains acreage totals for counties with 10 or more farm operations from which $\$ 1,000$ of agricultural products were produced or sold during the census year. Total acreages for some crops with several subcategories, such as "corn," "wheat and other grains," and "sorghum" were summed from multiple census items for each county to simplify the number of crops to classify. The crops included in table 2 account for almost 100 percent of national cropland devoted to row crops.

Four primary crops - corn, soybeans, wheat and other grains, and alfalfa-each account for 24 to 74 million acres of harvested cropland and are grown throughout large areas of the nation to varying degrees (table 2). Most of the 12 secondary crops in table 2, as aggregated, account for about 1 to 10 million acres. Most of the secondary crops require more specialized growing conditions; tend to be more restricted to smaller regions than the primary crops; frequently are high-value cash crops within the regions that they are grown; and may require intensive chemical and fertilizer use and irrigation. Some crops, such as pineapple, were not included as secondary crops because of their small acreage. The classification process for determining categories of crops from the primary and secondary crops is hierarchical, with two primary levels.

\section{Level I}

Level I classification was evaluated for all counties with reported data in the United States (all 50 States) based on a step-wise application of percentage criteria. Counties meeting criteria for each step are removed from the data base prior to applying the next step. The general logic of the level I classification is that 1,2 , or 3 primary or secondary crops that define each category account for more than 50 percent of the harvested acreage in each county classified. Criteria for each type of category are listed in order of application below:

1. One secondary crop accounts for more than 50 percent of the harvested acreage ( 12 possible categories).

2. Three of the four primary crops each account for more than 20 percent of harvested acreage (4 possible categories).

3. Two of the four primary crops each account for more than 20 percent of harvested acreage (6 possible categories).

4. One of the four primary national crops account for more than 50 percent of harvested acreage (4 possible categories).

Two-crop categories (criterion 3), as defined, can result in the two primary crops totaling less than 50 percent of the harvested acreage. This occurred for less than 10 percent of the counties in these categories, however, and the criterion for each crop of 20 percent, rather than 25 percent, resulted in fewer unclassified counties.

As summarized in figure 4, categories were established for all of the 26 potential categories in which there were 10 or more counties. In addition, level I categories of secondary crops (step 1) were established if the total acreage of the secondary crop exceeds 50,000 acres among the counties meeting the percentage criteria for a potential category (even if there were less than 10 counties). For example, only four counties in the nation had more than 50 percent of harvested area accounted for by potatoes, but the total acreage harvested among the four counties is more than 50,000 acres and, thus, a category was created in the classification system. This minimum acreage criteria provides an arbitrary, but consistent, basis for identifying crop patterns, particularly in the western United States, that are dominant in relatively few counties, but are great in their areal extent. The result of the level I classification process is 21 categories that collectively classify 2,686 of 3,078 counties in the nation that were 
Table 2. Row crop census data codes and national harvested area used to develop classification system

[Data from 1987 Census of Agriculture]

\begin{tabular}{|c|c|c|c|c|}
\hline $\begin{array}{l}\text { Individual row crops } \\
\text { or aggregations }\end{array}$ & $\begin{array}{l}\text { Individual crops as } \\
\text { recorded in census }\end{array}$ & Census data code & $\begin{array}{l}\text { National harvest } \\
\text { (acres) }\end{array}$ & $\begin{array}{c}\text { Percentage of } \\
\text { national total for } \\
\text { row crops classi- } \\
\text { fied }\end{array}$ \\
\hline & Primal & ry crops & & \\
\hline \multirow[t]{4}{*}{ Corn } & Corn for grain or seed. . . . . . . & 2107 & $58,701,505$ & 23.05 \\
\hline & $\begin{array}{l}\text { Corn for silage or green } \\
\text { chop. }\end{array}$ & 2777 & $5,785,360$ & 2.27 \\
\hline & Popcorn................ & 2207 & 268,018 & 0.10 \\
\hline & Total corn . . . . . . . . . . . . & & $64,754,883$ & 25.42 \\
\hline \multirow[t]{15}{*}{ Wheat and other grains....... } & Wheat $\ldots \ldots \ldots \ldots \ldots \ldots$ & 2127 & $53,224,174$ & 20.90 \\
\hline & Barley ............... & 2137 & $9,178,410$ & 3.60 \\
\hline & Buckwheat ............ & 2147 & 81,206 & 0.03 \\
\hline & Emmer and spelt . . . . . . . . . & 2157 & 31,361 & 0.01 \\
\hline & Flaxseed $\ldots \ldots \ldots \ldots \ldots$ & 2167 & 429,690 & 0.17 \\
\hline & Mixed grain. . . . . . . . . . & 2177 & 2,842 & 0.00 \\
\hline & Mustard seed............ & 2187 & 19,691 & 0.01 \\
\hline & Oats $\ldots \ldots \ldots \ldots \ldots \ldots$ & 2197 & $5,981,247$ & 2.35 \\
\hline & Rye $\ldots \ldots \ldots \ldots \ldots \ldots$ & 2237 & 545,868 & 0.21 \\
\hline & Proso millet. . . . . . . . . . & 2217 & 291,845 & 0.11 \\
\hline & Small grain hay. ........... & 2737 & $3,496,166$ & 1.37 \\
\hline & Safflower.............. & 2247 & 210,629 & 0.08 \\
\hline & Triticale $\ldots \ldots \ldots \ldots \ldots \ldots$ & 2267 & 152,400 & 0.06 \\
\hline & Wild rice $\ldots \ldots \ldots \ldots \ldots \ldots$ & 2277 & 31,393 & 0.01 \\
\hline & $\begin{array}{l}\text { Total wheat and other } \\
\text { grains. }\end{array}$ & & $73,676,922$ & 28.93 \\
\hline Soybeans.......... & Soybeans............... & 2307 & $55,291,205$ & 21.71 \\
\hline \multirow[t]{2}{*}{ Alfalfa $\ldots \ldots \ldots \ldots \ldots \ldots$} & Alfalfa hay $\ldots \ldots \ldots \ldots \ldots$ & 2727 & $23,629,792$ & 9.28 \\
\hline & Total primary crop area. . . . . . & & $217,352,802$ & 85.35 \\
\hline \multicolumn{5}{|c|}{ Secondary crops } \\
\hline \multirow[t]{6}{*}{ Sorghum .............. } & Sorghum for grain or seed $\ldots$. & 2117 & $9,760,574$ & 3.83 \\
\hline & $\begin{array}{l}\text { Sorghum cut for dry forage or } \\
\text { hay. }\end{array}$ & 2787 & 101,538 & 0.04 \\
\hline & $\begin{array}{l}\text { Sorghum for silage or green } \\
\text { chop. }\end{array}$ & 2797 & 507,417 & 0.20 \\
\hline & Sorghum for sirup . . . . . . . & 3991 & 987 & 0.00 \\
\hline & Sorghum hogged or grazed. . . . . & 4001 & 13,886 & 0.01 \\
\hline & Total sorghum ........... & & $10,384,402$ & 4.08 \\
\hline Cotton . & Cotton... & 2287 & $9,826,081$ & 3.86 \\
\hline Rice...... & Rice............... & 2227 & $2,424,864$ & 0.95 \\
\hline \multirow[t]{6}{*}{ Dried beans and peas } & $\begin{array}{l}\text { Dry edible beans excluding dry } \\
\text { limas. }\end{array}$ & 2317 & $1,670,097$ & 0.66 \\
\hline & Dry lima beans ........... & 2327 & 44,423 & 0.02 \\
\hline & Dry edible beans .......... & 2337 & 232,847 & 0.09 \\
\hline & $\begin{array}{l}\text { Dry cowpeas \& dry southern } \\
\text { peas. }\end{array}$ & 2347 & 31,896 & 0.01 \\
\hline & Lentils harvested.......... & 2357 & 161,588 & 0.06 \\
\hline & Total dried beans and peas . . . . & & $2,140,851$ & 0.84 \\
\hline Sunflowers & Sunflowers $\ldots \ldots \ldots \ldots \ldots$ & 2257 & $1,982,357$ & 0.78 \\
\hline
\end{tabular}


Table 2. Row crop census data codes and national harvested area used to develop classification system-Continued

\begin{tabular}{|c|c|c|c|c|}
\hline $\begin{array}{l}\text { Individual row crops } \\
\text { or aggregations }\end{array}$ & $\begin{array}{l}\text { Individual crops as } \\
\text { recorded in census }\end{array}$ & Census data code & $\begin{array}{c}\text { National harvest } \\
\text { (acres) }\end{array}$ & $\begin{array}{l}\text { Percentage of } \\
\text { national total for } \\
\text { row crops classi- }\end{array}$ \\
\hline & & & & fied \\
\hline \multicolumn{5}{|c|}{ Secondary crops-Continued } \\
\hline Field and grass seeds & $\begin{array}{l}\text { Field seed and grass seed } \\
\text { crops. }\end{array}$ & 2457 & $1,725,743$ & 0.68 \\
\hline Peanuts................ & Peanuts for nuts . . . . . . . & 2447 & $1,436,034$ & 0.56 \\
\hline Potatoes . & Irish potatoes . . . . . . . & 2367 & $1,309,963$ & 0.51 \\
\hline \multirow[t]{3}{*}{ Sugar beets. . . . . . . . . . . . } & Sugar beets for seed. . . . . . & 2387 & 4,731 & 0.00 \\
\hline & Sugar beets for sugar. . . . . . & 2397 & $1,249,200$ & 0.50 \\
\hline & Total sugar beets ........ & & $1,253,931$ & 0.50 \\
\hline \multirow[t]{5}{*}{ Sugar cane . } & Sugar cane for seed ....... & 2407 & 43,566 & 0.02 \\
\hline & Sugar cane for sirup. . . . . . & 2417 & 27 & 0.00 \\
\hline & Sugar cane for sugar. & 2427 & 779,249 & 0.31 \\
\hline & Sugar cane not harvested... & 2437 & 95,777 & 0.04 \\
\hline & Total sugar cane ........ & & 918,619 & 0.37 \\
\hline Tobacco . . & Tobacco ............. & 2297 & 633,310 & 0.25 \\
\hline Vegetables $\ldots \ldots \ldots \ldots \ldots \ldots$ & Land used for vegetables... & 2806 & $3,264,343$ & 1.28 \\
\hline Total secondary crop area . . . . . . . . & & & $34,036,155$ & 13.37 \\
\hline $\begin{array}{l}\text { Total crop area in primary and } \\
\text { secondary crops. }\end{array}$ & & & $254,653,300$ & 100.00 \\
\hline
\end{tabular}

analyzed. The 392 counties not classified include 65 with insignificant cropland and 327 that do not fit classification criteria.

\section{Level II}

Level II subcategories were separately evaluated for all counties in each level I category. Particularly for level I categories defined by the four primary crops, which account for most of the counties classified, it is important to identify patterns in the secondary crops, which may average smaller harvested acreage, but follow strong regional patterns and have specialized management practices that may have implications for water quality.

Each county in a level I category was classified according to the secondary crop (if any) that constitutes more than 10 percent of harvested acreage. If two or more secondary crops meet the criteria (rare), the county was classified according to the crop with the greater acreage. Level II subcategories were established for 46 of 243 possible categories for which there are 10 or more counties, or for which the total acreage of the secondary crop for the particular level II subcategory exceeds 50,000 acres among the counties meeting the percentage criteria. There are as many as 8 level II subcategories for a particular level I category. A total of 867 counties were assigned to level II subcategories.

\section{Unclassified Counties}

The 327 counties not classified by the criteria defined for level I categories were assigned to the closest category by minimizing the sum of deviations from the percentage criteria for potential categories. For example, a county with 17 percent corn, 18 percent soybeans, and 47 percent wheat and other grains would be placed in the "wheat and other grains greater than 20 percent and soybeans greater than 20 percent" category because 2 percent (20-18) is less than deviations for other possibilities, such as "wheat and other grains greater than 50 percent" which has a 3 percent deviation (50-47). Reevaluation of level II subcategories, after adding the 327 formerly unclassified counties resulted in addition of four additional level II subcategories. 
One secondary crop $>50 \%$ of harvested acreage in 10 or more counties?

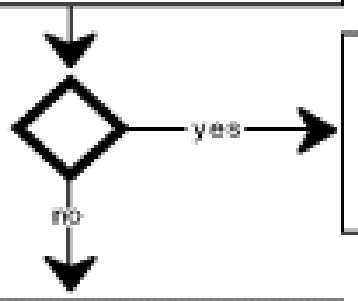

One secondary crop accounts tor $>50,000$ acres among counties where it is $>50 \%$ of harvested acreage?

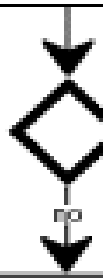

Three of four primary crops each $320 \%$ of harvested acreage in 10 or more counties?

Two of four primary crops each $>20 \%$ of harvested acreage in 10 or more counties?

Additional secondary crop $>10 \%$ of harvested acreage in 10 or more counties, or $>50,000$ acres among counties where it is $>10 \%$ of harvested acreage? yes

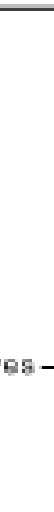

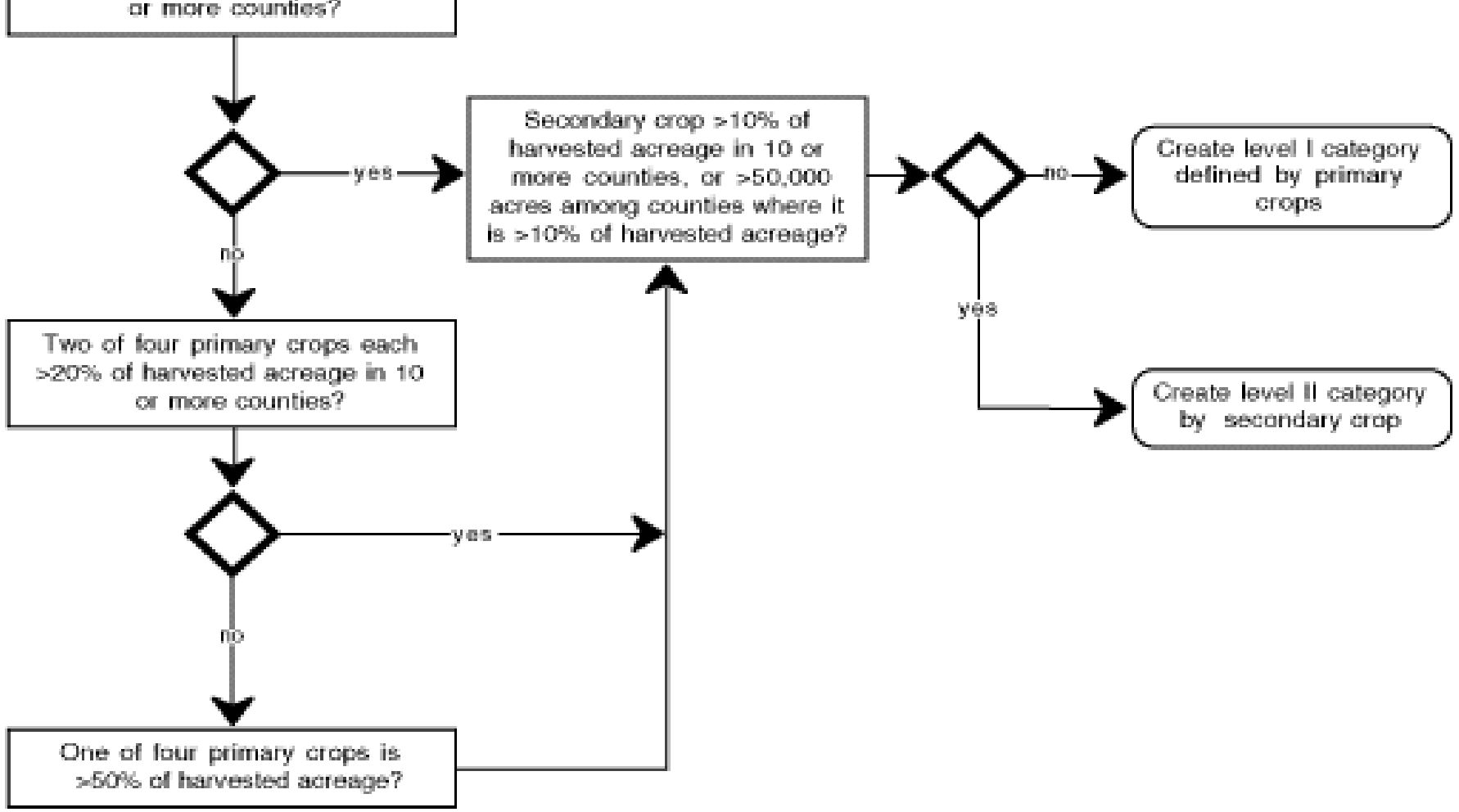
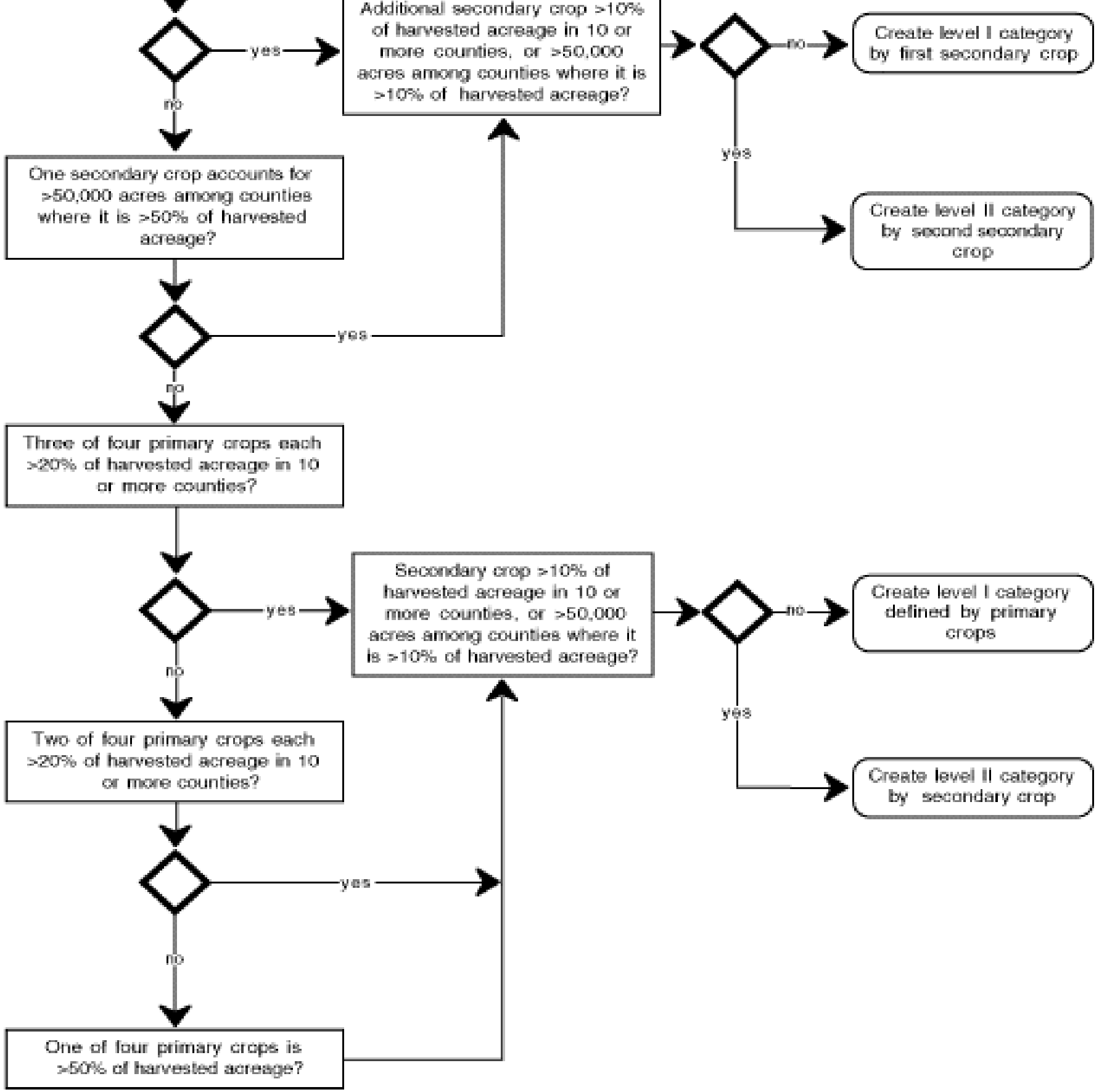

Figure 4. - Summary of decision process for creating categories for row-crop classification (>, greater than). 


\section{Results}

Results of the classification process applied to row crops in all counties in the 48 contiguous states using the 1987 Census of Agriculture data are shown in figure 5. Figure 6 shows the distribution and classification of counties that were initially not classified based on numerical criteria (these counties are also included in fig. 5). Each county is classified and colorcoded on the maps in figures 5 and 6 based on the proportional areas of harvested crops, regardless of how much row crop land use occurs in the county. The county-wide classification, therefore, must be combined with information on land-use distribution to account for the extent and geographic distribution of row crops in a particular county. Table 3 summarizes the relation of each row-crop category to national rowcrop production (see back of this circular), and table 4 to irrigation, chemical and fertilizer use, livestock, and poultry (see back of this circular).

Table 3 shows the relations among crop groups and individual crops and table 4 shows the relations among crop groups and selected indicators of agricultural management practices. For example, examination of the third column of numbers in table 3 shows that counties in the "corn and soybeans greater than 20 percent" category (not including level II subcategories) account for about 32 percent of cropland in the United States and 56 and 64 percent of corn and soybean acreage, respectively. Also evident is that counties in this crop category account for substantial amounts of the alfalfa (14.5 percent), tobacco (18.8 percent), and vegetable (13 percent) harvest. Table 4 shows that counties in the corn and soybean category account for fertilizer and chemical expenses approximately proportional to harvested acreage, but a disproportionately large share of hog production (61 percent). This agrees with the cluster analysis of Sommer and Hines (1991). In contrast, the corn and soybean category accounts for a disproportionately small proportion of irrigated land. As one example of comparative analysis, chemical expenses for "wheat and other grains greater than 50 percent" are about half as much per unit area as the "corn and soybeans" category (compare the ratio of chemical expenses to harvested acreage for each). Major variations in chemical and fertilizer expenses reflect large-scale patterns in pesticide and fertilizer use that are important to consider for water-quality assessment. These and other types of comparisons from tables 3 and 4 , combined with the map in figure 5 , can be used to evaluate the significance of individual crop categories to particular individual crops and largescale agricultural management issues.

The results of the row-crop classification are generally consistent with the cluster analysis of Sommer and Hines (1991) for their clusters dominated by individual major crops. Figure 7, for example, shows that virtually the entire area of their "corn, soybeans, hogs" cluster is classified as "corn $>20$ percent, soybeans $>20$ percent." For clusters such as "poultry", however, which are not defined primarily by crop patterns, there are a wide variety of row crop categories (fig. 8).

\section{Orchard, Vineyar d, and Nursery Crops}

Orchard, vineyard, and nursery crops used in developing the classification system are listed in table 5 with 1987 Census of Agriculture data codes and national acreages. No distinction was made between primary and secondary crops, as was done for row crops, because there are no individual orchard, vineyard, and nursery crops that are grown in large quantities over broad areas of the nation to the same degree as are corn, soybeans, wheat, and alfalfa. In addition, mixtures do not occur to the same degree because most of these crops are perennial and are not rotated like row crops. The two orchard and vineyard crops with the greatest national acreage are grapes, with about 800,000 acres, and citrus, with about 1.1 million acres. By comparison, about 74 million acres of wheat and other small grains and about 65 million acres of corn are harvested.The crops included in table 5 account for almost 100 percent of national cropland devoted to orchard, vineyard, and nursery crops, including greenhouses and sod grown for sale.

\section{Level I}

Level I classification was evaluated for all counties in the United States with reported harvest of orchard, vineyard, and nursery crops by application of percentage criteria, similar to those applied to row crops. Criteria for each type of level I category are listed below: 


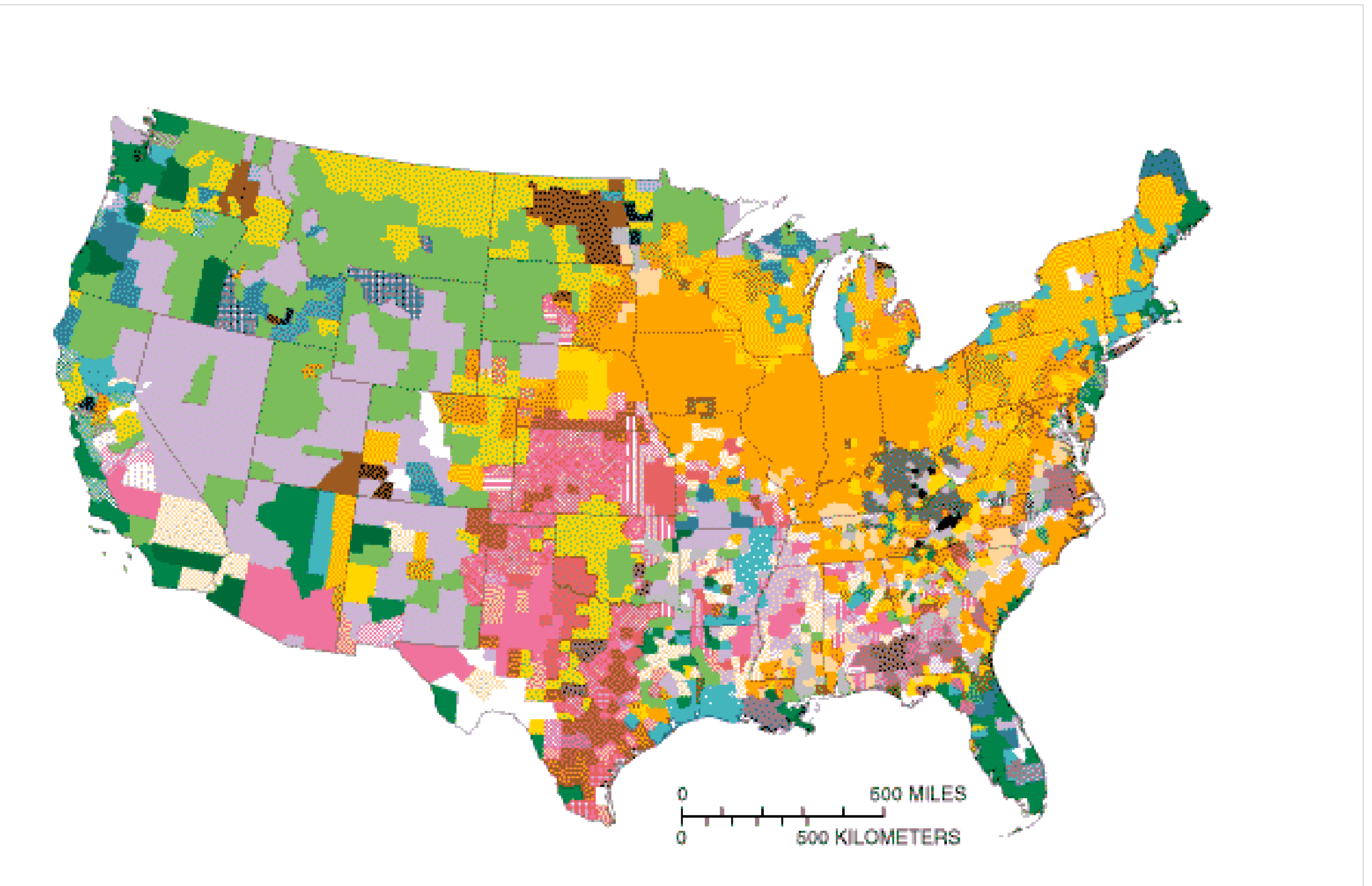

Figure 5. -Distribution of row crops in the United States. 
(All percentages are of tolal harvested acreage on a county basis:

large boxes signify lavel I categories and small boxes signify level II subcategories)

\section{Alfalfa $>50 \%$}

vegetables $>10^{\circ}$

Soybeans $>50 \%$

E cotton $>10 \%$

rice $>10 \%$

sorghum $>10 \%$

Wheat and other grains $>50 \%$

cotton $>10 \%$

dried beans and peas $>10 \%$

- field and grass seods $>10 \%$

EIII potatoes $=10 \%$

polatoes $>10 \%$

sorghum $>10 \%$

F sugar bests $>10 \%$

(2)

$\square$ Wheat and other grains $>20 \%$, Soybeans $>20 \%$

IIII) cotton $>10 \%$

Feanuts $>10 \%$

iilif sorghum $>10 \%$

IIIII tobacco $>10 \%$

Wheat and other grains $>20 \%$, Altalta $>20 \%$

cotton $>10 \%$

died beans and peas $>10 \%$

potatces $>10 \%$

sorghum $>10 \%$

IIII sugar beets $>10 \%$

vegetables $>10 \%$

Peanuts $>50 \%$

Rice $>50 \%$

Potatoes $>50 \%$

Tobacco $>50 \%$

Vegetables $>50 \%$

.

Com $>20 \%$, Alfalfa $>20 \%$, Wheat and other grains $>20 \%$

$\square$ Com $>20 \%$, Soybeans $>20 \%$, Wheat and other grains $>20 \%$

$\overrightarrow{\text { ज }}$

\section{- State boundary}

Com $>50 \%$

sorghum $>10 \%$

tobacco $>10 \%$

vegetables $>10 \%$

Com $>20 \%$, Altalfa $>20 \%$

dried beans and peas $>10 \%$

tobacco $>10 \%$

vegetables $>10 \%$

Com $>20 \%$, Soybeans $>20 \%$

cotton $>10 \%$

dried beans and peas $>10 \%$

peanuts $>10 \%$

pernuts $>10 \%$

sorghum $>10 \%$

lchaces $=10 \%$

vegetables $>10 \%$

C... Com $>20 \%$, Wheat and other grains $>20 \%$

cotton $>10 \%$

dried beans and peas $>10 \%$

peanuls $>10 \%$

sorghum $>10 \%$

tobaoco $>10 \%$

in vegetables $>10 \%$

$\therefore x_{1}, \therefore, c i n$

sorghum > $10 \%$

vegetables $>10 \%$

Sorghum $>50 \%$

cotion $>10 \%$

지라 rice $>10 \%$

Field and grass seeds $>50 \%$

vegetables $>10 \%$

Sugar Cane $>50 \%$

vegetables $>10 \%$

Counties with no

harvested acreage

of row crops

Figure 5. - Continued. 


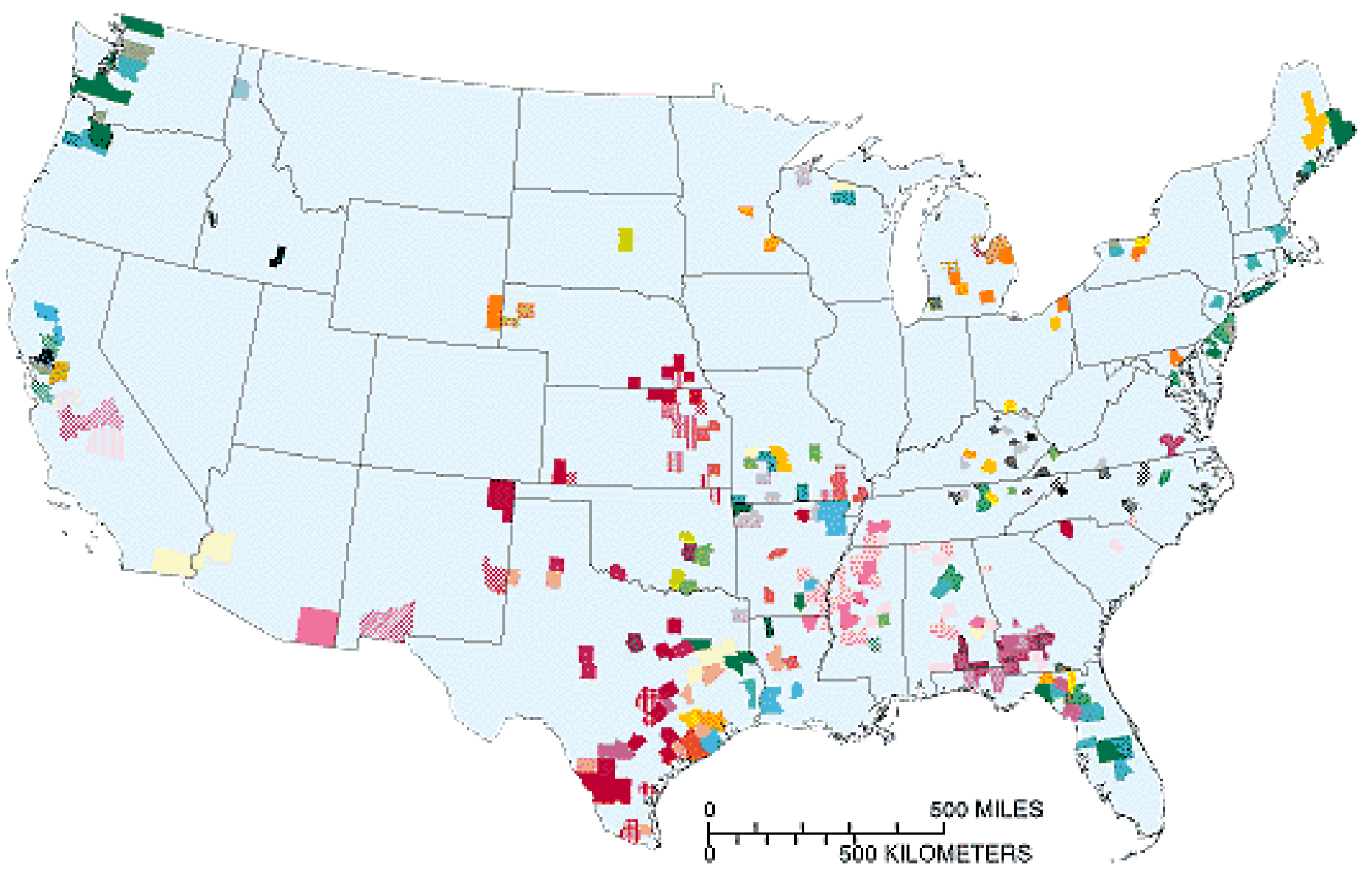

Figure 6. -Distribution and classification of counties not initially classified by numerical criteria for row crops. 


\section{EXPLANATION}

(All percentages are of total harvested acreage on a county basis:

large boxes signify level I categories and small boxes signify level II subcategories)

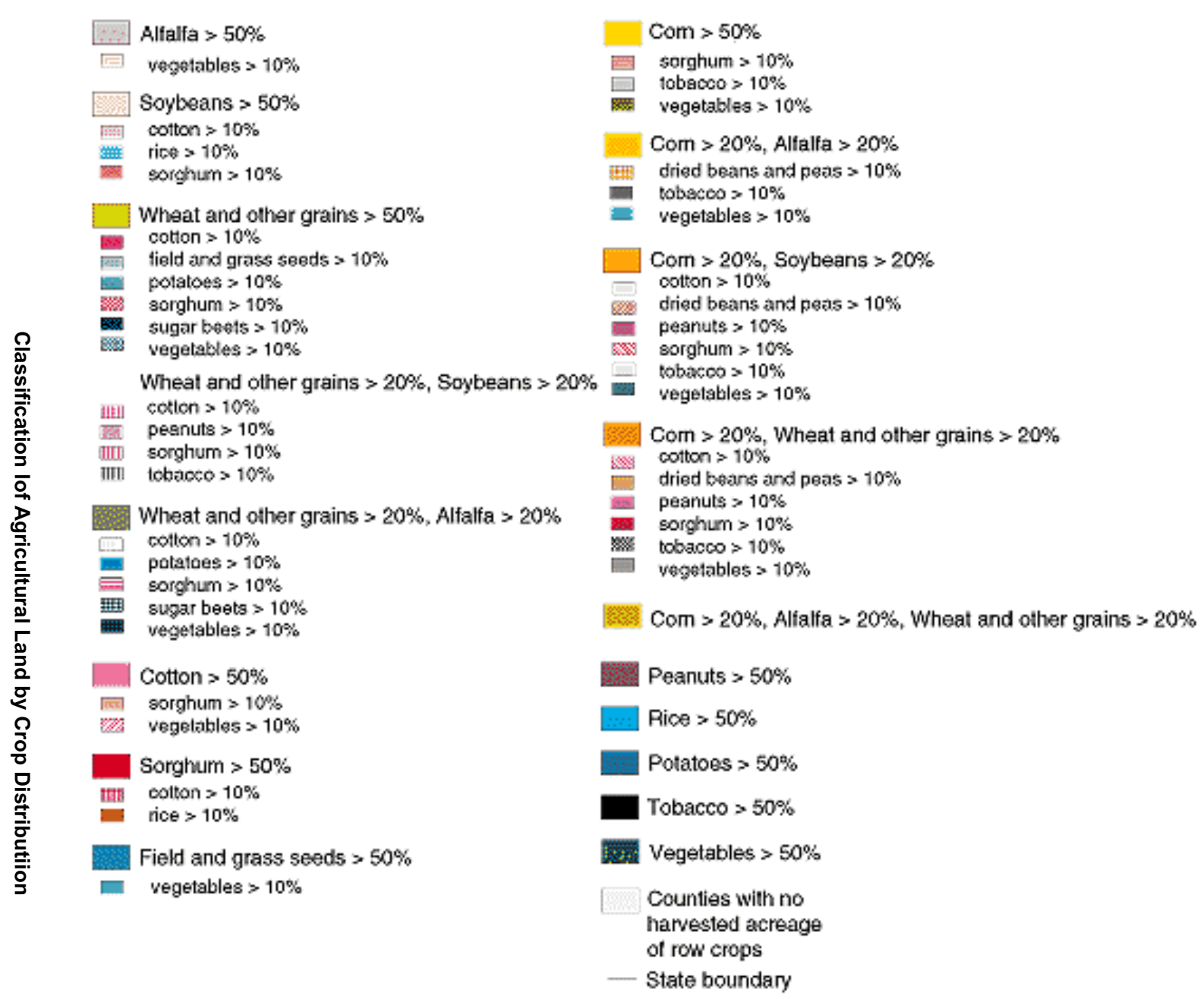

Figure 6. - Continued. 


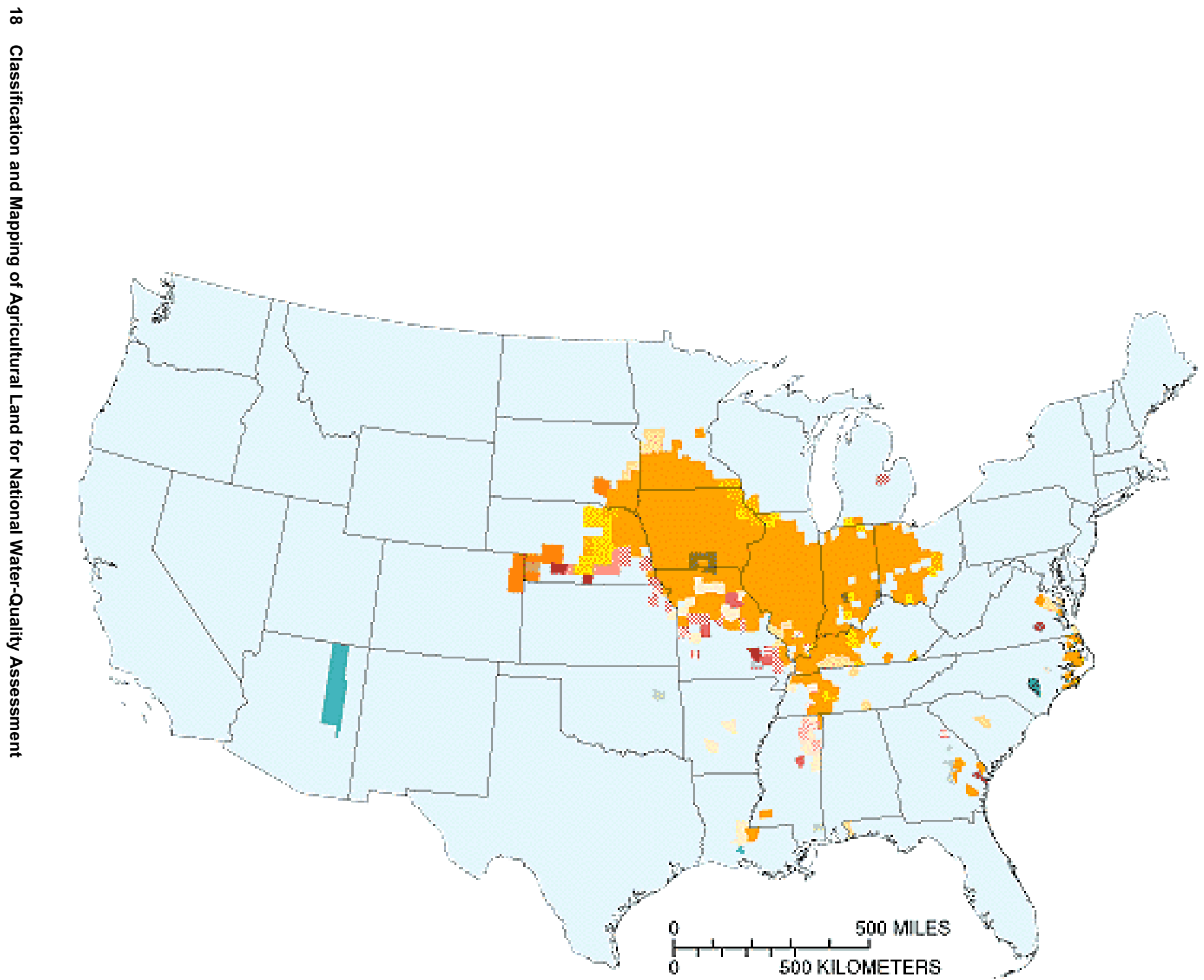

Figure 7. -Distribution of row crops in the "corn, soybeans, hogs" cluster of Sommer and Hines (1991), as shown in figure 3. 


\section{EXPLANATION}

(All percentages are of total harvested acreage on a county basis:

large boxes signify level I categories and small boxes signity level II subcategories)

Alfialfa $>50 \%$

\section{Soybeans $>50 \%$}

cotton $>10 \%$

rice $>10 \%$

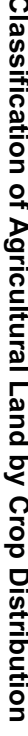

sorghum $>10 \%$

sorghum $>10 \%$ sorghum $>10 \%$

Com $>50 \%$

sorghum $>10 \%$

Com $>20 \%$, Alfalfa $>20 \%$

vegetables $>10 \%$

Com $>20 \%$, Soybeans $>20 \%$

cotton $>10 \%$

dried beans and peas $>10 \%$

peanuts $>10 \%$

sorghum $>10 \%$

tobacco $>10 \%$

vegetables $>10 \%$

Com $>20 \%$, Wheat and other grains $>20 \%$

dried beans and peas $>10 \%$

Com $>20 \%$, Soybeans $>20 \%$,

Wheat and other grains $>20 \%$

Com $>20 \%$, Alfalfa $>20 \%$,

Wheat and other grains $>20 \%$

Figure 7. -Continued. 


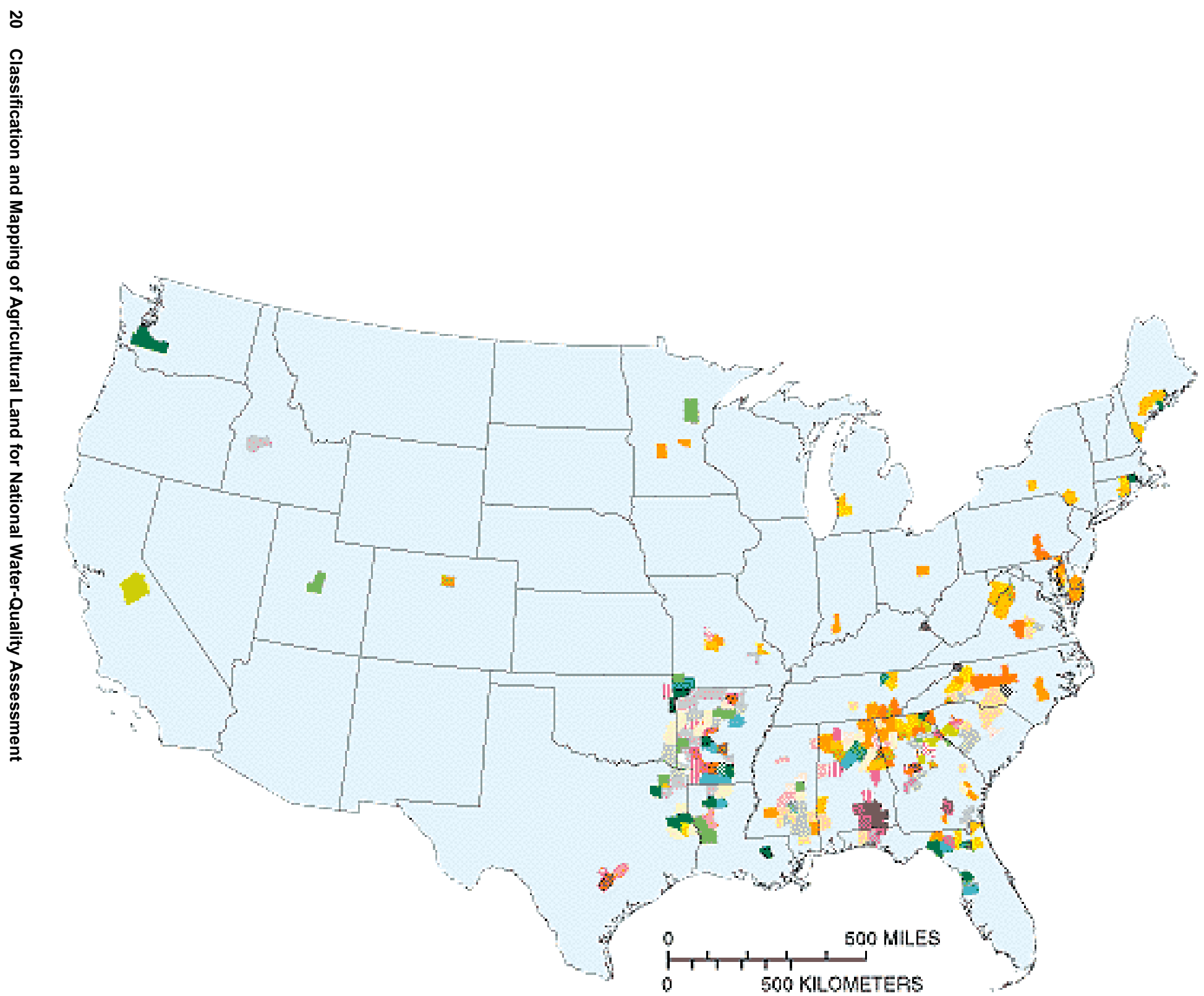

Figure 8. —Distribution of row crops in the "poultry" cluster of Sommer and Hines (1991), as shown in figure 3. 


\section{EXPLANATION}

(All percentages are of total harvested acreage on a county basis:

large boxes signify level I categories and small boxes signity level II subcategories)

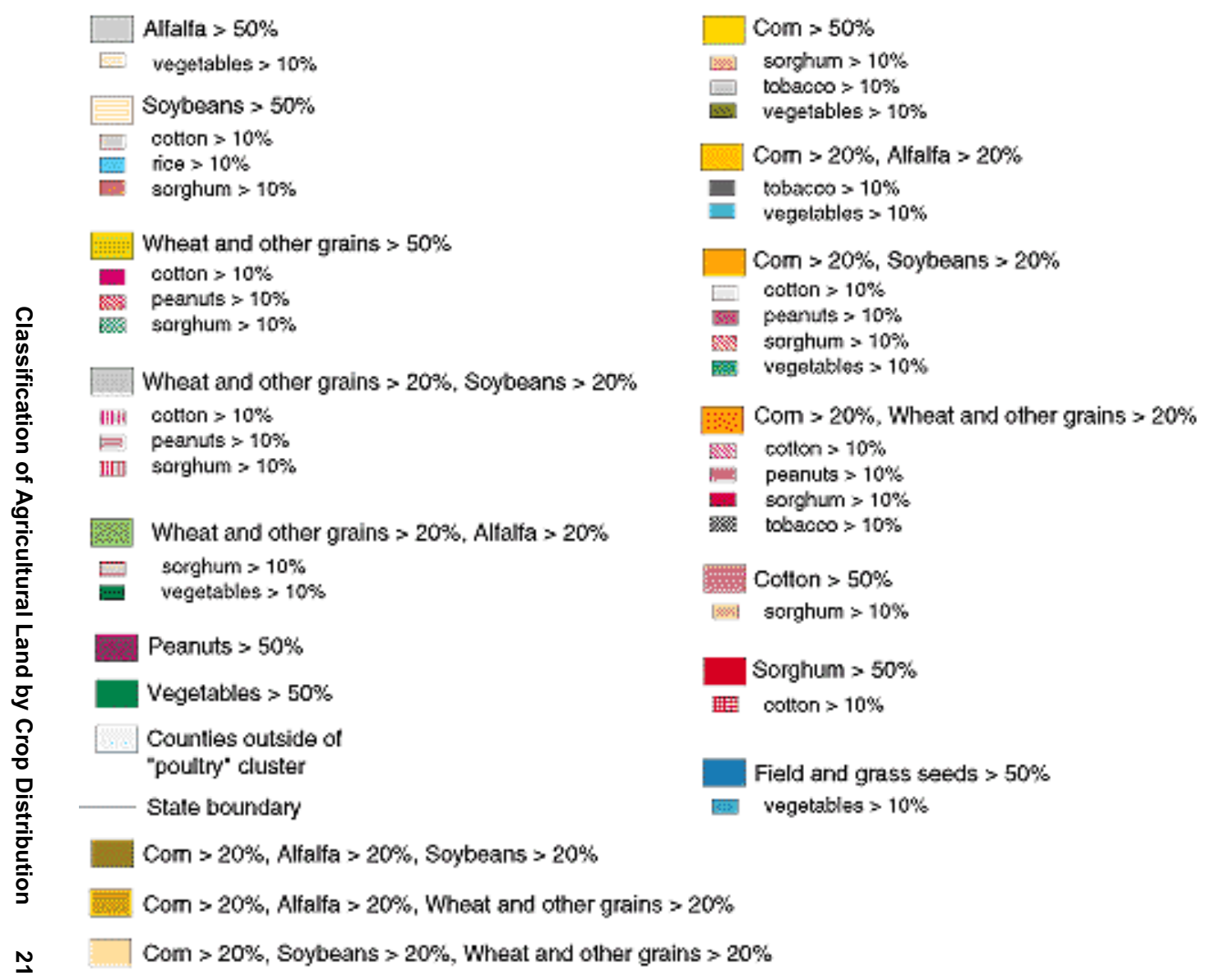

Figure 8. -Continued. 
Table 5. Orchard, vineyard, and nursery crops used in developing orchard, vineyard, and nursery crop categories

\begin{tabular}{|c|c|c|c|}
\hline $\begin{array}{l}\text { Individual orchard, vineyard, } \\
\text { and nursery crops }\end{array}$ & Census data code & $\begin{array}{l}\text { National harvest } \\
\text { (acres) }\end{array}$ & $\begin{array}{c}\text { Percentage of } \\
\text { national total for row } \\
\text { crops } \\
\text { classified }\end{array}$ \\
\hline$\overline{\text { All citrus fruit } \ldots \ldots \ldots \ldots \ldots \ldots \ldots \ldots \ldots \ldots \ldots \ldots \ldots \ldots \ldots}$ & 3457 & $1,084,504$ & 21.9 \\
\hline Grapes $\ldots \ldots \ldots \ldots \ldots \ldots \ldots \ldots \ldots \ldots \ldots$ & 3331 & 833,293 & 16.9 \\
\hline 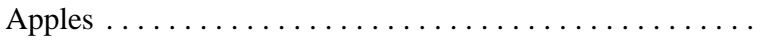 & 3232 & 601,021 & 12.2 \\
\hline $\begin{array}{l}\text { Nursery and greenhouse crops, mushrooms, and sod grown } \\
\text { for sale (greenhouses and nurseries). }\end{array}$ & 3730 & 596,382 & 12.1 \\
\hline 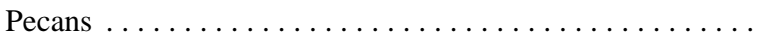 & 3574 & 453,243 & 9.2 \\
\hline 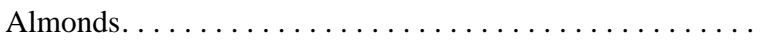 & 3547 & 427,705 & 8.7 \\
\hline 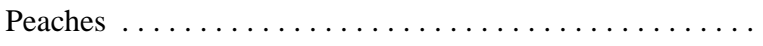 & 3403 & 239,698 & 4.9 \\
\hline English walnuts ..... & 3592 & 213,628 & 4.3 \\
\hline 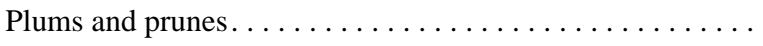 & 3430 & 151,183 & 3.1 \\
\hline$\ldots \ldots \ldots \ldots \ldots \ldots \ldots$ & 3268 & 131,064 & 2.7 \\
\hline 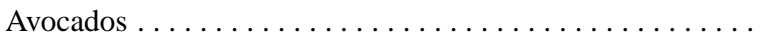 & 3250 & 87,700 & 1.8 \\
\hline Pears............ & 3412 & 84,247 & 1.7 \\
\hline Filberts and hazelnuts $\ldots \ldots \ldots \ldots \ldots \ldots \ldots \ldots$ & 3556 & 28,745 & 0.6 \\
\hline Total $\ldots \ldots \ldots \ldots \ldots \ldots \ldots \ldots \ldots \ldots$ & & $4,932,413$ & 100.0 \\
\hline
\end{tabular}

1. One crop accounts for more than 50 percent of the harvested acreage (33 possible categories).

2. Two crops each account for more than 20 percent of harvested acreage (many possible categories).

Categories were established for all potential categories of either type in which there were 10 or more counties or greater than 10,000 acres. The result of the level I classification process is 26 categories that class-ify 2,098 of 3,078 counties analyzed, with 980 counties having no reported orchard, vineyard, and nursery cropland.

\section{Level II}

Level II subcategories were separately evaluated for all counties in each level I category to further characterize the distribution of orchard, vineyard, and orchard crops. Each county in a level I category was classified according to a second crop (or third) that constitutes more than 10 percent of harvested acreage (if there is a crop exceeding 10 percent). This process resulted in 19 level II subcategories with 10 or more counties or that account for more than 10,000 acres. A total of 954 of the 2,098 classified counties were assigned to level II subcategories, with the remaining counties assigned to level I categories only. 


\section{Results}

Results of the classification process applied to all counties with harvested orchard, vineyard, and nursery crops are shown in figure 9 . Figure 10 shows the distri-bution and classification of counties that were not initially classified based on numerical criteria (these counties are also included in figure 9).

Following the procedure applied to row crops, each county is clas-sified and color coded based on the proportional area of harvested crop, regardless of how much total area is included, and must be combined with information on land-use distribution to account for the extent and geographic distribution of orchard, vine-yard, and nursery crops in a particular county. Table 6 (see back of this circular) summarizes the relation of each category of orchard, vineyard, and nursery crops to national production for all counties in each category. Results of the orchard, vineyard, and nursery crop classification cannot be directly compared to the highly aggregated clusters of Sommer and Hines (1991).

\section{APPLICATION TO LAND-USE CHARACTERIZATION}

The county-based classifications of row crops and orchards, vineyards, and nurseries are combined with information on the geographic distribution of agricultural land to improve the geographic characterization of agricultural activities. An example of the application of the classification system to the U.S. Geological Survey national LULC categories for cropland and pasture and for orchards, vineyards, and nurseries, is shown in figure 11 for the Lower Susquehanna River Basin NAWQA study unit. As discussed earlier, the LULC land-use data are the highest-resolution, nationally consistent data on land use presently available for the United States. Digital maps, such as the example in figure 11, can be derived for any regional area or river basin in the nation. As improved data on general land use or cropping patterns become available, the same approach can be applied to the new data.

For evaluating national patterns in agricultural land use and cropping patterns, the LULC data is too detailed and requires vast amounts of computer disk space and processing. The more generalized and lowerresolution map of "Major Land Uses of the United States" is used to show broad national and regional patterns (U.S. Geological Survey, 1970). Even though this major land uses map is now three decades out of date, general patterns at this scale have been relatively stable. Figure 12 (see page 32 of this circular) shows the national analysis of agricultural land use derived from the national extent of cropland and the countybased row-crop classification (fig. 5). Compared to figure 5, in which the distribution of crops is based on counties, the map of classified cropland areas in figure 12 provides an improved geographic view of the nature and distribution of cropping patterns in the United States. The more generalized nature and lower resolution of the major land uses map compared to the LULC data is shown by the comparison of figures 11 and 13 (see page 34 of this circular).

The classification system developed can potentially be used to evaluate long-term trends in cropping patterns by applying the system to past and future Census of Agriculture data, and to evaluate relations between chemical use (or other management practices) and regional crop patterns by correlating data on these practices with the crop categories. These and other applications will be explored in future investigations of specific water-quality issues. 


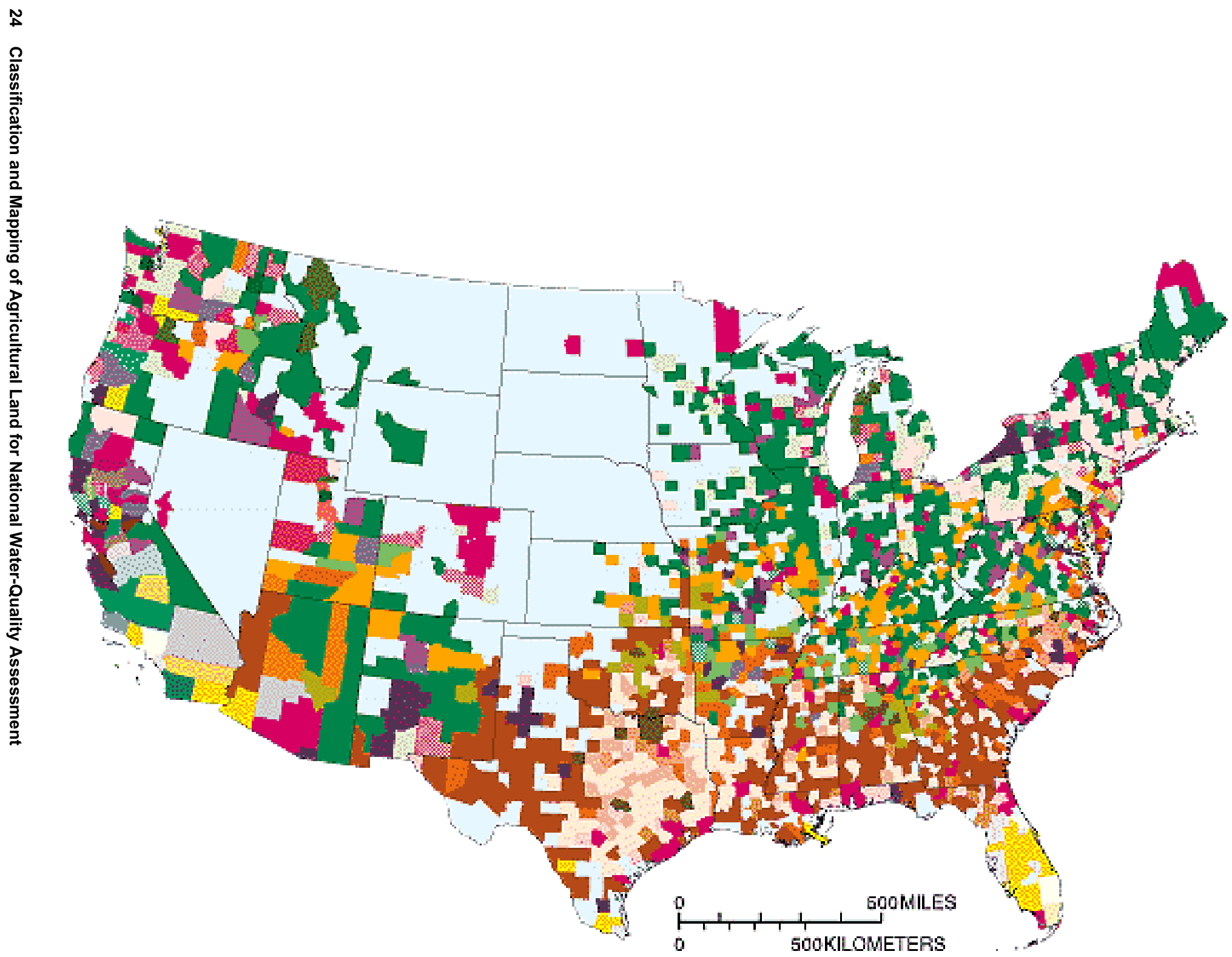

Figure 9. -Distribution of orchard, vineyards, and nursery crops in the United States. 


\section{EXPLANATION}

(All percentages are of total harvested acreage on a county basis: large boxes signify level I categories and small boxes signify level II subcategories)

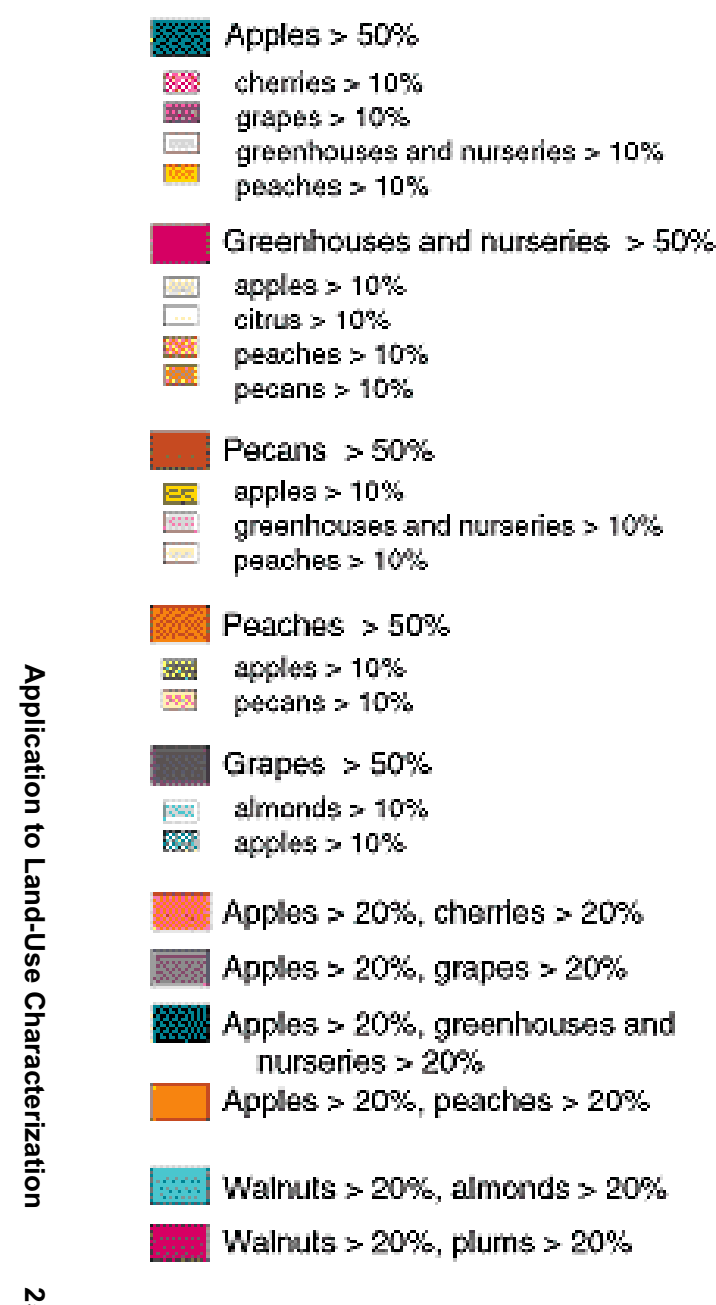

กั
Walnuts $>50 \%$

IIII) pears $>10 \%$

Cherries $>50 \%$

閣 apples $>10 \%$

Citus $>50 \%$

grapes $>10 \%$

greenhouses and nurseries $>10 \%$

Avocados $>50 \%$

Pears $>50 \%$

Filberts $>50 \%$

Find Almonds $>50 \%$, greenhouses and nurseries $>10 \%$

Almonds $>50 \%$, grapes $>10 \%$

Almonds $>50 \%$, walnuts $>10 \%$

Grapes $>20 \%$, almonds $>20 \%$

Grapes $>20 \%$, avocados $>20 \%$

Grapes $>20 \%$, citrus $>20 \%$

Peaches $>20 \%$, pecans $>20 \%$

Avocados $>20 \%$, citus $>20 \%$

Filberts $>20 \%$, greenhouses and nurseries $>20 \%$

$\square$ Counties with no harvested acreage of orchard, vineyard, or nursery crops

— State boundary

Figure 9. - Continued. 


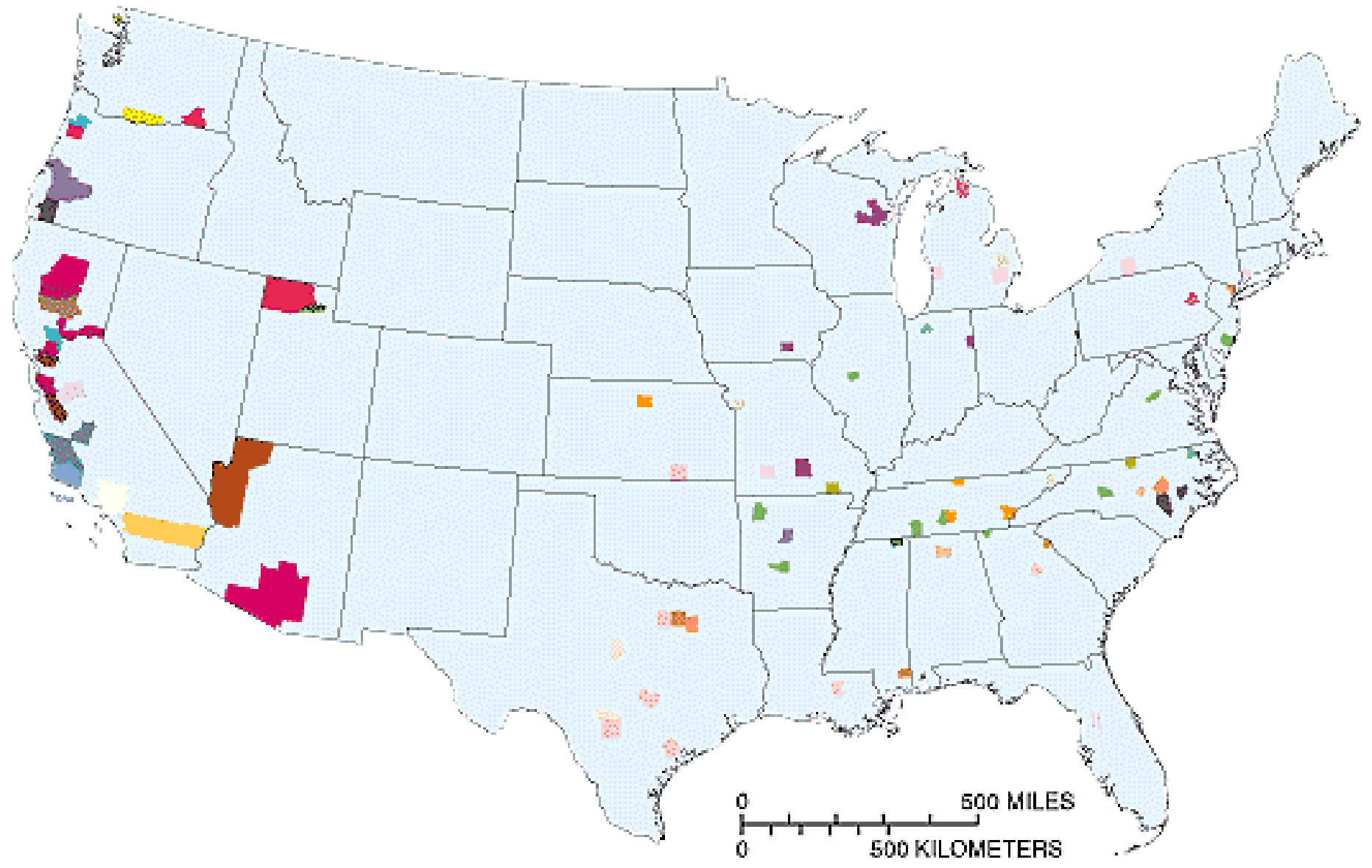

Figure 10. -Distribution and classification of counties not initially classified by numerical criteria for orchard, vineyard, and nursery crops. 


\section{EXPLANATION}

(All percentages are of total harvested acreage on a county basis:

large boxes signify level I categories and small boxes signify level II subcategories)

\section{Apples $>50 \%$}

cherries $>10 \%$

grapes $>10 \%$

greenhouses and nurseries $>10 \%$

peaches $>10 \%$

Greenhouses and nurseries $>50 \%$

apples $>10 \%$

citrus $>10 \%$

peaches $>10 \%$

pecans $>10 \%$

\section{Pecans $>50 \%$}

apples $>10 \%$

greenhouses and nurseries > $10 \%$ peaches $>10 \%$

\section{Peaches $>50 \%$}

apples $>10 \%$

pecans $>10 \%$

Grapes $>50 \%$

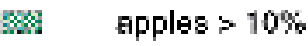

Apples $>20 \%$, Grapes $>20 \%$

Grapes $>20 \%$, Almonds $>20 \%$

Grapes $>20 \%$, Avocados $>20 \%$

Grapes $>20 \%$, Citrus $>20 \%$
Walnuts $>50 \%$

Cherries $>50 \%$

spples $>10 \%$

Citrus $>50 \%$

greenhouse and nurseries $>10 \%$

Pears $>50 \%$

Filberts $>50 \%$

Almonds $>50 \%$, Grapes $>10 \%$

Almonds $>50 \%$, Walnuts $>10 \%$

Walnuts $>20 \%$, Almonds $>20 \%$

Walnuts $>20 \%$, Plums $>20 \%$

Counties with no harvested acreage of orchard, vineyards, or nursery crops

state boundary

Figure 10. -Continued. 


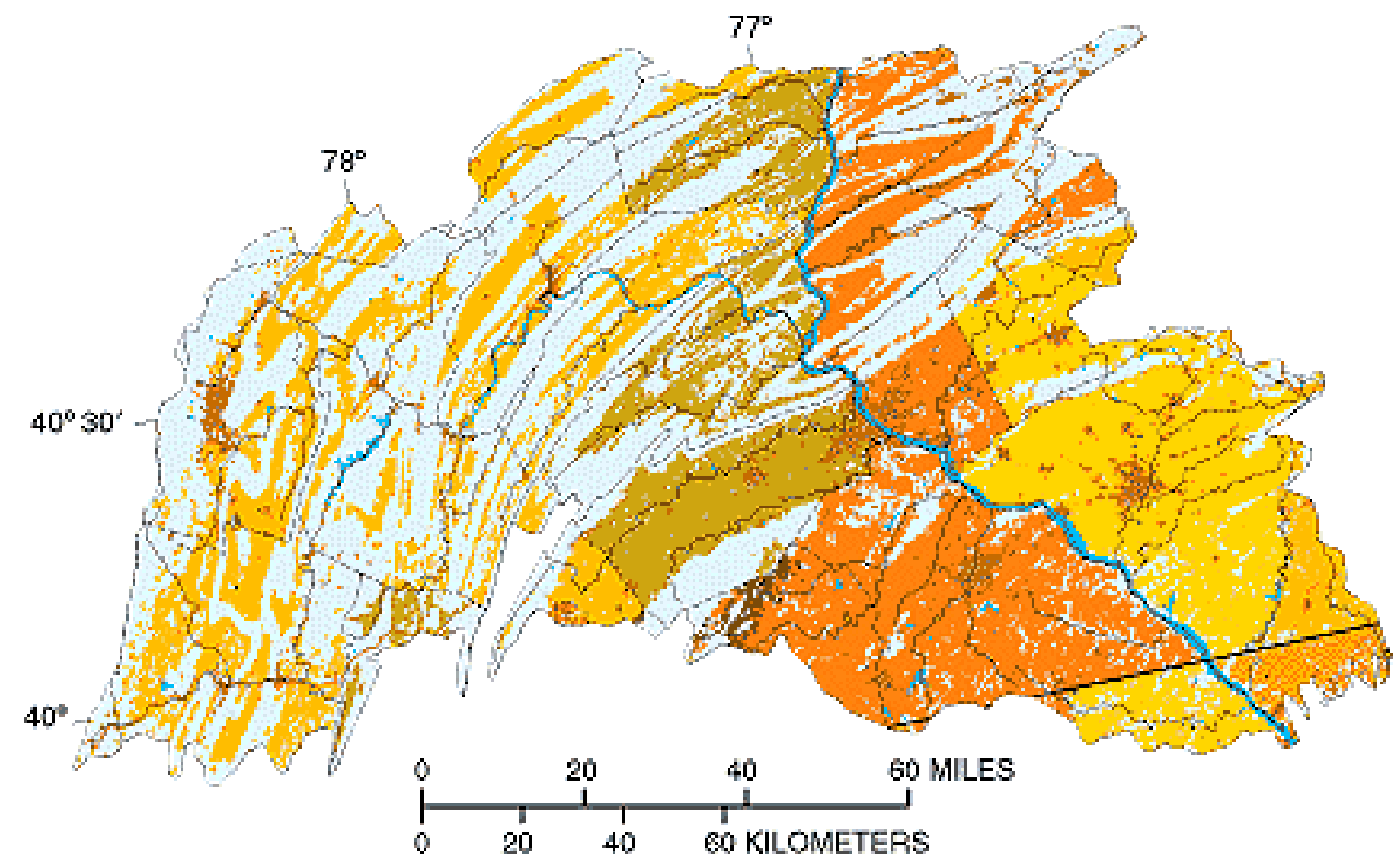

\section{EXPLANATION}

Corn $>20 \%$, alfalia $>20 \%$

Corn $>20 \%$, alfalfa $>20 \%$, wheat and other grains $>20 \%$

Corn $>20 \%$, wheat and other grains $>20 \%$

Corn $>50 \%$

Corn $>20 \%$, soybeans $>20 \%$

Urban

Water

Other land useicover

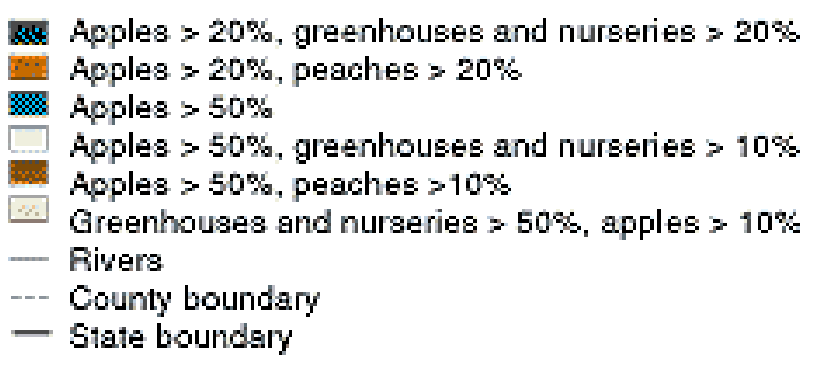

Figure 11. -Distribution and classification of cropland and of orchard, vineyard, and nursery areas in the Lower Susquehanna River Basin.

\section{SUMMARY AND CONCLUSIONS}

Agricultural land use is one of the most important influences on the water quality of the nation. Although there is great diversity in the character of agricultural land, variations follow regional patterns influenced by environmental setting and economics. These regional patterns can be characterized by the distribution of crops. A new approach to classifying and mapping agricultural land use for national waterquality assessment was developed by combining geographic information on general land-use distribution with information on crop patterns from county agricultural census data. Two separate classification systems were developed, one for row crops and another for orchards, vineyards, and nurseries. These two general types of agricultural land are distinguished from each other in the general land-use classification system of Anderson and others (1976), which was used for the U.S. Geological Survey national Land Use and Land Cover (LULC) database.

Classification of cropland was based on the areal extent of crops harvested, rather than income production or a specific management practice. The acreage of each crop in each county was divided by total row-crop area or total orchard, vineyard and nursery area, as appropriate, thus normalizing the crop data and making 
the classification independent of total cropland area. The classification system was developed using simple percentage criteria to define combinations of 1 to 3 crops that account for 50 percent or more or harvested acreage in a county.

The classification system consists of 21 level I categories and 46 level II subcategories for row crops, and 26 level I categories and 19 level II subcategories for orchards, vineyards, and nurseries. All counties in the United States with reported harvested acreage in the 1987 Census of Agriculture are classified in these categories. The distribution of agricultural land within each county, however, must be evaluated from general land-use data. This can be done at the national scale using "Major Land Uses of the United States" (U.S. Geological Survey, 1970); at the regional scale using more detailed data from the LULC database; or at smaller scales using locally available data.

The classification system has many of the attributes required for national and regional waterquality assessment, but also there are several remaining questions that need to be resolved as applications are tested. The system is discussed below in relation to the desired attributes listed at the beginning of the circular.

1. Relevance to Management Practices - The classification system is based on the assumption that management practices, such as irrigation, cultivation, chemical usage, and fertilization rates are directly related to the crops grown in an area. Thus, crop mixtures are used as a proxy for the distribution of many management practices, which can be specifically evaluated for a given class either nationally or for individual areas or regions, as needed. As the system is applied to waterquality studies, this assumption will be tested.

2. Appropriate Scale - The scale of the classification is determined by choice of percentage criteria and by choice of the minimum number of counties or area required to qualify as a class. Most counties in most classes occur in relatively contiguous areas. For national and regional-scale water-quality assessment, the scale and resolution of the county-based classification is acceptable in many parts of the nation. For analysis of relations between agriculture and waterquality conditions within individual NAWQA
Study Units and other drainage basins, the classifications by county may not be detailed enough, but can be improved with local data using the same classification system.

3. Transferability Among Scales - The system developed can be applied in the same way across a wide range of scales. The county unit is arbitrary. If data are available on crop distributions at a higher resolution, such as by irrigation district, township, or drainage basin, then these areas can be classified as if they were counties. Caution must be exercised, however, if areas are so small that relatively few individual fields are included. The system is based on the assumption that an area classified is large enough to include representation, at the time data on crops were collected, of the proportional role of individual crops in typical rotation schemes.

4. Stability Over Time - Percentage criteria, based on proportional areas, yield a simple classification system that will not change with changing time periods unless data analysts choose to make changes. Multivariate statistical methods, such as cluster analysis, yield different definitions of clusters, or classes, with any major change in data.

5. Practicality - The classification system developed can be readily applied using existing data. Suitable existing data include consistent, nationally available data (Census of Agriculture and GIRAS) and similar locally available data with higher resolution. Crop statistics are regularly updated at national, state, and county levels by various agencies, and the Census of Agriculture is conducted every five years. Land-use data, such as GIRAS, are not regularly updated at the present time. A major effort is now underway by several agencies, however, to update land-use/land-cover characterization for the nation at a resolution similar to GIRAS. The NAWQA program is participating in this effort and will be developing updated land use characterizations for all study units. 


\section{REFERENCES CITED}

Anderson, J.R., Hardy, E.E., Roach, J.T., and Witmer, R.E., 1976, A land use and land cover classification system for use with remote sensor data: U.S. Geological Survey Professional Paper 964, 28 p.

Baker, O.E., 1921, A graphic summary of American agriculture based largely on the census of 1920: U.S. Department of Agriculture, 1921 Yearbook, p. 407-506.

Elliott, F.F., 1933, Types of farming in the United States: U.S. Department of Commerce, Fifteenth census of the United States, Census of Agriculture, $225 \mathrm{p}$.

Hirsch, R.M., Alley, W.M., and Wilber, W.G., 1988, Concepts for a National Water-Quality Assessment Program: U.S. Geological Survey Circular 1021, $42 \mathrm{p}$.

Leahy, P.P., Rosenshein, J.S., and Knopman, D.S., 1990, Implementation plan for the National Water-Quality Assessment Program: U.S. Geological Survey OpenFile Report 90-174, 10 p.

Smith, Middleton, Baker, O.E., and Hainsworth, R.G., 1916, A graphic summary of American agriculture: U.S. Department of Agriculture, 1915 Yearbook, p. 329-403.
Smith, M.G., and Hines, Fred, 1988, Regional characteristics of U.S. farms and farmers in the 1980's: U.S. Department of Agriculture, Economic Research Service, Agriculture and Rural Economy Division, $28 \mathrm{p}$.

Sommer, J.E., and Hines, F.K., 1991, Diversity in U.S. agriculture - A new delineation by farming characteristics: U.S. Department of Agriculture, Economic Research Service, Agricultural Economic Report Number 646, 19 p.

Spillman, W.J., 1908, Types of farming in the United States: U.S. Department of Agriculture, Yearbook, p. 351-366.

U.S. Department of Commerce, 1995, 1992 Census of Agriculture: Washington, D.C.[CD-ROM, dBase format].

U.S. Department of Agriculture, 1950, Generalized types of farming in the United States, including a list of counties in type-of-farming regions and subregions: U.S. Department of Agriculture, Bureau of Agricultural Economics, Agriculture Information Bulletin No. 3, 35 p.

U.S. Geological Survey, 1970, The national atlas of the United States of America: Washington, D.C., United States Department of the Interior, U.S. Geological Survey, p. 158-159. 
ADDITIONAL FIGURES AND TABLES 


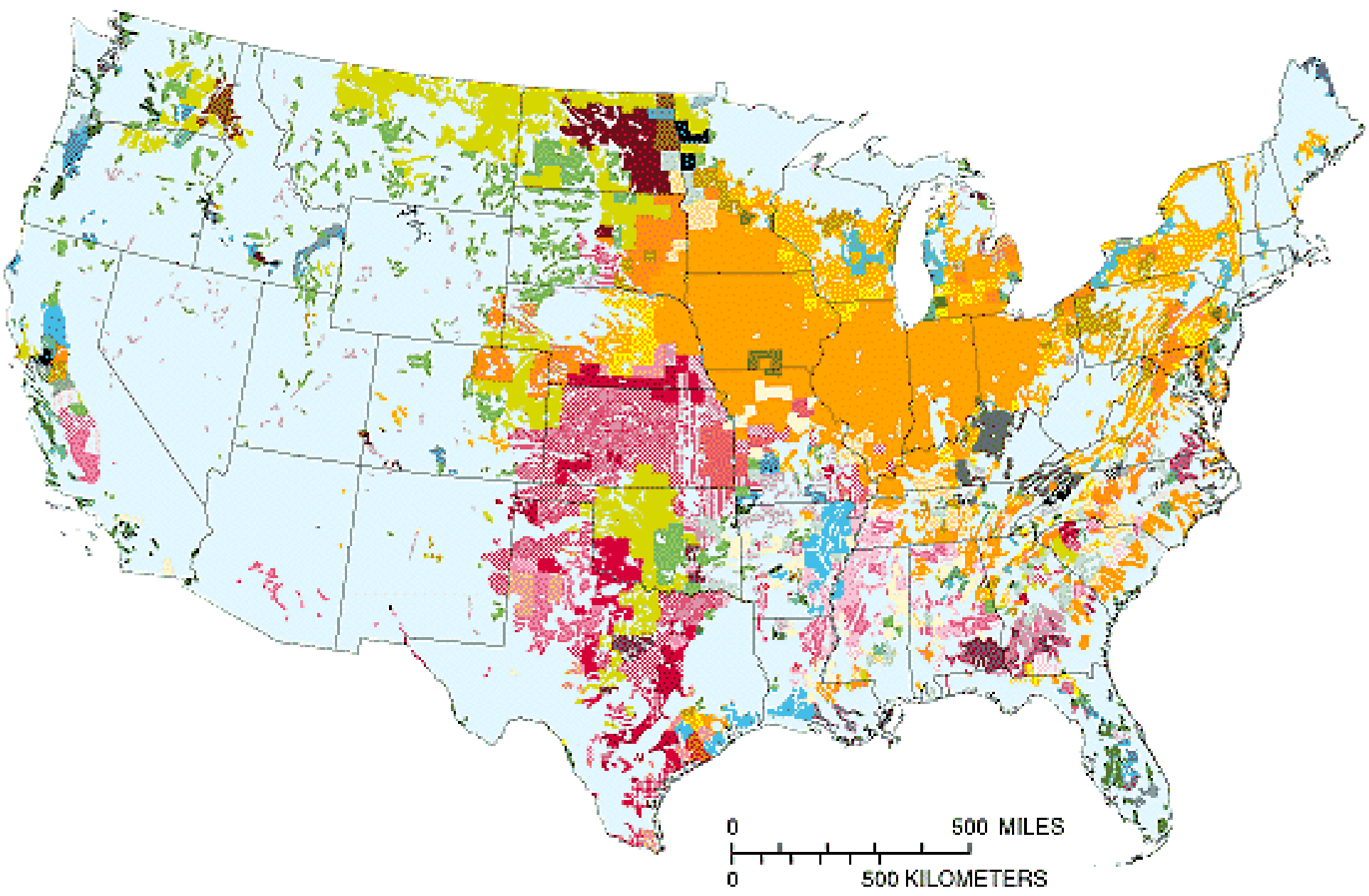

Figure 12. -Distribution and classification of cropland areas of the United States based on Major Land Uses of the United States (U.S. Geological Survey, 1970) and the row-crop classification system. 


\section{EXPLANATION}

(All percentages are of total harvested acreage on a county basis:

large boxes signify level I categories and small boxes signify level II subcategories)

Alfalta $>50 \%$

vegetables $>10 \%$

Soybeans $>50 \%$

cotton $>10 \%$

rice $>10 \%$

sorghum $>10 \%$

Wheat and other grains $>50 \%$

cotion $>10 \%$

dried beans and peas $>10^{\circ}$

field and grass seeds $>10 \%$

potatoes $>10 \%$

sorghum $>10 \%$

sugar beets $>10 \%$

sunflowers $>10 \%$

vegetables $>10^{\circ}$

Wheat and other grains $>20 \%$, Soybeans $>20 \%$

[1] cotton $>10 \%$

pesnuts $>10 \%$

III sorghum $>10 \%$

Il tobacco $>10 \%$

Wheat and other grains $>20 \%$, Altalfa $>20 \%$

cotton $>10 \%$

dried beans and peas $>10 \%$

polatoes $>10 \%$

Ex sorghum $>10 \%$

표 sugar besis $>10^{\circ}$

vegetables $>10 \%$

Sugar Cane $>60 \%$

Evgetables $>10 \%$

Peanuts $>50 \%$

Rice $>50 \%$

Potatoes $>50 \%$

Com $>20 \%$, Altalfa $>20 \%$, Soybeans $>20 \%$

Com $>20 \%$, Altalfa $>20 \%$, Wheat and other grains $>20 \%$

Com $>20 \%$. Sowbeans $>20 \%$. Wheat and other qrains $>20 \%$
Com $>50 \%$

sorghum $>10 \%$

tobacco $>10 \%$

vegetables $>10 \%$

Com $>20 \%$, Alfalfa $>20 \%$

dried beans and peas $>10 \%$

tobscco $>10 \%$

vegetables $>10 \%$

Com $>20 \%$, Soybeans $>20 \%$

colton $>10 \%$

dried beans and peas $>10 \%$

peanuts $>10 \%$

sorghum $>10 \%$

tobsceo $>10 \%$

vegetables $>10 \%$

Com $>20 \%$, Wheat and other grains $>20 \%$

cotton $>10 \%$

dried beans and pess $>10 \%$

Peanuls $>10 \%$

sorghum $>10^{\circ}$

tobacco $>10 \%$

Eegetables $>10 \%$

Cotton $>50 \%$

sorghum $>10 \%$

vegetables $>10 \%$

Sorghum $>50 \%$

entilton $>10 \%$

rice $>10 \%$

Field and grass seeds $>50 \%$

vegetables > $10^{\circ}$

Tobacoo $>50 \%$

Vegetables $>50 \%$

Counties with no

harvested acresge

of row crops

Figure 12. -Continued. 


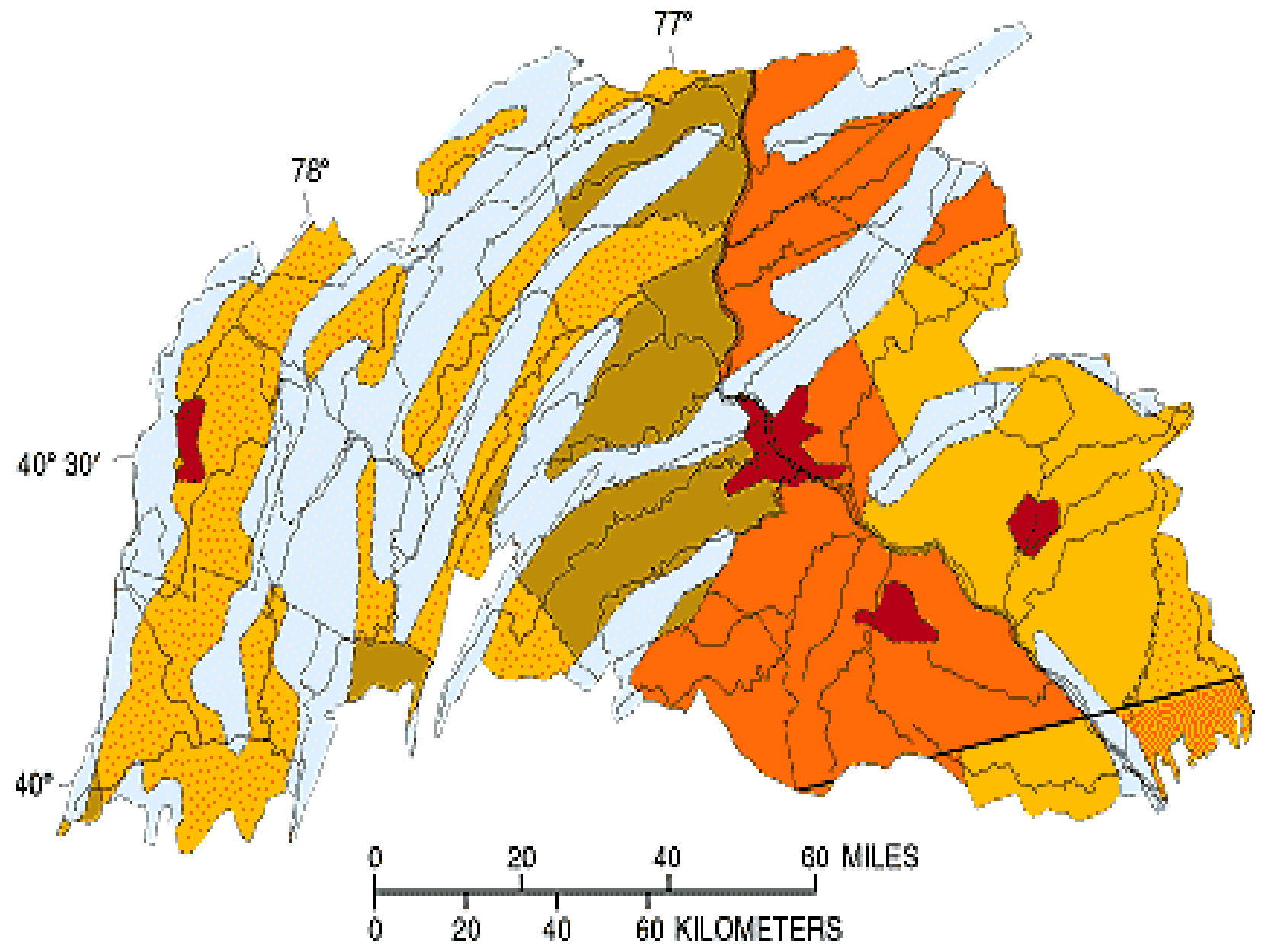

\section{EXPLANATION}

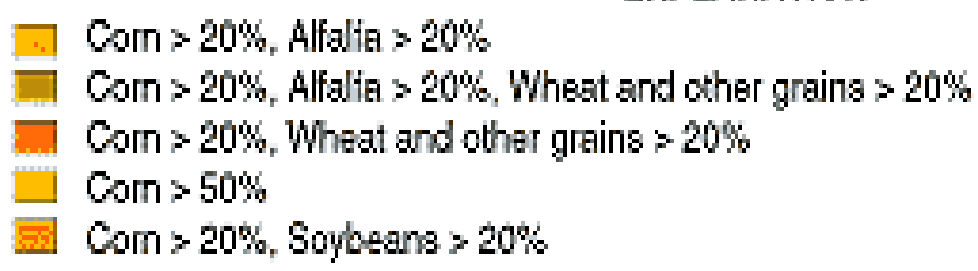

Figure 13. -Distribution and classification of cropland areas of the Lower Susquehanna River Basin based on Major Land Uses of the United States (U.S. Geological Survey, 1970) and the row-crop classification system. 
Table 3. National harvested area of individual row crops in counties classified in each row crop category [All areas are in acres. >, greater than]

\begin{tabular}{|c|c|c|c|c|c|c|c|c|}
\hline \multirow{3}{*}{ Individual row crops } & \multirow{3}{*}{$\begin{array}{l}\text { National } \\
\text { total area }\end{array}$} & \multirow{3}{*}{$\begin{array}{l}\text { Percentage of } \\
\text { national total } \\
\text { for all row } \\
\text { crops }\end{array}$} & \multicolumn{6}{|c|}{ Row crop categories } \\
\hline & & & \multicolumn{2}{|c|}{$\begin{array}{c}\text { Corn }>20 \text { percent, } \\
\text { soybeans }>20 \text { percent }\end{array}$} & \multicolumn{2}{|c|}{$\begin{array}{l}\text { Wheat and other } \\
\text { grains }>50 \text { percent }\end{array}$} & \multicolumn{2}{|c|}{$\begin{array}{l}\text { Corn }>20 \text { percent, } \\
\text { alfalfa }>20 \text { percent }\end{array}$} \\
\hline & & & $\begin{array}{l}\text { Category } \\
\text { total area }\end{array}$ & $\begin{array}{l}\text { Percentage } \\
\text { of national } \\
\text { total }\end{array}$ & $\begin{array}{l}\text { Category } \\
\text { total area }\end{array}$ & $\begin{array}{l}\text { Percentage } \\
\text { of national } \\
\text { total }\end{array}$ & $\begin{array}{l}\text { Category } \\
\text { total area }\end{array}$ & $\begin{array}{c}\text { Percentage } \\
\text { of national } \\
\text { total }\end{array}$ \\
\hline$\overline{\text { Alfalfa } \ldots \ldots \ldots \ldots \ldots}$ & $23,553,628$ & 9.3 & $3,416,442$ & 14.5 & $1,556,852$ & 6.6 & $5,165,436$ & 21.9 \\
\hline Corn .............. & $64,526,982$ & 25.5 & $36,355,081$ & 56.3 & 890,800 & 1.4 & $6,891,416$ & 10.7 \\
\hline Soybeans . . . . . . . . . . & $55,242,236$ & 21.9 & $35,128,362$ & 63.6 & 169,849 & 0.3 & 617,738 & 1.1 \\
\hline Wheat and other grains ... & $73,182,769$ & 28.9 & $5,435,876$ & 7.4 & $22,703,498$ & 31.0 & $1,757,213$ & 2.4 \\
\hline Cotton & $9,502,501$ & 3.8 & 49,418 & 0.5 & 45,437 & 0.5 & 0 & 0.0 \\
\hline Peanuts. . . . . . . . . & $1,422,254$ & 0.6 & 22,916 & 1.6 & 66,639 & 4.7 & 280 & 0.0 \\
\hline Rice $\ldots \ldots \ldots \ldots \ldots$ & $2,415,578$ & 1.0 & 10,195 & 0.4 & 0 & 0.0 & 2,767 & 0.1 \\
\hline Potatoes . . . . . . . . . & $1,229,937$ & 0.5 & 46,019 & 3.7 & 126,932 & 10.3 & 33,149 & 2.7 \\
\hline$\ldots \ldots \ldots \ldots$ & $10,228,509$ & 4.0 & 327,567 & 3.2 & 265,203 & 2.6 & 53,787 & 0.5 \\
\hline Dried beans and peas..... & $1,974,224$ & 0.8 & 54,169 & 2.7 & 197,544 & 10.0 & 51,113 & 2.6 \\
\hline Tobacco ............ & 629,787 & 0.2 & 121,403 & 19.3 & 0 & 0.0 & 28,291 & 4.5 \\
\hline Sugar cane . . . . . . . . & 831,592 & 0.3 & 11,097 & 1.3 & 0 & 0.0 & 0 & 0.0 \\
\hline Sunflowers . . . . . . . . . & $1,922,630$ & 0.8 & 792 & 0.0 & 481,034 & 25.0 & 2,281 & 0.1 \\
\hline Vegetables ........... & $3,587,220$ & 1.4 & 462,262 & 12.9 & 67,143 & 1.9 & 276,913 & 7.7 \\
\hline Field grass $\ldots \ldots \ldots \ldots$ & $1,326,555$ & 0.5 & 49,743 & 3.7 & 135,707 & 10.2 & 15,754 & 1.2 \\
\hline Sugar beets. . . . . . . . & $1,225,576$ & 0.5 & 45,527 & 3.7 & 155,872 & 12.7 & 1,450 & 0.1 \\
\hline All row crops . . . . . . . . & $252,801,978$ & 100.0 & $81,536,869$ & 32.3 & $26,862,510$ & 10.6 & $14,897,588$ & 5.9 \\
\hline
\end{tabular}


Table 3. National harvested area of individual row crops in counties classified in each row crop category-Continued

\begin{tabular}{|c|c|c|c|c|c|c|c|c|}
\hline \multirow{3}{*}{ Individual row crops } & \multicolumn{8}{|c|}{ Row crop categories } \\
\hline & \multicolumn{2}{|c|}{$\begin{array}{c}\text { Wheat and other } \\
\text { grains }>50 \text { percent, } \\
\text { sorghum }>10 \text { percent }\end{array}$} & \multicolumn{2}{|c|}{$\begin{array}{l}\text { Wheat and other } \\
\text { grains }>20 \text { percent, } \\
\text { alfalfa }>20 \text { percent }\end{array}$} & \multicolumn{2}{|c|}{$\begin{array}{c}\text { Corn }>20 \text { percent, } \\
\text { wheat and other } \\
\text { grains }>20 \text { percent }\end{array}$} & \multicolumn{2}{|c|}{$\begin{array}{c}\text { Wheat and other } \\
\text { grains }>50 \text { percent, } \\
\text { sunflowers }>10 \text { percent }\end{array}$} \\
\hline & $\begin{array}{l}\text { Category } \\
\text { total area }\end{array}$ & $\begin{array}{l}\text { Percentage of } \\
\text { national total }\end{array}$ & $\begin{array}{l}\text { Category } \\
\text { total area }\end{array}$ & $\begin{array}{l}\text { Percentage } \\
\text { of national } \\
\text { total }\end{array}$ & $\begin{array}{l}\text { Category } \\
\text { total area }\end{array}$ & $\begin{array}{c}\text { Percentage } \\
\text { of national } \\
\text { total }\end{array}$ & $\begin{array}{l}\text { Category } \\
\text { total area }\end{array}$ & $\begin{array}{l}\text { Percentage } \\
\text { of national } \\
\text { total }\end{array}$ \\
\hline 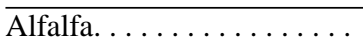 & 571,073 & 2.4 & $4,144,978$ & 17.6 & $1,018,648$ & 4.3 & 331,318 & 1.4 \\
\hline$\ldots \ldots \ldots \ldots$ & 804,031 & 1.2 & 494,227 & 0.8 & $3,096,458$ & 4.8 & 335,566 & 0.5 \\
\hline Soybeans $\ldots \ldots \ldots \ldots$ & 306,164 & 0.6 & 50,691 & 0.1 & 659,083 & 1.2 & 52,028 & 0.1 \\
\hline Wheat and other grains.... & $9,324,796$ & 12.7 & $6,348,052$ & 8.7 & $3,311,462$ & 4.5 & $4,619,530$ & 6.3 \\
\hline Cotton. . . . . . . . . . . . & 49,585 & 0.5 & 38,391 & 0.4 & 0 & 0.0 & 0 & 0.0 \\
\hline Peanuts . . . . . . . . . & 27,014 & 1.9 & 22,630 & 1.6 & 23 & 0.0 & 0 & 0.0 \\
\hline Rice $\ldots \ldots \ldots \ldots \ldots$ & 0 & 0.0 & 2,042 & 0.1 & 9,670 & 0.4 & 0 & 0.0 \\
\hline Potatoes ............ & 5,499 & 0.4 & 108,760 & 8.8 & 19,964 & 1.6 & 1,099 & 0.1 \\
\hline Sorghum . . . . . . . . . . & $3,206,260$ & 31.3 & 43,571 & 0.4 & 103,462 & 1.0 & 4,533 & 0.0 \\
\hline Dried beans and peas . . . . & 5,773 & 0.3 & 73,173 & 3.7 & 156,171 & 7.9 & 57,120 & 2.9 \\
\hline Tobacco $\ldots \ldots \ldots \ldots$ & 0 & 0.0 & 787 & 0.1 & 11,228 & 1.8 & 0 & 0.0 \\
\hline Sugar cane $\ldots . \ldots \ldots \ldots$ & 0 & 0.0 & 0 & 0.0 & 0 & 0.0 & 0 & 0.0 \\
\hline Sunflowers $\ldots \ldots \ldots \ldots$ & 56,636 & 2.9 & 86,432 & 4.5 & 111,239 & 5.8 & 960,005 & 49.9 \\
\hline Vegetables............. & 5,266 & 0.1 & 54,896 & 1.5 & 62,802 & 1.8 & 15 & 0.0 \\
\hline Field grass $\ldots \ldots \ldots \ldots$ & 10,190 & 0.8 & 181,091 & 13.7 & 37,226 & 2.8 & 2,508 & 0.2 \\
\hline Sugar beets . . . . . . . . . & 17,883 & 1.5 & 49,255 & 4.0 & 58,011 & 4.7 & 0 & 0.0 \\
\hline All row crops $\ldots \ldots \ldots \ldots$ & $14,390,170$ & 5.7 & $11,698,976$ & 4.6 & $8,655,447$ & 3.4 & $6,363,722$ & 2.5 \\
\hline
\end{tabular}


Table 3. National harvested area of individual row crops in counties classified in each row crop category—Continued

\begin{tabular}{|c|c|c|c|c|c|c|c|c|}
\hline \multirow{3}{*}{ Individual row crops } & \multicolumn{8}{|c|}{ Row crop categories } \\
\hline & \multicolumn{2}{|c|}{ Cotton $>50$ percent } & \multicolumn{2}{|c|}{ Corn $>50$ percent } & \multicolumn{2}{|c|}{$\begin{array}{c}\text { Corn }>20 \text { percent, } \\
\text { soybeans }>20 \text { percent, } \\
\text { wheat and other } \\
\text { grains }>20 \text { percent }\end{array}$} & \multicolumn{2}{|c|}{$\begin{array}{c}\text { Soybeans }>50 \text { percent, } \\
\text { cotton }>10 \text { percent }\end{array}$} \\
\hline & $\begin{array}{l}\text { Category } \\
\text { total area }\end{array}$ & $\begin{array}{l}\text { Percentage of } \\
\text { national total }\end{array}$ & $\begin{array}{l}\text { Category } \\
\text { total area }\end{array}$ & $\begin{array}{c}\text { Percentage } \\
\text { of national } \\
\text { total }\end{array}$ & $\begin{array}{l}\text { Category } \\
\text { total area }\end{array}$ & $\begin{array}{c}\text { Percentage } \\
\text { of national } \\
\text { total }\end{array}$ & $\begin{array}{l}\text { Category } \\
\text { total area }\end{array}$ & $\begin{array}{c}\text { Percentage } \\
\text { of national } \\
\text { total }\end{array}$ \\
\hline Alfalfa............. & 212,600 & 0.9 & 651,453 & 2.8 & 199,747 & 0.8 & 12,489 & 0.1 \\
\hline Corn $\ldots \ldots \ldots \ldots \ldots$ & 166,219 & 0.3 & $3,502,168$ & 5.4 & $1,508,108$ & 2.3 & 168,879 & 0.3 \\
\hline Soybeans. . . . . . . . . & 530,873 & 1.0 & 559,505 & 1.0 & $1,751,744$ & 3.2 & $2,610,372$ & 4.7 \\
\hline Wheat and other grains.... & 638,358 & 0.9 & 418,162 & 0.6 & $1,418,892$ & 1.9 & 459,488 & 0.6 \\
\hline Cotton ............. & $3,772,425$ & 39.7 & 136 & 0.0 & 8,402 & 0.1 & $1,249,692$ & 13.2 \\
\hline Peanuts $\ldots \ldots \ldots \ldots \ldots$ & 24,965 & 1.8 & 17,153 & 1.2 & 7,222 & 0.5 & 2,495 & 0.2 \\
\hline Rice $\ldots \ldots \ldots \ldots \ldots$ & 57,466 & 2.4 & 4,920 & 0.2 & 0 & 0.0 & 273,568 & 11.3 \\
\hline Potatoes ............ & 29,203 & 2.4 & 7,069 & 0.6 & 1,120 & 0.1 & 11 & 0.0 \\
\hline Sorghum & 212,149 & 2.1 & 65,153 & 0.6 & 33,067 & 0.3 & 182,688 & 1.8 \\
\hline Dried beans and peas ..... & 17,361 & 0.9 & 4,482 & 0.2 & 14,834 & 0.8 & 0 & 0.0 \\
\hline Tobacco & 0 & 0.0 & 21,642 & 3.4 & 32,498 & 5.2 & 749 & 0.1 \\
\hline Sugar cane...$\ldots \ldots \ldots$ & 0 & 0.0 & 0 & 0.0 & 0 & 0.0 & 0 & 0.0 \\
\hline Sunflowers $\ldots \ldots \ldots \ldots$ & 1,513 & 0.1 & 263 & 0.0 & 17,799 & 0.9 & 710 & 0.0 \\
\hline Vegetables............ & 96,904 & 2.7 & 77,285 & 2.2 & 22,504 & 0.6 & 7,074 & 0.2 \\
\hline Field grass $\ldots \ldots \ldots \ldots$ & 21,624 & 1.6 & 4,068 & 0.3 & 9,815 & 0.7 & 300 & 0.0 \\
\hline Sugar beets . . . . . . . . . . & 9,138 & 0.7 & 0 & 0.0 & 48,865 & 4.0 & 0 & 0.0 \\
\hline All row crops $\ldots \ldots \ldots \ldots$ & $5,790,798$ & 2.3 & $5,333,459$ & 2.1 & $5,074,617$ & 2.0 & $4,968,515$ & 2.0 \\
\hline
\end{tabular}


Table 3. National harvested area of individual row crops in counties classified in each row crop category-Continued

\begin{tabular}{|c|c|c|c|c|c|c|c|c|}
\hline \multirow{3}{*}{ Individual row crops } & \multicolumn{8}{|c|}{ Row crop categories } \\
\hline & \multicolumn{2}{|c|}{$\begin{array}{c}\text { Soybeans }>50 \text { percent, } \\
\text { rice }>10 \text { percent }\end{array}$} & \multicolumn{2}{|c|}{$\begin{array}{l}\text { Corn }>20 \text { percent, } \\
\text { alfalfa }>20 \text { percent, } \\
\text { wheat and other } \\
\text { grains }>20 \text { percent }\end{array}$} & \multicolumn{2}{|c|}{$\begin{array}{c}\text { Corn }>20 \text { percent, } \\
\text { wheat and other } \\
\text { grains }>20 \text { percent, } \\
\text { sorghum }>10 \text { percent }\end{array}$} & \multicolumn{2}{|c|}{ Soybeans $>50$ percent } \\
\hline & $\begin{array}{l}\text { Category } \\
\text { total area }\end{array}$ & $\begin{array}{l}\text { Percentage of } \\
\text { national total }\end{array}$ & $\begin{array}{l}\text { Category } \\
\text { total area }\end{array}$ & $\begin{array}{c}\text { Percentage } \\
\text { of national } \\
\text { total }\end{array}$ & $\begin{array}{l}\text { Category } \\
\text { total area }\end{array}$ & $\begin{array}{c}\text { Percentage } \\
\text { of national } \\
\text { total }\end{array}$ & $\begin{array}{l}\text { Category } \\
\text { total area }\end{array}$ & $\begin{array}{c}\text { Percentage } \\
\text { of national } \\
\text { total }\end{array}$ \\
\hline$\overline{\text { Alfalfa. . . . . . . . . . . }}$ & 5,904 & 0.0 & $1,227,722$ & 5.2 & 156,742 & 0.7 & 67,833 & 0.3 \\
\hline Corn $\ldots \ldots \ldots \ldots \ldots$ & 46,849 & 0.1 & $1,565,663$ & 2.4 & $1,062,320$ & 1.6 & 410,513 & 0.6 \\
\hline Soybeans $\ldots \ldots \ldots \ldots$ & $2,178,696$ & 3.9 & 123,373 & 0.2 & 212,556 & 0.4 & $2,524,407$ & 4.6 \\
\hline Wheat and other grains.... & 521,022 & 0.7 & $1,034,866$ & 1.4 & $1,512,317$ & 2.1 & 373,410 & 0.5 \\
\hline Cotton ............ & 235,730 & 2.5 & 0 & 0.0 & 52,191 & 0.5 & 75,983 & 0.8 \\
\hline Peanuts . . . . . . . . . & 1,338 & 0.1 & 0 & 0.0 & 28,700 & 2.0 & 3,579 & 0.3 \\
\hline Rice $\ldots \ldots \ldots \ldots \ldots$ & $1,026,638$ & 42.5 & 4,243 & 0.2 & 4,627 & 0.2 & 53,969 & 2.2 \\
\hline Potatoes $\ldots \ldots \ldots \ldots$ & 10 & 0.0 & 19,754 & 1.6 & 1,226 & 0.1 & 7,562 & 0.6 \\
\hline Sorghum............. & 223,851 & 2.2 & 30,990 & 0.3 & $1,036,953$ & 10.1 & 156,052 & 1.5 \\
\hline Dried beans and peas ..... & 0 & 0.0 & 48,644 & 2.5 & 1,833 & 0.1 & 146 & 0.0 \\
\hline Tobacco $\ldots \ldots \ldots \ldots$ & 0 & 0.0 & 3,356 & 0.5 & 0 & 0.0 & 1,231 & 0.2 \\
\hline Sugar cane...$\ldots \ldots \ldots$ & 2,107 & 0.3 & 0 & 0.0 & 0 & 0.0 & 0 & 0.0 \\
\hline Sunflowers . . . . . . . . . & 0 & 0.0 & 12,653 & 0.7 & 10,268 & 0.5 & 0 & 0.0 \\
\hline Vegetables. ........... & 4,902 & 0.1 & 105,294 & 2.9 & 9,996 & 0.3 & 27,611 & 0.8 \\
\hline Field grass $\ldots \ldots \ldots \ldots$ & 4,724 & 0.4 & 11,348 & 0.9 & 0 & 0.0 & 18,707 & 1.4 \\
\hline Sugar beets . . . . . . . . . . & 0 & 0.0 & 36,174 & 3.0 & 0 & 0.0 & 707 & 0.1 \\
\hline All row crops $\ldots \ldots \ldots \ldots$ & $4,251,771$ & 1.7 & $4,224,080$ & 1.7 & $4,089,729$ & 1.6 & $3,721,710$ & 1.5 \\
\hline
\end{tabular}


Table 3. National harvested area of individual row crops in counties classified in each row crop category-Continued

\begin{tabular}{|c|c|c|c|c|c|c|c|c|}
\hline \multirow{3}{*}{ Individual row crops } & \multicolumn{8}{|c|}{ Row crop categories } \\
\hline & \multicolumn{2}{|c|}{$\begin{array}{c}\text { Wheat and other } \\
\text { grains }>20 \text { percent, } \\
\text { soybeans }>20 \text { percent }\end{array}$} & \multicolumn{2}{|c|}{$\begin{array}{c}\text { Soybeans }>50 \text { percent, } \\
\text { sorghum }>10 \text { percent }\end{array}$} & \multicolumn{2}{|c|}{$\begin{array}{c}\text { Wheat and other } \\
\text { grains }>50 \text { percent, } \\
\text { dried beans and } \\
\text { peas }>10 \text { percent }\end{array}$} & \multicolumn{2}{|c|}{$\begin{array}{l}\text { Wheat and other } \\
\text { grains }>50 \text { percent, } \\
\text { cotton }>10 \text { percent }\end{array}$} \\
\hline & $\begin{array}{l}\text { Category } \\
\text { total area }\end{array}$ & $\begin{array}{l}\text { Percentage of } \\
\text { national total }\end{array}$ & $\begin{array}{l}\text { Category } \\
\text { total area }\end{array}$ & $\begin{array}{c}\text { Percentage } \\
\text { of national } \\
\text { total }\end{array}$ & $\begin{array}{l}\text { Category } \\
\text { total area }\end{array}$ & $\begin{array}{c}\text { Percentage } \\
\text { of national } \\
\text { total }\end{array}$ & $\begin{array}{l}\text { Category } \\
\text { total area }\end{array}$ & $\begin{array}{c}\text { Percentage } \\
\text { of national } \\
\text { total }\end{array}$ \\
\hline$\overline{\text { Alfalfa } \ldots \ldots \ldots \ldots \ldots}$ & 54,065 & 0.2 & 52,522 & 0.2 & 95,629 & 0.4 & 56,237 & 0.2 \\
\hline Corn $\ldots \ldots \ldots \ldots \ldots$ & 287,420 & 0.4 & 280,891 & 0.4 & 32,804 & 0.1 & 26,117 & 0.0 \\
\hline Soybeans . . . . . . . . . . & $1,167,549$ & 2.1 & $1,637,375$ & 3.0 & 96,068 & 0.2 & 10,785 & 0.0 \\
\hline Wheat and other grains ... & $1,275,815$ & 1.7 & 311,076 & 0.4 & $1,998,733$ & 2.7 & $1,842,629$ & 2.5 \\
\hline Cotton & 32,955 & 0.3 & 75,123 & 0.8 & 0 & 0.0 & 665,616 & 7.0 \\
\hline Peanuts. . . . . . . . . . . & 12,184 & 0.9 & 0 & 0.0 & 0 & 0.0 & 6,951 & 0.5 \\
\hline Rice $\ldots \ldots \ldots \ldots \ldots$ & 39,806 & 1.6 & 41,764 & 1.7 & 0 & 0.0 & 0 & 0.0 \\
\hline Potatoes ............ & 9,083 & 0.7 & 0 & 0.0 & 32,367 & 2.6 & 1,360 & 0.1 \\
\hline Sorghum. . . . . . . . & 42,891 & 0.4 & 621,102 & 6.1 & 0 & 0.0 & 144,540 & 1.4 \\
\hline Dried beans and peas..... & 37,446 & 1.9 & 0 & 0.0 & 485,544 & 24.6 & 65 & 0.0 \\
\hline Tobacco $\ldots \ldots \ldots \ldots \ldots$ & 8,847 & 1.4 & 0 & 0.0 & 0 & 0.0 & 0 & 0.0 \\
\hline Sugar cane . . . . . . . . . & 0 & 0.0 & 0 & 0.0 & 0 & 0.0 & 0 & 0.0 \\
\hline Sunflowers $\ldots \ldots \ldots \ldots$ & 40,272 & 2.1 & 0 & 0.0 & 59,695 & 3.1 & 0 & 0.0 \\
\hline Vegetables ........... & 37,807 & 1.1 & 2,106 & 0.1 & 15,709 & 0.4 & 2,298 & 0.1 \\
\hline Field grass $\ldots \ldots \ldots \ldots$ & 1,191 & 0.1 & 26,465 & 2.0 & 49,651 & 3.7 & 3,038 & 0.2 \\
\hline Sugar beets. . . . . . . . . . & 50,711 & 4.1 & 0 & 0.0 & 40,263 & 3.3 & 363 & 0.0 \\
\hline All row crops $\ldots \ldots \ldots$. & $3,098,042$ & 1.2 & $3,048,424$ & 1.2 & $2,906,463$ & 1.1 & $2,759,999$ & 1.1 \\
\hline
\end{tabular}


D Table 3. National harvested area of individual row crops in counties classified in each row crop category-Continued

\begin{tabular}{|c|c|c|c|c|c|c|c|c|}
\hline \multirow{3}{*}{ Individual row crops } & \multicolumn{8}{|c|}{ Row crop categories } \\
\hline & \multicolumn{2}{|c|}{$\begin{array}{c}\text { Corn }>20 \text { percent, } \\
\text { soybeans }>20 \text { percent, } \\
\text { sorghum }>10 \text { percent }\end{array}$} & \multicolumn{2}{|c|}{$\begin{array}{l}\text { Cotton }>50 \text { percent, } \\
\text { sorghum }>10 \text { percent }\end{array}$} & \multicolumn{2}{|c|}{$\begin{array}{c}\text { Wheat and other } \\
\text { grains }>20 \text { percent, } \\
\text { soybeans }>20 \text { percent, } \\
\text { sorghum }>10 \text { percent }\end{array}$} & \multicolumn{2}{|c|}{$\begin{array}{c}\text { Wheat and other } \\
\text { grains }>50 \text { percent, } \\
\text { potatoes }>10 \text { percent }\end{array}$} \\
\hline & $\begin{array}{l}\text { Category } \\
\text { total area }\end{array}$ & $\begin{array}{l}\text { Percentage of } \\
\text { national total }\end{array}$ & $\begin{array}{l}\text { Category } \\
\text { total area }\end{array}$ & $\begin{array}{c}\text { Percentage } \\
\text { of national } \\
\text { total }\end{array}$ & $\begin{array}{l}\text { Category } \\
\text { total area }\end{array}$ & $\begin{array}{l}\text { Percentage } \\
\text { of national } \\
\text { total }\end{array}$ & $\begin{array}{l}\text { Category } \\
\text { total area }\end{array}$ & $\begin{array}{c}\text { Percentage } \\
\text { of national } \\
\text { total }\end{array}$ \\
\hline$\overline{\text { Alfalfa } \ldots \ldots \ldots \ldots \ldots}$ & 83,306 & 0.4 & 20,004 & 0.1 & 126,621 & 0.5 & 175,937 & 0.7 \\
\hline Corn $\ldots \ldots \ldots \ldots \ldots$ & 750,089 & 1.2 & 109,655 & 0.2 & 124,066 & 0.2 & 14,515 & 0.0 \\
\hline Soybeans $\ldots \ldots \ldots \ldots$ & $1,035,528$ & 1.9 & 26,103 & 0.0 & 508,276 & 0.9 & 3,430 & 0.0 \\
\hline Wheat and other grains.... & 258,767 & 0.4 & 196,561 & 0.3 & 483,287 & 0.7 & $1,121,122$ & 1.5 \\
\hline Cotton $\ldots \ldots \ldots \ldots$ & 9,711 & 0.1 & $1,322,592$ & 13.9 & 7,803 & 0.1 & 0 & 0.0 \\
\hline Peanuts . . . . . . . . . . & 168 & 0.0 & 5,640 & 0.4 & 2,274 & 0.2 & 0 & 0.0 \\
\hline$\ldots \ldots \ldots \ldots \ldots \ldots$ & 21,546 & 0.9 & 11,793 & 0.5 & 9,218 & 0.4 & 0 & 0.0 \\
\hline Potatoes $\ldots \ldots \ldots \ldots$ & 0 & 0.0 & 1,923 & 0.2 & 0 & 0.0 & 314,384 & 25.6 \\
\hline Sorghum ............ & 477,818 & 4.7 & 451,964 & 4.4 & 583,495 & 5.7 & 0 & 0.0 \\
\hline Dried beans and peas ..... & 0 & 0.0 & 1,313 & 0.1 & 500 & 0.0 & 53,826 & 2.7 \\
\hline Tobacco ........... & 5 & 0.0 & 0 & 0.0 & 0 & 0.0 & 0 & 0.0 \\
\hline Sugar cane $\ldots \ldots \ldots \ldots$ & 0 & 0.0 & 6,957 & 0.8 & 0 & 0.0 & 0 & 0.0 \\
\hline Sunflowers . . . . . . . . . & 0 & 0.0 & 7,266 & 0.4 & 0 & 0.0 & 22,749 & 1.2 \\
\hline Vegetables. ............. & 1,063 & 0.0 & 15,830 & 0.4 & 2,488 & 0.1 & 6,263 & 0.2 \\
\hline Field grass $\ldots \ldots \ldots \ldots$ & 8,789 & 0.7 & 2,757 & 0.2 & 20,895 & 1.6 & 2,185 & 0.2 \\
\hline Sugar beets . . . . . . . . & 0 & 0.0 & 0 & 0.0 & 0 & 0.0 & 71,979 & 5.9 \\
\hline All row crops $\ldots . \ldots \ldots$ & $2,646,790$ & 1.0 & $2,180,358$ & 0.9 & $1,868,923$ & 0.7 & $1,786,390$ & 0.7 \\
\hline
\end{tabular}


Table 3. National harvested area of individual row crops in counties classified in each row crop category-Continued

\begin{tabular}{|c|c|c|c|c|c|c|c|c|}
\hline \multirow{3}{*}{ Individual row crops } & \multicolumn{8}{|c|}{ Row crop categories } \\
\hline & \multicolumn{2}{|c|}{ Alfalfa $>50$ percent } & \multicolumn{2}{|c|}{$\begin{array}{c}\text { Corn }>20 \text { percent, } \\
\text { soybeans }>20 \text { percent, } \\
\text { peanuts }>10 \text { percent }\end{array}$} & \multicolumn{2}{|c|}{$\begin{array}{c}\text { Corn }>20 \text { percent, } \\
\text { alfalfa }>20 \text { percent, } \\
\text { vegetables }>10 \text { percent }\end{array}$} & \multicolumn{2}{|c|}{$\begin{array}{c}\text { Wheat and other } \\
\text { grains }>50 \text { percent, } \\
\text { sugarbeets }>10 \text { percent }\end{array}$} \\
\hline & $\begin{array}{l}\text { Category } \\
\text { total area }\end{array}$ & $\begin{array}{l}\text { Percentage of } \\
\text { national total }\end{array}$ & $\begin{array}{l}\text { Category } \\
\text { total area }\end{array}$ & $\begin{array}{l}\text { Percentage } \\
\text { of national } \\
\text { total }\end{array}$ & $\begin{array}{l}\text { Category } \\
\text { total area }\end{array}$ & $\begin{array}{c}\text { Percentage } \\
\text { of national } \\
\text { total }\end{array}$ & $\begin{array}{l}\text { Category } \\
\text { total area }\end{array}$ & $\begin{array}{c}\text { Percentage } \\
\text { of national } \\
\text { total }\end{array}$ \\
\hline$\overline{\text { Alfalfa . . . . . . . . . . }}$ & $1,333,733$ & 5.7 & 4,717 & 0.0 & 391,903 & 1.7 & 62,894 & 0.3 \\
\hline Corn $\ldots \ldots \ldots \ldots \ldots$ & 81,023 & 0.1 & 442,852 & 0.7 & 621,192 & 1.0 & 78,481 & 0.1 \\
\hline Soybeans ............ & 1,875 & 0.0 & 411,902 & 0.7 & 32,090 & 0.1 & 99,977 & 0.2 \\
\hline Wheat and other grains ... & 196,109 & 0.3 & 141,698 & 0.2 & 151,104 & 0.2 & 825,491 & 1.1 \\
\hline Cotton $\ldots \ldots \ldots \ldots \ldots$ & 21,212 & 0.2 & 92,408 & 1.0 & 0 & 0.0 & 0 & 0.0 \\
\hline Peanuts. . . . . . . . . . & 0 & 0.0 & 404,914 & 28.5 & 73 & 0.0 & 0 & 0.0 \\
\hline Rice $\ldots \ldots \ldots \ldots \ldots$ & 0 & 0.0 & 0 & 0.0 & 0 & 0.0 & 0 & 0.0 \\
\hline Potatoes . . . . . . . . . & 15,791 & 1.3 & 42 & 0.0 & 52,536 & 4.3 & 44,118 & 3.6 \\
\hline Sorghum. . . . . . . . . . & 9,147 & 0.1 & 9,798 & 0.1 & 1,878 & 0.0 & 85 & 0.0 \\
\hline Dried beans and peas..... & 15,888 & 0.8 & 0 & 0.0 & 7,495 & 0.4 & 33,200 & 1.7 \\
\hline Tobacco ........... & 683 & 0.1 & 30,491 & 4.8 & 765 & 0.1 & 0 & 0.0 \\
\hline Sugar cane ........... & 0 & 0.0 & 0 & 0.0 & 0 & 0.0 & 0 & 0.0 \\
\hline Sunflowers . . . . . . . . . & 395 & 0.0 & 0 & 0.0 & 804 & 0.0 & 21,098 & 1.1 \\
\hline Vegetables ............. & 6,424 & 0.2 & 24,031 & 0.7 & 250,099 & 7.0 & 13,728 & 0.4 \\
\hline Field grass . . . . . . . . . . & 54,240 & 4.1 & 0 & 0.0 & 1,874 & 0.1 & 2,669 & 0.2 \\
\hline Sugar beets. . . . . . . . . & 3,245 & 0.3 & 0 & 0.0 & 0 & 0.0 & 193,007 & 15.7 \\
\hline All row crops . . . . . . . . & $1,739,765$ & 0.7 & $1,562,853$ & 0.6 & $1,511,813$ & 0.6 & $1,374,748$ & 0.5 \\
\hline
\end{tabular}


N Table 3. National harvested area of individual row crops in counties classified in each row crop category-Continued

\begin{tabular}{|c|c|c|c|c|c|c|c|c|}
\hline \multirow[t]{2}{*}{ Individual row crops } & \multicolumn{2}{|c|}{$\begin{array}{c}\text { Corn }>50 \text { percent, } \\
\text { sorghum }>10 \text { percent }\end{array}$} & \multicolumn{2}{|c|}{ Sorghum $>50$ percent } & \multicolumn{2}{|c|}{$\begin{array}{c}\text { Sorghum }>50 \text { percent, } \\
\text { cotton }>10 \text { percent }\end{array}$} & \multicolumn{2}{|c|}{$\begin{array}{c}\text { Corn }>20 \text { percent, } \\
\text { wheat and other } \\
\text { grains }>20 \text { percent, dried } \\
\text { beans and peas }>10 \text { per- } \\
\text { cent }\end{array}$} \\
\hline & $\begin{array}{l}\text { Category } \\
\text { total area }\end{array}$ & $\begin{array}{l}\text { Percentage of } \\
\text { national total }\end{array}$ & $\begin{array}{l}\text { Category } \\
\text { total area }\end{array}$ & $\begin{array}{c}\text { Percentage } \\
\text { of national } \\
\text { total }\end{array}$ & $\begin{array}{l}\text { Category } \\
\text { total area }\end{array}$ & $\begin{array}{c}\text { Percentage } \\
\text { of national } \\
\text { total }\end{array}$ & $\begin{array}{l}\text { Category } \\
\text { total area }\end{array}$ & $\begin{array}{c}\text { Percentage } \\
\text { of national } \\
\text { total }\end{array}$ \\
\hline$\overline{\text { Alfalfa } \ldots \ldots \ldots \ldots \ldots}$ & 27,527 & 0.1 & 56,709 & 0.2 & 4,582 & 0.0 & 83,045 & 0.4 \\
\hline Corn . & 757,652 & 1.2 & 138,430 & 0.2 & 152,093 & 0.2 & 431,074 & 0.7 \\
\hline Soybeans & 165,469 & 0.3 & 148,774 & 0.3 & 270 & 0.0 & 33,525 & 0.1 \\
\hline Wheat and other grains.... & 101,645 & 0.1 & 301,268 & 0.4 & 54,442 & 0.1 & 327,007 & 0.4 \\
\hline Cotton. . . . . . . . . & 5,119 & 0.1 & 1,836 & 0.0 & 323,632 & 3.4 & 0 & 0.0 \\
\hline Peanuts ............. & 1,389 & 0.1 & 98 & 0.0 & 0 & 0.0 & 0 & 0.0 \\
\hline Rice $\ldots \ldots \ldots \ldots \ldots$ & 25,380 & 1.1 & 4,353 & 0.2 & 0 & 0.0 & 0 & 0.0 \\
\hline Potatoes $\ldots \ldots \ldots \ldots \ldots$ & 3 & 0.0 & 0 & 0.0 & 0 & 0.0 & 6,706 & 0.5 \\
\hline Sorghum ........... & 256,135 & 2.5 & 602,417 & 5.9 & 594,855 & 5.8 & 6,783 & 0.1 \\
\hline Dried beans and peas ..... & 0 & 0.0 & 0 & 0.0 & 629 & 0.0 & 240,282 & 12.2 \\
\hline Tobacco ............ & 0 & 0.0 & 0 & 0.0 & 0 & 0.0 & 0 & 0.0 \\
\hline Sugar cane...$\ldots \ldots \ldots$ & 0 & 0.0 & 0 & 0.0 & 25,578 & 3.1 & 0 & 0.0 \\
\hline Sunflowers . . . . . . . . . & 1,011 & 0.1 & 1,917 & 0.1 & 0 & 0.0 & 486 & 0.0 \\
\hline Vegetables........... & 1,957 & 0.1 & 5,430 & 0.2 & 90,419 & 2.5 & 2,233 & 0.0 \\
\hline Field grass $\ldots \ldots \ldots \ldots$ & 0 & 0.0 & 3,649 & 0.3 & 0 & 0.0 & 0 & 0.0 \\
\hline Sugar beets . . . . . . . . & 0 & 0.0 & 0 & 0.0 & 0 & 0.0 & 86,661 & 7.1 \\
\hline All row crops $\ldots \ldots \ldots \ldots$ & $1,343,287$ & 0.5 & $1,264,881$ & 0.5 & $1,246,500$ & 0.5 & $1,217,802$ & 0.5 \\
\hline
\end{tabular}


Table 3. National harvested area of individual row crops in counties classified in each row crop category-Continued

\begin{tabular}{|c|c|c|c|c|c|c|c|c|}
\hline \multirow{3}{*}{ Individual row crops } & \multicolumn{8}{|c|}{ Row crop categories } \\
\hline & \multicolumn{2}{|c|}{ Rice $>\mathbf{5 0}$ percent } & \multicolumn{2}{|c|}{$\begin{array}{c}\text { Wheat and other } \\
\text { grains }>20 \text { percent, } \\
\text { soybeans }>20 \text { percent, } \\
\text { cotton }>10 \text { percent }\end{array}$} & \multicolumn{2}{|c|}{$\begin{array}{l}\text { Corn }>20 \text { percent, } \\
\text { soybeans }>20 \text { percent, } \\
\text { cotton }>10 \text { percent }\end{array}$} & \multicolumn{2}{|c|}{ Vegetables $>50$ percent } \\
\hline & $\begin{array}{l}\text { Category } \\
\text { total area }\end{array}$ & $\begin{array}{l}\text { Percentage of } \\
\text { national total }\end{array}$ & $\begin{array}{l}\text { Category } \\
\text { total area }\end{array}$ & $\begin{array}{c}\text { Percentage } \\
\text { of national } \\
\text { total }\end{array}$ & $\begin{array}{l}\text { Category } \\
\text { total area }\end{array}$ & $\begin{array}{c}\text { Percentage } \\
\text { of national } \\
\text { total }\end{array}$ & $\begin{array}{l}\text { Category } \\
\text { total area }\end{array}$ & $\begin{array}{c}\text { Percentage } \\
\text { of national } \\
\text { total }\end{array}$ \\
\hline Alfalfa .............. & 33,559 & 0.1 & 4,677 & 0.0 & 9,689 & 0.0 & 34,011 & 0.1 \\
\hline Corn $\ldots \ldots \ldots \ldots \ldots$ & 39,258 & 0.1 & 36,059 & 0.1 & 246,777 & 0.4 & 25,365 & 0.0 \\
\hline Soybeans $\ldots \ldots \ldots \ldots$ & 155,354 & 0.3 & 408,141 & 0.7 & 346,526 & 0.6 & 14,111 & 0.0 \\
\hline Wheat and other grains ... & 149,361 & 0.2 & 196,092 & 0.3 & 117,978 & 0.2 & 99,388 & 0.1 \\
\hline Cotton $\ldots \ldots \ldots \ldots \ldots$ & 5,350 & 0.1 & 242,807 & 2.6 & 231,794 & 2.4 & 683 & 0.0 \\
\hline Peanuts............. & 0 & 0.0 & 46,510 & 3.3 & 33,141 & 2.3 & 13 & 0.0 \\
\hline Rice $\ldots \ldots \ldots \ldots \ldots$ & 638,272 & 26.4 & 25,565 & 1.1 & 0 & 0.0 & 0 & 0.0 \\
\hline Potatoes . . . . . . . . . . & 220 & 0.0 & 0 & 0.0 & 1 & 0.0 & 17,093 & 1.4 \\
\hline Sorghum. . . . . . . . . & 22,026 & 0.2 & 50,321 & 0.5 & 11,241 & 0.1 & 1,300 & 0.0 \\
\hline Dried beans and peas..... & 43,437 & 2.2 & 0 & 0.0 & 0 & 0.0 & 13,185 & 0.7 \\
\hline Tobacco ............ & 0 & 0.0 & 693 & 0.1 & 9,334 & 1.5 & 149 & 0.0 \\
\hline Sugar cane...$\ldots \ldots \ldots$ & 6,498 & 0.8 & 0 & 0.0 & 0 & 0.0 & 0 & 0.0 \\
\hline Sunflowers . . . . . . . . . & 3,530 & 0.2 & 0 & 0.0 & 0 & 0.0 & 0 & 0.0 \\
\hline Vegetables .......... & 41,647 & 1.2 & 10,197 & 0.3 & 15,203 & 0.4 & 607,359 & 16.9 \\
\hline Field grass . . . . . . . . . & 5,859 & 0.4 & 1,550 & 0.1 & 349 & 0.0 & 4,499 & 0.3 \\
\hline Sugar beets. . . . . . . . & 28,710 & 2.3 & 0 & 0.0 & 0 & 0.0 & 4,598 & 0.4 \\
\hline All row crops . . . . . . . . & $1,173,081$ & 0.5 & $1,022,612$ & 0.4 & $1,022,033$ & 0.4 & 821,754 & 0.3 \\
\hline
\end{tabular}


E Table 3. National harvested area of individual row crops in counties classified in each row crop category-Continued

\begin{tabular}{|c|c|c|c|c|c|c|c|c|}
\hline \multirow{3}{*}{ Individual row crops } & \multicolumn{8}{|c|}{ Row crop categories } \\
\hline & \multicolumn{2}{|c|}{$\begin{array}{c}\text { Corn }>20 \text { percent, } \\
\text { alfalfa }>20 \text { percent, } \\
\text { soybeans }>20 \text { percent }\end{array}$} & \multicolumn{2}{|c|}{$\begin{array}{c}\text { Corn }>20 \text { percent, } \\
\text { soybeans }>20 \text { percent, } \\
\text { vegetables }>10 \text { percent }\end{array}$} & \multicolumn{2}{|c|}{$\begin{array}{c}\text { Wheat and other grains }> \\
20 \text { percent, alfalfa }>20 \\
\text { percent, } \\
\text { potatoes }>10 \text { percent }\end{array}$} & \multicolumn{2}{|c|}{$\begin{array}{c}\text { Cotton }>50 \text { percent, } \\
\text { vegetables }>20 \text { percent }\end{array}$} \\
\hline & $\begin{array}{l}\text { Category } \\
\text { total area }\end{array}$ & $\begin{array}{l}\text { Percentage of } \\
\text { national total }\end{array}$ & $\begin{array}{l}\text { Category } \\
\text { total area }\end{array}$ & $\begin{array}{c}\text { Percentage } \\
\text { of national } \\
\text { total }\end{array}$ & $\begin{array}{l}\text { Category } \\
\text { total area }\end{array}$ & $\begin{array}{c}\text { Percentage } \\
\text { of national } \\
\text { total }\end{array}$ & $\begin{array}{l}\text { Category } \\
\text { total area }\end{array}$ & $\begin{array}{c}\text { Percentage } \\
\text { of national } \\
\text { total }\end{array}$ \\
\hline$\ldots \ldots \ldots \ldots$ & 189,124 & 0.8 & 30,124 & 0.1 & 215,196 & 0.9 & 90,548 & 0.4 \\
\hline Corn $\ldots \ldots \ldots \ldots \ldots$ & 316,840 & 0.5 & 217,309 & 0.3 & 39,348 & 0.1 & 27,287 & 0.0 \\
\hline Soybeans $\ldots \ldots \ldots \ldots$ & 229,501 & 0.4 & 278,677 & 0.5 & 1,896 & 0.0 & 0 & 0.0 \\
\hline Wheat and other grains.... & 61,152 & 0.1 & 99,950 & 0.1 & 332,957 & 0.5 & 81,740 & 0.1 \\
\hline Cotton. & 0 & 0.0 & 9,381 & 0.1 & 0 & 0.0 & 352,951 & 3.7 \\
\hline Peanuts . & 0 & 0.0 & 5,052 & 0.4 & 0 & 0.0 & 0 & 0.0 \\
\hline Rice & 0 & 0.0 & 0 & 0.0 & 0 & 0.0 & 9,171 & 0.4 \\
\hline Potatoes $\ldots \ldots \ldots \ldots$ & 10 & 0.0 & 9,704 & 0.8 & 138,086 & 11.2 & 0 & 0.0 \\
\hline Sorghum . . . . . . . . & 773 & 0.0 & 2,461 & 0.0 & 0 & 0.0 & 3,937 & 0.0 \\
\hline Dried beans and peas ..... & 0 & 0.0 & 0 & 0.0 & 14,924 & 0.8 & 8,824 & 0.4 \\
\hline Tobacco ............. & 4,690 & 0.7 & 20,481 & 3.3 & 0 & 0.0 & 0 & 0.0 \\
\hline Sugar cane...$\ldots \ldots \ldots$ & 0 & 0.0 & 0 & 0.0 & 0 & 0.0 & 0 & 0.0 \\
\hline Sunflowers . . . . . . . . & 0 & 0.0 & 0 & 0.0 & 0 & 0.0 & 0 & 0.0 \\
\hline Vegetables............ & 4,941 & 0.1 & 130,220 & 3.6 & 32,282 & 0.9 & 154,917 & 4.3 \\
\hline Field grass $\ldots \ldots \ldots \ldots$ & 39 & 0.0 & 67 & 0.0 & 5,298 & 0.4 & 34,859 & 2.6 \\
\hline Sugar beets $\ldots \ldots \ldots \ldots$ & 0 & 0.0 & 0 & 0.0 & 12,390 & 1.0 & 23,302 & 1.9 \\
\hline All row crops $\ldots \ldots \ldots$ & 807,070 & 0.3 & 803,426 & 0.3 & 792,377 & 0.3 & 787,536 & 0.3 \\
\hline
\end{tabular}


Table 3. National harvested area of individual row crops in counties classified in each row crop category-Continued

\begin{tabular}{|c|c|c|c|c|c|c|c|c|}
\hline \multirow{3}{*}{ Individual row crops } & \multicolumn{8}{|c|}{ Row crop categories } \\
\hline & \multicolumn{2}{|c|}{$\begin{array}{c}\text { Corn }>20 \text { percent, } \\
\text { soybeans }>20 \text { percent, } \\
\text { tobacco }>10 \text { percent }\end{array}$} & \multicolumn{2}{|c|}{ Peanuts $>50$ percent } & \multicolumn{2}{|c|}{$\begin{array}{c}\text { Wheat and other } \\
\text { grains }>20 \text { percent, } \\
\text { alfalfa }>20 \text { percent, } \\
\text { sorghum }>10 \text { percent }\end{array}$} & \multicolumn{2}{|c|}{$\begin{array}{c}\text { Corn }>20 \text { percent, } \\
\text { alfalfa }>20 \text { percent, } \\
\text { tobacco }>10 \text { percent }\end{array}$} \\
\hline & $\begin{array}{l}\text { Category } \\
\text { total area }\end{array}$ & $\begin{array}{l}\text { Percentage of } \\
\text { national total }\end{array}$ & $\begin{array}{l}\text { Category } \\
\text { total area }\end{array}$ & $\begin{array}{c}\text { Percentage } \\
\text { of national } \\
\text { total }\end{array}$ & $\begin{array}{l}\text { Category } \\
\text { total area }\end{array}$ & $\begin{array}{c}\text { Percentage } \\
\text { of national } \\
\text { total }\end{array}$ & $\begin{array}{c}\text { Category } \\
\text { total area }\end{array}$ & $\begin{array}{c}\text { Percentage } \\
\text { of national } \\
\text { total }\end{array}$ \\
\hline$\overline{\text { Alfalfa . }}$ & 6,485 & 0.0 & 9,541 & 0.0 & 198,564 & 0.8 & 196,173 & 0.8 \\
\hline Corn . . . . . . . . . & 249,193 & 0.4 & 101,361 & 0.2 & 63,185 & 0.1 & 257,323 & 0.4 \\
\hline Soybeans ............ & 272,239 & 0.5 & 58,035 & 0.1 & 7,962 & 0.0 & 27,549 & 0.0 \\
\hline Wheat and other grains ... & 75,624 & 0.1 & 90,494 & 0.1 & 303,314 & 0.4 & 66,255 & 0.1 \\
\hline Cotton $\ldots \ldots \ldots \ldots$ & 5,602 & 0.1 & 26,643 & 0.3 & 732 & 0.0 & 0 & 0.0 \\
\hline Peanuts. . . . . . . . . . & 6,734 & 0.5 & 375,068 & 26.4 & 0 & 0.0 & 0 & 0.0 \\
\hline Rice $\ldots \ldots \ldots \ldots \ldots$ & 0 & 0.0 & 0 & 0.0 & 0 & 0.0 & 0 & 0.0 \\
\hline Potatoes . . . . . . . . . & 470 & 0.0 & 0 & 0.0 & 0 & 0.0 & 495 & 0.0 \\
\hline Sorghum. . & 1,196 & 0.0 & 16,723 & 0.2 & 95,985 & 0.9 & 316 & 0.0 \\
\hline Dried beans and peas..... & 0 & 0.0 & 0 & 0.0 & 143 & 0.0 & 0 & 0.0 \\
\hline Tobacco ........... & 92,211 & 14.6 & 1,837 & 0.3 & 0 & 0.0 & 128,204 & 20.4 \\
\hline Sugar cane ..... & 0 & 0.0 & 0 & 0.0 & 0 & 0.0 & 0 & 0.0 \\
\hline Sunflowers . . . . . . . . & 0 & 0.0 & 0 & 0.0 & 5,170 & 0.3 & 0 & 0.0 \\
\hline Vegetables ........... & 25,687 & 0.7 & 13,734 & 0.4 & 682 & 0.0 & 3,184 & 0.0 \\
\hline Field grass . . . . . . . . & 0 & 0.0 & 327 & 0.0 & 13,361 & 1.0 & 1,292 & 0.0 \\
\hline Sugar beets. . . . . . . . & 0 & 0.0 & 0 & 0.0 & 0 & 0.0 & 0 & 0.0 \\
\hline All row crops $\ldots \ldots \ldots \ldots$ & 735,441 & 0.3 & 693,763 & 0.3 & 689,098 & 0.3 & 680,791 & 0.3 \\
\hline
\end{tabular}


Table 3. National harvested area of individual row crops in counties classified in each row crop category-Continued

\begin{tabular}{|c|c|c|c|c|c|c|c|c|}
\hline \multirow{3}{*}{ Individual row crops } & \multicolumn{8}{|c|}{ Row crop categories } \\
\hline & \multicolumn{2}{|c|}{$\begin{array}{c}\text { Corn }>20 \text { percent, } \\
\text { wheat and other } \\
\text { grains }>20 \text { percent, } \\
\text { cotton }>10 \text { percent }\end{array}$} & \multicolumn{2}{|c|}{$\begin{array}{l}\text { Wheat and other } \\
\text { grains }>20 \text { percent, } \\
\text { alfalfa }>20 \text { percent, } \\
\text { cotton }>10 \text { percent }\end{array}$} & \multicolumn{2}{|c|}{$\begin{array}{c}\text { Corn }>20 \text { percent, } \\
\text { soybeans }>20 \text { percent, } \\
\text { dried beans and } \\
\text { peas }>10 \text { percent }\end{array}$} & \multicolumn{2}{|c|}{$\begin{array}{c}\text { Wheat and other } \\
\text { grains }>20 \text { percent, } \\
\text { alfalfa }>20 \text { percent, } \\
\text { vegetables }>10 \text { percent }\end{array}$} \\
\hline & $\begin{array}{l}\text { Category } \\
\text { total area }\end{array}$ & $\begin{array}{l}\text { Percentage of } \\
\text { national total }\end{array}$ & $\begin{array}{l}\text { Category } \\
\text { total area }\end{array}$ & $\begin{array}{c}\text { Percentage } \\
\text { of national } \\
\text { total }\end{array}$ & $\begin{array}{l}\text { Category } \\
\text { total area }\end{array}$ & $\begin{array}{c}\text { Percentage } \\
\text { of national } \\
\text { total }\end{array}$ & $\begin{array}{l}\text { Category } \\
\text { total area }\end{array}$ & $\begin{array}{c}\text { Percentage } \\
\text { of national } \\
\text { total }\end{array}$ \\
\hline$\overline{\text { Alfalfa. . . . . . . . . . . }}$ & 5,770 & 0.0 & 142,612 & 0.6 & 24,501 & 0.1 & 169,992 & 0.7 \\
\hline Corn $\ldots \ldots \ldots \ldots \ldots$ & 184,112 & 0.3 & 96,243 & 0.1 & 191,247 & 0.3 & 32,189 & 0.0 \\
\hline Soybeans $\ldots \ldots \ldots \ldots$ & 10,952 & 0.0 & 0 & 0.0 & 201,374 & 0.4 & 3,570 & 0.0 \\
\hline Wheat and other grains.... & 226,503 & 0.3 & 128,236 & 0.2 & 44,479 & 0.1 & 167,885 & 0.2 \\
\hline Cotton. . . . . . . . . & 132,091 & 1.4 & 196,676 & 2.1 & 0 & 0.0 & 54,724 & 0.6 \\
\hline Peanuts . . . . . . . . . . . & 0 & 0.0 & 0 & 0.0 & 0 & 0.0 & 0 & 0.0 \\
\hline Rice ....... & 0 & 0.0 & 6,353 & 0.3 & 0 & 0.0 & 0 & 0.0 \\
\hline Potatoes $\ldots \ldots \ldots \ldots$ & 2,360 & 0.2 & 500 & 0.0 & 6,880 & 0.6 & 16,244 & 1.3 \\
\hline Sorghum $\ldots \ldots \ldots \ldots$ & 88,981 & 0.9 & 4,055 & 0.0 & 885 & 0.0 & 1,256 & 0.0 \\
\hline Dried beans and peas ..... & 0 & 0.0 & 18,414 & 0.9 & 110,768 & 5.6 & 3,444 & 0.2 \\
\hline Tobacco $\ldots \ldots \ldots \ldots$ & 0 & 0.0 & 0 & 0.0 & 0 & 0.0 & 0 & 0.0 \\
\hline Sugar cane...$\ldots \ldots \ldots$ & 0 & 0.0 & 0 & 0.0 & 0 & 0.0 & 0 & 0.0 \\
\hline Sunflowers $\ldots \ldots \ldots \ldots$ & 1,307 & 0.1 & 0 & 0.0 & 0 & 0.0 & 0 & 0.0 \\
\hline Vegetables. ............ & 14,312 & 0.4 & 34,865 & 1.0 & 12,275 & 0.3 & 137,572 & 3.8 \\
\hline Field grass $\ldots \ldots \ldots \ldots$ & 0 & 0.0 & 0 & 0.0 & 0 & 0.0 & 21,560 & 1.6 \\
\hline Sugar beets . . . . . . . . & 11,225 & 0.9 & 19,664 & 1.6 & 53,538 & 4.4 & 115 & 0.0 \\
\hline All row crops $\ldots \ldots \ldots \ldots$ & 677,613 & 0.3 & 647,618 & 0.3 & 645,947 & 0.3 & 608,551 & 0.2 \\
\hline
\end{tabular}


Table 3. National harvested area of individual row crops in counties classified in each row crop category-Continued

\begin{tabular}{|c|c|c|c|c|c|c|c|c|}
\hline \multirow{3}{*}{ Individual row crops } & \multicolumn{8}{|c|}{ Row crop categories } \\
\hline & \multicolumn{2}{|c|}{$\begin{array}{c}\text { Wheat and other } \\
\text { grains }>20 \text { percent, } \\
\text { soybeans }>20 \text { percent, } \\
\text { peanuts }>10 \text { percent } \\
\end{array}$} & \multicolumn{2}{|c|}{$\begin{array}{c}\text { Alfalfa }>50 \text { percent, } \\
\text { vegetables }>10 \text { percent }\end{array}$} & \multicolumn{2}{|c|}{$\begin{array}{c}\text { Wheat and other } \\
\text { grains }>20 \text { percent, } \\
\text { alfalfa }>20 \text { percent, } \\
\text { sugarbeets }>10 \text { percent }\end{array}$} & \multicolumn{2}{|c|}{$\begin{array}{c}\text { Wheat and other } \\
\text { grains }>50 \text { percent, } \\
\text { field grass }>10 \text { percent }\end{array}$} \\
\hline & $\begin{array}{l}\text { Category } \\
\text { total area }\end{array}$ & $\begin{array}{l}\text { Percentage of } \\
\text { national total }\end{array}$ & $\begin{array}{l}\text { Category } \\
\text { total area }\end{array}$ & $\begin{array}{c}\text { Percentage } \\
\text { of national } \\
\text { total }\end{array}$ & $\begin{array}{l}\text { Category } \\
\text { total area }\end{array}$ & $\begin{array}{c}\text { Percentage } \\
\text { of national } \\
\text { tota }\end{array}$ & $\begin{array}{l}\text { Category } \\
\text { total area }\end{array}$ & $\begin{array}{c}\text { Percentage } \\
\text { of national } \\
\text { total }\end{array}$ \\
\hline$\overline{\text { Alfalfa } \ldots \ldots \ldots \ldots \ldots}$ & 2,151 & 0.0 & 249,847 & 1.1 & 154,265 & 0.7 & 50,860 & 0.2 \\
\hline Corn . . . . . . . . . & 76,468 & 0.1 & 4,568 & 0.0 & 48,285 & 0.1 & 8,710 & 0.0 \\
\hline Soybeans . . . . . . . . . . . & 146,611 & 0.3 & 0 & 0.0 & 0 & 0.0 & 3,005 & 0.0 \\
\hline Wheat and other grains ... & 130,727 & 0.2 & 83,601 & 0.1 & 157,807 & 0.2 & 317,787 & 0.4 \\
\hline Cotton & 25,833 & 0.3 & 38,994 & 0.4 & 0 & 0.0 & 0 & 0.0 \\
\hline Peanuts. . . . . . . . . . & 145,540 & 10.2 & 0 & 0.0 & 0 & 0.0 & 0 & 0.0 \\
\hline Rice $\ldots \ldots \ldots \ldots \ldots$ & 0 & 0.0 & 0 & 0.0 & 0 & 0.0 & 0 & 0.0 \\
\hline Potatoes ............ & 0 & 0.0 & 22 & 0.0 & 8,505 & 0.7 & 673 & 0.1 \\
\hline Sorghum. . . . . . . . . . & 12,402 & 0.1 & 1,072 & 0.0 & 0 & 0.0 & 42 & 0.0 \\
\hline Dried beans and peas..... & 0 & 0.0 & 275 & 0.0 & 23,530 & 1.2 & 10,060 & 0.5 \\
\hline Tobacco ........... & 369 & 0.1 & 0 & 0.0 & 0 & 0.0 & 0 & 0.0 \\
\hline Sugar cane ........... & 0 & 0.0 & 0 & 0.0 & 0 & 0.0 & 0 & 0.0 \\
\hline Sunflowers . . . . . . . . . & 0 & 0.0 & 0 & 0.0 & 0 & 0.0 & 7,380 & 0.4 \\
\hline Vegetables ........... & 12,648 & 0.4 & 110,413 & 3.1 & 12,616 & 0.4 & 18,516 & 0.5 \\
\hline Field grass . . . . . . . . . . & 30 & 0.0 & 21,451 & 1.6 & 25,417 & 1.9 & 87,001 & 6.6 \\
\hline Sugar beets. . . . . . . . & 0 & 0.0 & 39,770 & 3.2 & 88,548 & 7.2 & 120 & 0.0 \\
\hline All row crops $\ldots \ldots \ldots \ldots$ & 552,779 & 0.2 & 550,013 & 0.2 & 518,973 & 0.2 & 504,154 & 0.2 \\
\hline
\end{tabular}


D Table 3. National harvested area of individual row crops in counties classified in each row crop category-Continued

\begin{tabular}{|c|c|c|c|c|c|c|c|c|}
\hline \multirow{3}{*}{ Individual row crops } & \multicolumn{8}{|c|}{ Row crop categories } \\
\hline & \multicolumn{2}{|c|}{$\begin{array}{l}\text { Sugar cane }>50 \text { percent. } \\
\text { vegetables }>10 \text { percent }\end{array}$} & \multicolumn{2}{|c|}{$\begin{array}{c}\text { Wheat and other } \\
\text { grains }>50 \text { percent, } \\
\text { vegetables }>10 \text { percent }\end{array}$} & \multicolumn{2}{|c|}{$\begin{array}{l}\text { Field and grass } \\
\text { seed }>50 \text { percent }\end{array}$} & \multicolumn{2}{|c|}{ Sugar cane $>50$ percent } \\
\hline & $\begin{array}{l}\text { Category } \\
\text { total area }\end{array}$ & $\begin{array}{l}\text { Percentage of } \\
\text { national total }\end{array}$ & $\begin{array}{l}\text { Category } \\
\text { total area }\end{array}$ & $\begin{array}{c}\text { Percentage } \\
\text { of national } \\
\text { total }\end{array}$ & $\begin{array}{l}\text { Category } \\
\text { total area }\end{array}$ & $\begin{array}{c}\text { Percentage } \\
\text { of national } \\
\text { total }\end{array}$ & $\begin{array}{l}\text { Category } \\
\text { total area }\end{array}$ & $\begin{array}{c}\begin{array}{c}\text { Percentage } \\
\text { of national } \\
\text { total }\end{array} \\
\end{array}$ \\
\hline Alfalfa............... & 0 & 0.0 & 43,487 & 0.2 & 43,589 & 0.2 & 660 & 0.0 \\
\hline Corn $\ldots \ldots \ldots \ldots \ldots$ & 0 & 0.0 & 22,865 & 0.0 & 9,669 & 0.0 & 7,746 & 0.0 \\
\hline Soybeans $\ldots \ldots \ldots \ldots$ & 0 & 0.0 & 963 & 0.0 & 5,139 & 0.0 & 35,975 & 0.1 \\
\hline Wheat and other grains.... & 0 & 0.0 & 214,334 & 0.3 & 71,214 & 0.1 & 3,578 & 0.0 \\
\hline Cotton............ & 0 & 0.0 & 305 & 0.0 & 0 & 0.0 & 0 & 0.0 \\
\hline Peanuts ............. & 0 & 0.0 & 0 & 0.0 & 0 & 0.0 & 0 & 0.0 \\
\hline Rice $\ldots \ldots \ldots \ldots \ldots$ & 4,826 & 0.2 & 23,207 & 1.0 & 0 & 0.0 & 5,731 & 0.2 \\
\hline Potatoes . . . . . . . . . . & 0 & 0.0 & 0 & 0.0 & 0 & 0.0 & 0 & 0.0 \\
\hline Sorghum . . . . . . . . & 0 & 0.0 & 986 & 0.0 & 5,624 & 0.1 & 0 & 0.0 \\
\hline Dried beans and peas ..... & 0 & 0.0 & 4,505 & 0.2 & 0 & 0.0 & 0 & 0.0 \\
\hline Tobacco $\ldots \ldots \ldots \ldots$ & 0 & 0.0 & 0 & 0.0 & 0 & 0.0 & 0 & 0.0 \\
\hline Sugar cane $\ldots \ldots \ldots \ldots$ & 400,472 & 48.2 & 0 & 0.0 & 0 & 0.0 & 378,883 & 45.6 \\
\hline Sunflowers $\ldots \ldots \ldots \ldots$ & 0 & 0.0 & 7,925 & 0.4 & 0 & 0.0 & 0 & 0.0 \\
\hline Vegetables........... & 100,744 & 2.8 & 100,686 & 2.8 & 13,691 & 0.4 & 2,515 & 0.0 \\
\hline Field grass $\ldots \ldots \ldots \ldots$ & 0 & 0.0 & 953 & 0.1 & 292,386 & 22.0 & 0 & 0.0 \\
\hline Sugar beets . . . . . . . . & 0 & 0.0 & 22,752 & 1.9 & 728 & 0.1 & 0 & 0.0 \\
\hline All row crops $\ldots \ldots \ldots$ & 506,042 & 0.2 & 442,968 & 0.2 & 442,040 & 0.2 & 435,088 & 0.2 \\
\hline
\end{tabular}


Table 3. National harvested area of individual row crops in counties classified in each row crop category-Continued

\begin{tabular}{|c|c|c|c|c|c|c|c|c|}
\hline \multirow{3}{*}{ Individual row crops } & \multicolumn{8}{|c|}{ Row crop categories } \\
\hline & \multicolumn{2}{|c|}{$\begin{array}{c}\text { Corn }>20 \text { percent, } \\
\text { alfalfa }>20 \text { percent, } \\
\text { dried beans and } \\
\text { peas }>10 \text { percent }\end{array}$} & \multicolumn{2}{|c|}{$\begin{array}{c}\text { Corn }>20 \text { percent, } \\
\text { wheat and other } \\
\text { grains }>20 \text { percent, } \\
\text { peanuts }>10 \text { percent }\end{array}$} & \multicolumn{2}{|c|}{$\begin{array}{c}\text { Corn }>20 \text { percent, } \\
\text { wheat and other } \\
\text { grains }>20 \text { percent, } \\
\text { vegetables }>10 \text { percent }\end{array}$} & \multicolumn{2}{|c|}{$\begin{array}{c}\text { Sorghum }>50 \text { percent, } \\
\text { rice }>10 \text { percent }\end{array}$} \\
\hline & $\begin{array}{l}\text { Category } \\
\text { total area }\end{array}$ & $\begin{array}{l}\text { Percentage of } \\
\text { national total }\end{array}$ & $\begin{array}{l}\text { Category } \\
\text { total area }\end{array}$ & $\begin{array}{c}\text { Percentage } \\
\text { of national } \\
\text { total }\end{array}$ & $\begin{array}{l}\text { Category } \\
\text { total area }\end{array}$ & $\begin{array}{c}\text { Percentage } \\
\text { of national } \\
\text { total }\end{array}$ & $\begin{array}{l}\text { Category } \\
\text { total area }\end{array}$ & $\begin{array}{c}\text { Percentage } \\
\text { of national } \\
\text { total }\end{array}$ \\
\hline Alfalfa .............. & 82,372 & 0.3 & 2,391 & 0.0 & 55,122 & 0.2 & 931 & 0.0 \\
\hline Corn $\ldots \ldots \ldots \ldots \ldots$ & 139,868 & 0.2 & 72,865 & 0.1 & 103,922 & 0.2 & 72,256 & 0.1 \\
\hline Soybeans $\ldots \ldots \ldots \ldots$ & 11,487 & 0.0 & 33,036 & 0.1 & 6,708 & 0.0 & 15,754 & 0.0 \\
\hline Wheat and other grains ... & 53,042 & 0.1 & 82,912 & 0.1 & 75,236 & 0.1 & 922 & 0.0 \\
\hline Cotton ............ & 0 & 0.0 & 17,967 & 0.2 & 0 & 0.0 & 24,301 & 0.3 \\
\hline Peanuts............. & 0 & 0.0 & 148,479 & 10.4 & 0 & 0.0 & 0 & 0.0 \\
\hline Rice $\ldots \ldots \ldots \ldots \ldots$ & 0 & 0.0 & 0 & 0.0 & 2,485 & 0.1 & 96,003 & 4.0 \\
\hline Potatoes . . . . . . . . . . & 11,343 & 0.9 & 1,382 & 0.1 & 1,892 & 0.2 & 0 & 0.0 \\
\hline Sorghum. . . . . . . . . & 2,773 & 0.0 & 21,866 & 0.2 & 95 & 0.0 & 126,982 & 1.2 \\
\hline Dried beans and peas..... & 74,701 & 3.8 & 2,356 & 0.1 & 30,715 & 1.6 & 0 & 0.0 \\
\hline Tobacco ............ & 0 & 0.0 & 1,607 & 0.3 & 61 & 0.0 & 0 & 0.0 \\
\hline Sugar cane...$\ldots \ldots \ldots$ & 0 & 0.0 & 0 & 0.0 & 0 & 0.0 & 0 & 0.0 \\
\hline Sunflowers . . . . . . . . . & 0 & 0.0 & 0 & 0.0 & 0 & 0.0 & 0 & 0.0 \\
\hline Vegetables .......... & 9,966 & 0.3 & 17,606 & 0.5 & 76,355 & 2.1 & 275 & 0.0 \\
\hline Field grass . . . . . . . . . & 849 & 0.1 & 2,784 & 0.2 & 1,276 & 0.0 & 0 & 0.0 \\
\hline Sugar beets. . . . . . . . & 34,174 & 2.8 & 0 & 0.0 & 4,634 & 0.4 & 0 & 0.0 \\
\hline All row crops $\ldots \ldots \ldots \ldots$ & 420,575 & 0.2 & 405,251 & 0.2 & 358,501 & 0.1 & 337,424 & 0.1 \\
\hline
\end{tabular}


जI Table 3. National harvested area of individual row crops in counties classified in each row crop category-Continued

\begin{tabular}{|c|c|c|c|c|c|c|c|c|}
\hline \multirow{3}{*}{ Individual row crops } & \multicolumn{8}{|c|}{ Row crop categories } \\
\hline & \multicolumn{2}{|c|}{$\begin{array}{l}\text { Field grass }>50 \text { percent, } \\
\text { vegetables }>10 \text { percent }\end{array}$} & \multicolumn{2}{|c|}{$\begin{array}{l}\text { Wheat and other } \\
\text { grains }>20 \text { percent, } \\
\text { alfalfa }>20 \text { percent, } \\
\text { dried beans and } \\
\text { peas }>10 \text { percent }\end{array}$} & \multicolumn{2}{|c|}{$\begin{array}{c}\text { Wheat and other } \\
\text { grains }>20 \text { percent, } \\
\text { soybeans }>20 \text { percent, } \\
\text { tobacco }>10 \text { percent }\end{array}$} & \multicolumn{2}{|c|}{$\begin{array}{c}\text { Corn }>20 \text { percent, } \\
\text { wheat and other } \\
\text { grains }>20 \text { percent, } \\
\text { tobacco }>10 \text { percent }\end{array}$} \\
\hline & $\begin{array}{l}\text { Category } \\
\text { total area }\end{array}$ & $\begin{array}{l}\text { Percentage of } \\
\text { national total }\end{array}$ & $\begin{array}{l}\text { Category } \\
\text { total area }\end{array}$ & $\begin{array}{c}\text { Percentage } \\
\text { of national } \\
\text { total }\end{array}$ & $\begin{array}{l}\text { Category } \\
\text { total area }\end{array}$ & $\begin{array}{c}\text { Percentage } \\
\text { of national } \\
\text { total }\end{array}$ & $\begin{array}{l}\text { Category } \\
\text { total area }\end{array}$ & $\begin{array}{c}\text { Percentage } \\
\text { of national } \\
\text { total }\end{array}$ \\
\hline$\overline{\text { Alfalfa. ................ }}$ & 7,274 & 0.0 & 79,749 & 0.3 & 9,230 & 0.0 & 13,140 & 0.1 \\
\hline Corn $\ldots \ldots \ldots \ldots \ldots$ & 5,329 & 0.0 & 11,896 & 0.0 & 33,672 & 0.1 & 50,050 & 0.1 \\
\hline Soybeans ........... & 0 & 0.0 & 0 & 0.0 & 75,835 & 0.1 & 21,001 & 0.0 \\
\hline Wheat and other grains.... & 52,899 & 0.1 & 69,447 & 0.1 & 59,912 & 0.1 & 49,701 & 0.1 \\
\hline Cotton............ & 0 & 0.0 & 0 & 0.0 & 0 & 0.0 & 0 & 0.0 \\
\hline Peanuts ............ & 2,500 & 0.2 & 0 & 0.0 & 83 & 0.0 & 72 & 0.0 \\
\hline Rice $\ldots \ldots \ldots \ldots \ldots$ & 0 & 0.0 & 0 & 0.0 & 0 & 0.0 & 0 & 0.0 \\
\hline Potatoes $\ldots \ldots \ldots \ldots$ & 1,068 & 0.1 & 16,395 & 1.3 & 93 & 0.0 & 133 & 0.0 \\
\hline Sorghum..... & 356 & 0.0 & 0 & 0.0 & 4,293 & 0.0 & 2,294 & 0.0 \\
\hline Dried beans and peas ..... & 200 & 0.0 & 56,192 & 2.8 & 0 & 0.0 & 0 & 0.0 \\
\hline Tobacco ..... & 0 & 0.0 & 0 & 0.0 & 47,895 & 7.6 & 39,559 & 6.3 \\
\hline Sugar cane .......... & 0 & 0.0 & 0 & 0.0 & 0 & 0.0 & 0 & 0.0 \\
\hline Sunflowers . . . . . . . & 0 & 0.0 & 0 & 0.0 & 0 & 0.0 & 0 & 0.0 \\
\hline Vegetables. ........... & 64,027 & 1.8 & 1,352 & 0.0 & 2,001 & 0.1 & 2,216 & 0.0 \\
\hline Field grass $\ldots \ldots \ldots \ldots$ & 122,941 & 9.3 & 1,319 & 0.1 & 56 & 0.0 & 49 & 0.0 \\
\hline Sugar beets . . . . . . . . . & 3,505 & 0.3 & 8,692 & 0.7 & 0 & 0.0 & 0 & 0.0 \\
\hline All row crops .. & 260,099 & 0.1 & 245,042 & 0.1 & 233,070 & 0.1 & 178,215 & 0.1 \\
\hline
\end{tabular}


Table 3. National harvested area of individual row crops in counties classified in each row crop category-Continued

\begin{tabular}{|c|c|c|c|c|c|c|c|c|}
\hline \multirow{3}{*}{$\begin{array}{l}\text { Individual row } \\
\text { crops }\end{array}$} & \multicolumn{8}{|c|}{ Row crop categories } \\
\hline & \multicolumn{2}{|c|}{$\begin{array}{c}\text { Potatoes }>50 \text { per- } \\
\text { cent }\end{array}$} & \multicolumn{2}{|c|}{$\begin{array}{c}\text { Corn }>50 \text { percent, } \\
\text { vegetables }>10 \text { per- } \\
\text { cent }\end{array}$} & \multicolumn{2}{|c|}{$\begin{array}{l}\text { Corn }>50 \text { percent, } \\
\text { tobacco }>10 \text { percent }\end{array}$} & \multicolumn{2}{|c|}{ Tobacco $>50$ percent } \\
\hline & $\begin{array}{l}\text { Category } \\
\text { total area }\end{array}$ & $\begin{array}{l}\text { Percent- } \\
\text { age of } \\
\text { national } \\
\text { total }\end{array}$ & $\begin{array}{l}\text { Category } \\
\text { total area }\end{array}$ & $\begin{array}{l}\text { Percent- } \\
\text { age of } \\
\text { national } \\
\text { total }\end{array}$ & $\begin{array}{l}\text { Category } \\
\text { total area }\end{array}$ & $\begin{array}{l}\text { Percent- } \\
\text { age of } \\
\text { national } \\
\text { total }\end{array}$ & $\begin{array}{l}\text { Category } \\
\text { total area }\end{array}$ & $\begin{array}{c}\text { Percent- } \\
\text { age of } \\
\text { national } \\
\text { total }\end{array}$ \\
\hline$\overline{\text { Alfalfa } \ldots \ldots \ldots \ldots}$ & 2,147 & 0.0 & 12,492 & 0.1 & 12,909 & 0.1 & 1,778 & 0.0 \\
\hline $\begin{array}{l}\text { Wheat and other } \\
\text { grains. }\end{array}$ & 38,652 & 0.1 & 7,672 & 0.0 & 7,548 & 0.0 & 674 & 0.0 \\
\hline Cotton .......... & 0 & 0.0 & 270 & 0.0 & 0 & 0.0 & 0 & 0.0 \\
\hline Peanuts........... & 0 & 0.0 & 417 & 0.0 & 0 & 0.0 & 0 & 0.0 \\
\hline Sorghum. . . . . . . . . & 0 & 0.0 & 0 & 0.0 & 64 & 0.0 & 10 & 0.0 \\
\hline Dried beans and peas. & 0 & 0.0 & 0 & 0.0 & 0 & 0.0 & 0 & 0.0 \\
\hline Tobacco .......... & 0 & 0.0 & 568 & 0.1 & 14,408 & 2.3 & 5,745 & 0.9 \\
\hline Sugar cane ........ & 0 & 0.0 & 0 & 0.0 & 0 & 0.0 & 0 & 0.0 \\
\hline Sunflowers . . . . . . & 0 & 0.0 & 0 & 0.0 & 0 & 0.0 & 0 & 0.0 \\
\hline Vegetables ........ & 16,168 & 0.5 & 26,060 & 0.7 & 1,341 & 0.0 & 195 & 0.0 \\
\hline Field grass . . . . . . & 0 & 0.0 & 547 & 0.0 & 228 & 0.0 & 0 & 0.0 \\
\hline Sugar beets. . . . . . . & 0 & 0.0 & 0 & 0.0 & 0 & 0.0 & 0 & 0.0 \\
\hline
\end{tabular}


N Table 4. National characterization of irrigation and fertilizer use and number of cattle, hogs, poultry, and turkeys within each row crop category

[All areas are in acres. >, greater than]

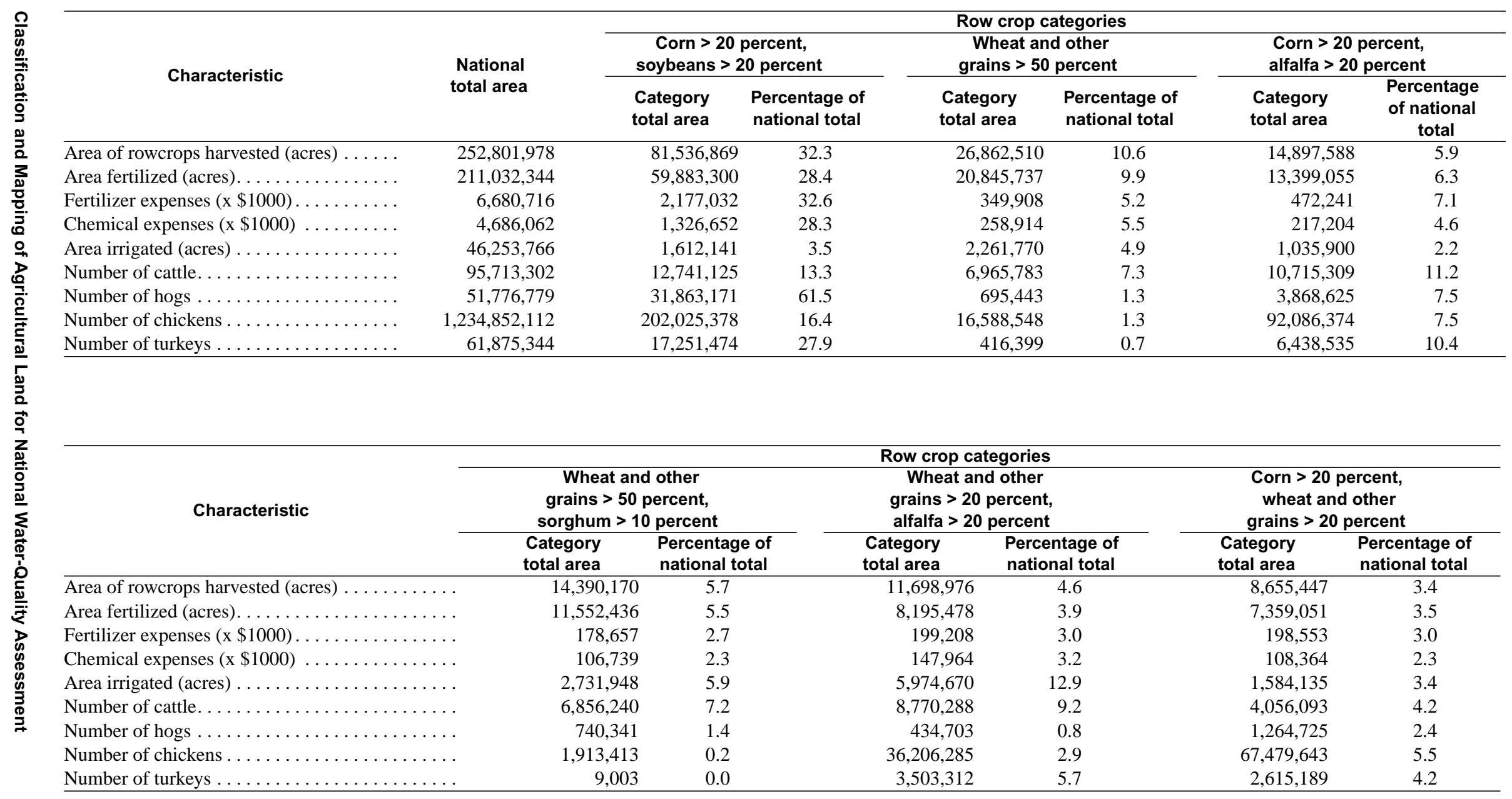


Table 4. National characterization of irrigation and fertilizer use and number of cattle, hogs, poultry, and turkeys within each row crop category—Continued

\begin{tabular}{|c|c|c|c|c|c|c|c|c|}
\hline \multirow{3}{*}{ Characteristic } & \multicolumn{8}{|c|}{ Row crop categories } \\
\hline & \multicolumn{2}{|c|}{$\begin{array}{c}\text { Wheat and other } \\
\text { grains }>50 \text { percent, } \\
\text { sunflowers }>10 \text { percent }\end{array}$} & \multicolumn{2}{|c|}{ Cotton $>\mathbf{5 0}$ percent } & \multicolumn{2}{|c|}{ Corn $>50$ percent } & \multicolumn{2}{|c|}{$\begin{array}{c}\text { Corn }>20 \text { percent, } \\
\text { soybeans }>20 \text { percent, } \\
\text { wheat and other } \\
\text { grains }>20 \text { percent }\end{array}$} \\
\hline & $\begin{array}{l}\text { Category } \\
\text { total area }\end{array}$ & $\begin{array}{c}\text { Percent- } \\
\text { age of } \\
\text { national } \\
\text { total }\end{array}$ & $\begin{array}{l}\text { Category } \\
\text { total area }\end{array}$ & $\begin{array}{l}\text { Percent- } \\
\text { age of } \\
\text { national } \\
\text { total }\end{array}$ & $\begin{array}{l}\text { Category } \\
\text { total area }\end{array}$ & $\begin{array}{c}\text { Percent- } \\
\text { age of } \\
\text { national } \\
\text { total }\end{array}$ & $\begin{array}{l}\text { Category } \\
\text { total area }\end{array}$ & $\begin{array}{c}\text { Percent- } \\
\text { age of } \\
\text { national } \\
\text { total }\end{array}$ \\
\hline Area of rowcrops harvested (acres) ...... & $6,363,722$ & 2.5 & $5,790,798$ & 2.3 & $5,333,459$ & 2.1 & $5,074,617$ & 2.0 \\
\hline Area fertilized (acres) $\ldots \ldots \ldots \ldots \ldots$ & $4,991,994$ & 2.4 & $4,918,085$ & 2.3 & $4,954,101$ & 2.3 & $4,526,176$ & 2.2 \\
\hline Fertilizer expenses $(x \$ 1000) \ldots \ldots \ldots$ & 59,263 & 0.9 & 184,267 & 2.8 & 182,419 & 2.7 & 142,418 & 2.1 \\
\hline Chemical expenses $(x \$ 1000) \ldots \ldots \ldots$ & 44,889 & 1.0 & 237,690 & 5.1 & 96,238 & 2.1 & 76,617 & 1.6 \\
\hline Area irrigated (acres) $\ldots \ldots \ldots \ldots \ldots$ & 86,839 & 0.2 & $2,777,078$ & 6.0 & $1,811,317$ & 3.9 & 144,507 & 0.3 \\
\hline Number of cattle $\ldots \ldots \ldots \ldots \ldots \ldots$ & 588,545 & 0.6 & $2,118,069$ & 2.2 & $2,895,500$ & 3.0 & $1,379,275$ & 1.5 \\
\hline Number of hogs . . . . . . . . . . . & 112,991 & 0.2 & 201,311 & 0.4 & $2,598,221$ & 5.0 & $1,099,219$ & 2.1 \\
\hline Number of chickens.............. & 81,352 & 0.0 & $5,697,604$ & 0.5 & $101,096,441$ & 8.2 & $42,937,269$ & 3.5 \\
\hline Number of turkeys $\ldots \ldots \ldots \ldots \ldots \ldots$ & 6,498 & 0.0 & 487,854 & 0.8 & 800,702 & 1.3 & $7,019,609$ & 11.3 \\
\hline
\end{tabular}

\begin{tabular}{|c|c|c|c|c|c|c|c|c|}
\hline \multirow{3}{*}{ Characteristic } & \multicolumn{8}{|c|}{ Row crop categories } \\
\hline & \multicolumn{2}{|c|}{$\begin{array}{c}\text { Soybeans }>50 \text { percent, } \\
\text { cotton }>10 \text { percent }\end{array}$} & \multicolumn{2}{|c|}{$\begin{array}{l}\text { Soybeans }>50 \text { percent, } \\
\text { rice }>10 \text { percent }\end{array}$} & \multicolumn{2}{|c|}{$\begin{array}{c}\text { Corn }>20 \text { percent, } \\
\text { alfalfa }>20 \text { percent, } \\
\text { wheat and other } \\
\text { grains }>20 \text { percent }\end{array}$} & \multicolumn{2}{|c|}{$\begin{array}{c}\text { Corn }>20 \text { percent, } \\
\text { wheat and other } \\
\text { grains }>20 \text { percent, } \\
\text { sorghum }>10 \text { percent }\end{array}$} \\
\hline & $\begin{array}{l}\text { Category } \\
\text { total area }\end{array}$ & $\begin{array}{c}\text { Percentage } \\
\text { of national } \\
\text { total }\end{array}$ & $\begin{array}{l}\text { Category } \\
\text { total area }\end{array}$ & $\begin{array}{l}\text { Percent- } \\
\text { age of } \\
\text { national } \\
\text { total }\end{array}$ & $\begin{array}{l}\text { Category } \\
\text { total area }\end{array}$ & $\begin{array}{l}\text { Percent- } \\
\text { age of } \\
\text { national } \\
\text { total }\end{array}$ & $\begin{array}{l}\text { Category } \\
\text { total area }\end{array}$ & $\begin{array}{l}\text { Percent- } \\
\text { age of } \\
\text { national } \\
\text { total }\end{array}$ \\
\hline Area of rowcrops harvested (acres) ...... & $4,968,515$ & 2.0 & $4,251,771$ & 1.7 & $4,224,080$ & 1.7 & $4,089,729$ & 1.6 \\
\hline Area fertilized (acres) $\ldots \ldots \ldots \ldots \ldots$ & $3,220,755$ & 1.5 & $3,090,732$ & 1.5 & $3,926,497$ & 1.9 & $4,504,049$ & 2.1 \\
\hline Fertilizer expenses $(x \$ 1000) \ldots \ldots \ldots \ldots$ & 94,623 & 1.4 & 88,501 & 1.3 & 133,937 & 2.0 & 97,385 & 1.5 \\
\hline Chemical expenses $(x \$ 1000) \ldots \ldots \ldots$. & 152,110 & 3.2 & 80,123 & 1.7 & 73,472 & 1.6 & 51,190 & 1.1 \\
\hline Area irrigated (acres) $\ldots \ldots \ldots \ldots \ldots$ & 876,930 & 1.9 & $2,109,124$ & 4.6 & 800,266 & 1.7 & $1,452,024$ & 3.1 \\
\hline Number of cattle $\ldots \ldots \ldots \ldots \ldots \ldots$ & 548,162 & 0.6 & 278,546 & 0.3 & $2,813,732$ & 2.9 & $3,002,825$ & 3.1 \\
\hline Number of hogs $\ldots \ldots \ldots \ldots \ldots \ldots$ & 147,044 & 0.3 & 31,190 & 0.1 & 648,114 & 1.3 & 427,314 & 0.8 \\
\hline Number of chickens.............. & $23,319,083$ & 1.9 & $6,052,751$ & 0.5 & $46,391,126$ & 3.8 & $14,573,242$ & 1.2 \\
\hline Number of turkeys . . . . . . . . . . . & 421 & 0.0 & 921 & 0.0 & $3,185,339$ & 5.1 & 935,124 & 1.5 \\
\hline
\end{tabular}


Table 4. National characterization of irrigation and fertilizer use and number of cattle, hogs, poultry, and turkeys within each row crop category—Continued

\begin{tabular}{|c|c|c|c|c|c|c|c|c|}
\hline \multirow{3}{*}{ Characteristic } & \multicolumn{8}{|c|}{ Row crop categories } \\
\hline & \multicolumn{2}{|c|}{ Soybeans $>50$ percent } & \multicolumn{2}{|c|}{$\begin{array}{l}\text { Wheat and other } \\
\text { grains }>20 \text { percent, } \\
\text { soybeans }>20 \text { percent }\end{array}$} & \multicolumn{2}{|c|}{$\begin{array}{l}\text { Soybeans }>50 \text { percent } \\
\text { sorghum }>10 \text { percent }\end{array}$} & \multicolumn{2}{|c|}{$\begin{array}{c}\text { Wheat and other } \\
\text { grains }>50 \text { percent, } \\
\text { dried beans and } \\
\text { peas }>10 \text { percent }\end{array}$} \\
\hline & $\begin{array}{l}\text { Category } \\
\text { total area }\end{array}$ & $\begin{array}{l}\text { Percent- } \\
\text { age of } \\
\text { national } \\
\text { total }\end{array}$ & $\begin{array}{l}\text { Category } \\
\text { total area }\end{array}$ & $\begin{array}{l}\text { Percent- } \\
\text { age of } \\
\text { national } \\
\text { total }\end{array}$ & $\begin{array}{l}\text { Category } \\
\text { total area }\end{array}$ & $\begin{array}{c}\text { Percent- } \\
\text { age of } \\
\text { national } \\
\text { total }\end{array}$ & $\begin{array}{l}\text { Category } \\
\text { total area }\end{array}$ & $\begin{array}{c}\text { Percent- } \\
\text { age of } \\
\text { national } \\
\text { total }\end{array}$ \\
\hline Area of rowcrops harvested (acres) ...... & $3,721,710$ & 1.5 & $3,098,042$ & 1.2 & $3,048,424$ & 1.2 & $2,906,463$ & 1.1 \\
\hline Area fertilized (acres) $\ldots \ldots \ldots \ldots \ldots \ldots$ & $2,680,165$ & 1.3 & $2,948,144$ & 1.4 & $2,469,543$ & 1.2 & $2,615,946$ & 1.2 \\
\hline Fertilizer expenses $(x \$ 1000) \ldots \ldots \ldots$ & 72,977 & 1.1 & 81,989 & 1.2 & 58,069 & 0.9 & 61,581 & 0.9 \\
\hline Chemical expenses $(x \$ 1000) \ldots \ldots \ldots$ & 71,691 & 1.5 & 53,265 & 1.1 & 36,621 & 0.8 & 41,502 & 0.9 \\
\hline Area irrigated (acres) $\ldots \ldots \ldots \ldots \ldots$ & 196,204 & 0.4 & 208,680 & 0.5 & 213,950 & 0.5 & 49,729 & 0.1 \\
\hline Number of cattle. . . . . . . . . . . & $1,129,705$ & 1.2 & $1,005,690$ & 1.1 & 916,691 & 1.0 & 154,403 & 0.2 \\
\hline Number of hogs $\ldots \ldots \ldots \ldots \ldots \ldots$ & 411,238 & 0.8 & 279,658 & 0.5 & 398,460 & 0.8 & 39,749 & 0.1 \\
\hline Number of chickens $\ldots \ldots \ldots \ldots \ldots$ & $76,294,010$ & 6.2 & $65,603,988$ & 5.3 & $10,959,238$ & 0.9 & 506,361 & 0.0 \\
\hline Number of turkeys ................ & 523,158 & 0.8 & $1,817,763$ & 2.9 & 212,662 & 0.5 & 568 & 0.0 \\
\hline \multirow{3}{*}{ Characteristic } & \multicolumn{8}{|c|}{ Row crop categories } \\
\hline & \multicolumn{2}{|c|}{$\begin{array}{l}\text { Wheat and other } \\
\text { grains }>50 \text { percent, } \\
\text { cotton }>10 \text { percent }\end{array}$} & \multicolumn{2}{|c|}{$\begin{array}{c}\text { Corn }>20 \text { percent, } \\
\text { soybeans }>20 \text { percent, } \\
\text { sorghum }>10 \text { percent }\end{array}$} & \multicolumn{2}{|c|}{$\begin{array}{l}\text { Cotton }>50 \text { percent, } \\
\text { sorghum }>10 \text { percent }\end{array}$} & \multicolumn{2}{|c|}{$\begin{array}{c}\text { Wheat and other } \\
\text { grains }>20 \text { percent, } \\
\text { soybeans }>20 \text { percent, } \\
\text { sorghum }>10 \text { percent }\end{array}$} \\
\hline & $\begin{array}{l}\text { Category } \\
\text { total area }\end{array}$ & $\begin{array}{c}\text { Percent- } \\
\text { age of } \\
\text { national } \\
\text { total }\end{array}$ & $\begin{array}{l}\text { Category } \\
\text { total area }\end{array}$ & $\begin{array}{c}\text { Percent- } \\
\text { age of } \\
\text { national } \\
\text { total }\end{array}$ & $\begin{array}{l}\text { Category } \\
\text { total area }\end{array}$ & $\begin{array}{c}\text { Percent- } \\
\text { age of } \\
\text { national } \\
\text { total }\end{array}$ & $\begin{array}{l}\text { Category } \\
\text { total area }\end{array}$ & $\begin{array}{c}\text { Percent- } \\
\text { age of } \\
\text { national } \\
\text { total }\end{array}$ \\
\hline Area of rowcrops harvested (acres) . . . . . & $2,759,999$ & 1.1 & $2,646,790$ & 1.0 & $2,180,358$ & 0.9 & $1,868,923$ & 0.7 \\
\hline Area fertilized (acres) $\ldots \ldots \ldots \ldots \ldots$ & $2,082,932$ & 1.0 & $2,288,236$ & 1.1 & $1,800,719$ & 0.9 & $1,953,357$ & 0.9 \\
\hline Fertilizer expenses (x \$1000). . . . . . . . . & 34,648 & 0.5 & 54,394 & 0.8 & 39,939 & 0.6 & 36,959 & 0.6 \\
\hline Chemical expenses $(x \$ 1000) \ldots \ldots \ldots$ & 23,069 & 0.5 & 33,663 & 0.7 & 41,679 & 0.9 & 19,635 & 0.4 \\
\hline Area irrigated (acres) $\ldots \ldots \ldots \ldots \ldots$ & 270,822 & 0.6 & 336,840 & 0.7 & 921,731 & 2.0 & 92,853 & 0.2 \\
\hline Number of cattle $\ldots \ldots \ldots \ldots \ldots \ldots$ & $1,356,437$ & 1.4 & 728,335 & 0.8 & 772,035 & 0.8 & $1,449,523$ & 1.5 \\
\hline Number of hogs . . . . . . . . . . . . & 24,136 & 0.0 & 631,498 & 1.2 & 19,535 & 0.0 & 443,375 & 0.9 \\
\hline Number of chickens.............. & 339,584 & 0.0 & 786,725 & 0.1 & $1,612,085$ & 0.1 & $29,265,443$ & 2.4 \\
\hline Number of turkeys ............... & 574 & 0.0 & 886,291 & 1.4 & 545 & 0.0 & 830,257 & 1.3 \\
\hline
\end{tabular}


Table 4. National characterization of irrigation and fertilizer use and number of cattle, hogs, poultry, and turkeys within each row crop category-Continued

\begin{tabular}{|c|c|c|c|c|c|c|c|c|}
\hline \multirow{3}{*}{ Characteristic } & \multicolumn{8}{|c|}{ Row crop categories } \\
\hline & \multicolumn{2}{|c|}{$\begin{array}{c}\text { Wheat and other } \\
\text { grains }>50 \text { percent, } \\
\text { potatoes }>10 \text { percent }\end{array}$} & \multicolumn{2}{|c|}{ Alfalfa $>50$ percent } & \multicolumn{2}{|c|}{$\begin{array}{c}\text { Corn }>20 \text { percent, } \\
\text { soybeans }>20 \text { percent, } \\
\text { peanuts }>10 \text { percent }\end{array}$} & \multicolumn{2}{|c|}{$\begin{array}{c}\text { Corn }>20 \text { percent, } \\
\text { alfalfa }>20 \text { percent, } \\
\text { vegetables }>10 \text { percent }\end{array}$} \\
\hline & $\begin{array}{c}\text { Category } \\
\text { total area }\end{array}$ & $\begin{array}{c}\text { Percent- } \\
\text { age of } \\
\text { national } \\
\text { total }\end{array}$ & $\begin{array}{l}\text { Category } \\
\text { total area }\end{array}$ & $\begin{array}{l}\text { Percent- } \\
\text { age of } \\
\text { national } \\
\text { total }\end{array}$ & $\begin{array}{c}\text { Category } \\
\text { total area }\end{array}$ & $\begin{array}{l}\text { Percentage } \\
\text { of national } \\
\text { total }\end{array}$ & $\begin{array}{l}\text { Category } \\
\text { total area }\end{array}$ & $\begin{array}{c}\text { Percent- } \\
\text { age of } \\
\text { national } \\
\text { total }\end{array}$ \\
\hline Area of rowcrops harvested (acres) ...... & $1,786,390$ & 0.7 & $1,739,765$ & 0.7 & $1,562,853$ & 0.6 & $1,511,813$ & 0.6 \\
\hline Area fertilized (acres) $\ldots \ldots \ldots \ldots \ldots$ & $1,566,793$ & 0.7 & $2,038,099$ & 1.0 & $1,474,675$ & 0.7 & $1,628,862$ & 0.8 \\
\hline Fertilizer expenses $(\mathrm{x} \$ 1000) \ldots$ & 68,950 & 1.0 & 53,756 & 0.8 & 79,066 & 1.2 & 70,936 & 1.1 \\
\hline Chemical expenses $(x \$ 1000) \ldots \ldots \ldots$. . . & 28,797 & 0.6 & 26,902 & 0.6 & 64,905 & 1.4 & 52,168 & 1.1 \\
\hline Area irrigated (acres) $\ldots \ldots \ldots \ldots \ldots$ & $1,145,722$ & 2.5 & $3,085,029$ & 6.7 & 220,754 & 0.5 & 208,107 & 0.4 \\
\hline Number of cattle $\ldots \ldots \ldots \ldots \ldots \ldots$ & 384,467 & 0.4 & $4,544,185$ & 4.7 & 298,509 & 0.3 & 919,087 & 1.0 \\
\hline Number of hogs . . . . . . . . . . . . & 20,658 & 0.0 & 268,268 & 0.5 & 649,579 & 1.3 & 301,362 & 0.6 \\
\hline Number of chickens. . . . . . . . . . . . . & 18,706 & 0.0 & $64,375,306$ & 5.2 & $21,282,570$ & 1.7 & $10,473,824$ & 0.8 \\
\hline Number of turkeys. . . . . . . . . . . . . & 325 & 0.0 & $2,994,936$ & 4.8 & 491 & 0.0 & 20,365 & 0.0 \\
\hline
\end{tabular}

\begin{tabular}{|c|c|c|c|c|c|c|c|c|}
\hline \multirow{3}{*}{ Characteristic } & \multicolumn{8}{|c|}{ Row crop categories } \\
\hline & \multicolumn{2}{|c|}{$\begin{array}{c}\text { Wheat and other } \\
\text { grains }>50 \text { percent, } \\
\text { sugar beets }>10 \text { percent }\end{array}$} & \multicolumn{2}{|c|}{$\begin{array}{c}\text { Corn }>50 \text { percent, } \\
\text { sorghum }>10 \text { percent }\end{array}$} & \multicolumn{2}{|c|}{ Sorghum $>50$ percent } & \multicolumn{2}{|c|}{$\begin{array}{c}\text { Sorghum }>50 \text { percent, } \\
\text { cotton }>10 \text { percent }\end{array}$} \\
\hline & $\begin{array}{l}\text { Category } \\
\text { total area }\end{array}$ & $\begin{array}{l}\text { Percent- } \\
\text { age of } \\
\text { national } \\
\text { total }\end{array}$ & $\begin{array}{l}\text { Category } \\
\text { total area }\end{array}$ & $\begin{array}{l}\text { Percent- } \\
\text { age of } \\
\text { national } \\
\text { total }\end{array}$ & $\begin{array}{l}\text { Category } \\
\text { total area }\end{array}$ & $\begin{array}{c}\text { Percentage } \\
\text { of national } \\
\text { total }\end{array}$ & $\begin{array}{l}\text { Category } \\
\text { total area }\end{array}$ & $\begin{array}{c}\text { Percent- } \\
\text { age of } \\
\text { national } \\
\text { total }\end{array}$ \\
\hline Area of rowcrops harvested (acres)...... & $1,374,748$ & 0.5 & $1,343,287$ & 0.5 & $1,264,881$ & 0.5 & $1,246,500$ & 0.5 \\
\hline Area fertilized (acres) . . . . . . . . . & $1,290,299$ & 0.6 & $1,370,487$ & 0.6 & $1,188,589$ & 0.6 & $1,241,636$ & 0.6 \\
\hline Fertilizer expenses (x \$1000). & 38,904 & 0.6 & 32,235 & 0.5 & 20,548 & 0.3 & 34,958 & 0.5 \\
\hline Chemical expenses $(x \$ 1000) \ldots \ldots \ldots$ & 28,005 & 0.6 & 21,890 & 0.5 & 15,086 & 0.3 & 39,793 & 0.8 \\
\hline Area irrigated (acres) $\ldots \ldots \ldots \ldots \ldots$ & 249,722 & 0.5 & 825,340 & 1.8 & 218,352 & 0.5 & 247,829 & 0.5 \\
\hline Number of cattle $\ldots \ldots \ldots \ldots \ldots \ldots$ & 115,206 & 0.1 & 581,199 & 0.6 & 659,195 & 0.7 & 501,692 & 0.5 \\
\hline Number of hogs. . . . . . . . . . . & 28,053 & 0.1 & 446,659 & 0.9 & 315,827 & 0.6 & 17,644 & 0.0 \\
\hline Number of chickens $\ldots \ldots \ldots \ldots \ldots$ & 770,520 & 0.1 & $2,290,007$ & 0.2 & $3,043,417$ & 0.2 & 880,331 & 0.1 \\
\hline Number of turkeys $\ldots \ldots \ldots \ldots \ldots \ldots$ & 138 & 0.0 & 14,000 & 0.0 & 24,391 & 0.0 & 133,042 & 0.2 \\
\hline
\end{tabular}


Table 4. National characterization of irrigation and fertilizer use and number of cattle, hogs, poultry, and turkeys within each row crop category—Continued

\begin{tabular}{|c|c|c|c|c|c|c|c|c|}
\hline \multirow{3}{*}{ Characteristic } & \multicolumn{8}{|c|}{ Row crop categories } \\
\hline & \multicolumn{2}{|c|}{$\begin{array}{c}\text { Corn }>20 \text { percent, } \\
\text { wheat and other } \\
\text { grains }>20 \text { percent, } \\
\text { dried beans and } \\
\text { peas }>10 \text { percent }\end{array}$} & \multicolumn{2}{|c|}{ Rice $>50$ percent } & \multicolumn{2}{|c|}{$\begin{array}{l}\text { Wheat and other } \\
\text { grains }>20 \text { percent, } \\
\text { soybeans }>20 \text { percent, } \\
\text { cotton }>10 \text { percent }\end{array}$} & \multicolumn{2}{|c|}{$\begin{array}{c}\text { Corn }>20 \text { percent, } \\
\text { soybeans }>20 \text { percent, } \\
\text { cotton }>10 \text { percent }\end{array}$} \\
\hline & $\begin{array}{c}\text { Category } \\
\text { total area }\end{array}$ & $\begin{array}{c}\text { Percent- } \\
\text { age of } \\
\text { national } \\
\text { total }\end{array}$ & $\begin{array}{l}\text { Category } \\
\text { total area }\end{array}$ & $\begin{array}{c}\text { Percentage } \\
\text { of national } \\
\text { total }\end{array}$ & $\begin{array}{l}\text { Category } \\
\text { total area }\end{array}$ & $\begin{array}{c}\text { Percent- } \\
\text { age of } \\
\text { national } \\
\text { total }\end{array}$ & $\begin{array}{l}\text { Category } \\
\text { total area }\end{array}$ & $\begin{array}{c}\text { Percent- } \\
\text { age of } \\
\text { national } \\
\text { total }\end{array}$ \\
\hline Area of rowcrops harvested (acres). & $1,217,802$ & 0.5 & $1,173,081$ & 0.5 & $1,022,612$ & 0.4 & $1,022,033$ & 0.4 \\
\hline Area fertilized (acres) . . . . . & $1,098,677$ & 0.5 & $1,392,262$ & 0.7 & 845,490 & 0.4 & $1,053,528$ & 0.5 \\
\hline Fertilizer expenses $(x \$ 1000)$. . & 40,421 & 0.6 & 63,363 & 0.9 & 28,010 & 0.4 & 42,347 & 0.6 \\
\hline Chemical expenses (x \$1000). & 16,493 & 0.4 & 59,203 & 1.3 & 26,989 & 0.6 & 33,265 & 0.7 \\
\hline Area irrigated (acres) . . & 430,126 & 0.9 & $1,213,552$ & 2.6 & 108,001 & 0.2 & 59,230 & 0.1 \\
\hline Number of cattle........ & 377,168 & 0.4 & 481,907 & 0.5 & 196,755 & 0.2 & 329,214 & 0.3 \\
\hline Number of hogs . & 96,030 & 0.2 & 25,976 & 0.1 & 43,310 & 0.1 & 315,156 & 0.6 \\
\hline Number of chickens. . & $2,755,006$ & 0.2 & 342,884 & 0.0 & $3,141,277$ & 0.3 & $11,770,610$ & 1.0 \\
\hline Number of turkeys ... & 385 & 0.0 & 406,891 & 0.7 & 99 & 0.0 & 545 & 0.0 \\
\hline \multirow{3}{*}{ Characteristic } & \multicolumn{8}{|c|}{ Row crop categories } \\
\hline & \multicolumn{2}{|c|}{ Vegetables $>50$ percent } & \multicolumn{2}{|c|}{$\begin{array}{c}\text { Corn }>20 \text { percent, } \\
\text { alfalfa }>20 \text { percent, } \\
\text { soybeans }>10 \text { percent }\end{array}$} & \multicolumn{2}{|c|}{$\begin{array}{c}\text { Corn }>20 \text { percent, } \\
\text { soybeans }>20 \text { percent, } \\
\text { vegetables }>10 \text { percent }\end{array}$} & \multicolumn{2}{|c|}{$\begin{array}{c}\text { Wheat and other } \\
\text { grains }>20 \text { percent, } \\
\text { alfalfa }>20 \text { percent, } \\
\text { potatoes }>10 \text { percent }\end{array}$} \\
\hline & $\begin{array}{l}\text { Category } \\
\text { total area }\end{array}$ & $\begin{array}{c}\text { Percent- } \\
\text { age of } \\
\text { national } \\
\text { total }\end{array}$ & $\begin{array}{l}\text { Category } \\
\text { total area }\end{array}$ & $\begin{array}{l}\text { Percent- } \\
\text { age of } \\
\text { national } \\
\text { total }\end{array}$ & $\begin{array}{c}\text { Category } \\
\text { total area }\end{array}$ & $\begin{array}{c}\text { Percent- } \\
\text { age of } \\
\text { national } \\
\text { total }\end{array}$ & $\begin{array}{c}\text { Category } \\
\text { total area }\end{array}$ & $\begin{array}{c}\text { Percentage } \\
\text { of national } \\
\text { total }\end{array}$ \\
\hline Area of rowcrops harvested (acres). & 821,754 & 0.3 & 807,070 & 0.3 & 803,426 & 0.3 & 792,377 & 0.3 \\
\hline Area fertilized (acres) $\ldots \ldots \ldots$ & $2,239,645$ & 1.1 & 677,596 & 0.3 & 844,324 & 0.4 & 702,009 & 0.3 \\
\hline Fertilizer expenses (x \$1000). . & 208,259 & 3.1 & 21,392 & 0.3 & 42,534 & 0.6 & 40,315 & 0.6 \\
\hline Chemical expenses ( $x \$ 1000)$. & 228,425 & 4.9 & 11,821 & 0.3 & 31,255 & 0.7 & 21,730 & 0.5 \\
\hline Area irrigated (acres) . . . . . . . & $1,391,743$ & 3.0 & 9,907 & 0.0 & 113,339 & 0.2 & 802,805 & 1.7 \\
\hline Number of cattle $\ldots \ldots \ldots \ldots \ldots \ldots$ & $2,079,101$ & 2.2 & 445,327 & 0.5 & 228,427 & 0.2 & 401,675 & 0.4 \\
\hline Number of hogs...... & 101,430 & 0.2 & 242,387 & 0.5 & 583,589 & 1.1 & 12,720 & 0.0 \\
\hline Number of chickens............... & $58,553,580$ & 4.7 & $2,475,300$ & 0.2 & $26,056,173$ & 2.1 & 18,246 & 0.0 \\
\hline Number of turkeys $\ldots \ldots \ldots \ldots \ldots \ldots$ & 28,263 & 0.1 & 3,524 & 0.0 & $1,300,934$ & 2.1 & 442 & 0.0 \\
\hline
\end{tabular}


Table 4. National characterization of irrigation and fertilizer use and number of cattle, hogs, poultry, and turkeys within each row crop category-Continued

\begin{tabular}{|c|c|c|c|c|c|c|c|c|}
\hline \multirow{3}{*}{ Characteristic } & \multicolumn{8}{|c|}{ Row crop categories } \\
\hline & \multicolumn{2}{|c|}{$\begin{array}{c}\text { Cotton }>50 \text { percent, } \\
\text { vegetables }>10 \text { percent }\end{array}$} & \multicolumn{2}{|c|}{$\begin{array}{c}\text { Corn }>20 \text { percent, } \\
\text { soybeans }>20 \text { percent, } \\
\text { tobacco }>10 \text { percent }\end{array}$} & \multicolumn{2}{|c|}{ Peanuts $>\mathbf{5 0}$ percent } & \multicolumn{2}{|c|}{$\begin{array}{l}\text { Wheat and other } \\
\text { grains }>20 \text { percent, } \\
\text { alfalfa }>20 \text { percent, } \\
\text { sorghum }>10 \text { percent }\end{array}$} \\
\hline & $\begin{array}{l}\text { Category } \\
\text { total area }\end{array}$ & $\begin{array}{l}\text { Percent- } \\
\text { age of } \\
\text { national } \\
\text { total }\end{array}$ & $\begin{array}{l}\text { Category } \\
\text { total area }\end{array}$ & $\begin{array}{c}\text { Percent- } \\
\text { age of } \\
\text { national } \\
\text { total }\end{array}$ & $\begin{array}{l}\text { Category } \\
\text { total area }\end{array}$ & $\begin{array}{l}\text { Percent- } \\
\text { age of } \\
\text { national } \\
\text { total }\end{array}$ & $\begin{array}{l}\text { Category } \\
\text { total area }\end{array}$ & $\begin{array}{c}\text { Percent- } \\
\text { age of } \\
\text { national } \\
\text { total }\end{array}$ \\
\hline Area of rowcrops harvested (acres) & 787,536 & 0.3 & 735,441 & 0.3 & 693,763 & 0.3 & 689,098 & 0.3 \\
\hline Area fertilized (acres) $\ldots \ldots \ldots \ldots \ldots$ & 967,112 & 0.5 & 699,520 & 0.3 & 998,313 & 0.5 & 494,321 & 0.2 \\
\hline Fertilizer expenses $(x \$ 1000) \ldots \ldots \ldots \ldots$ & 60,672 & 0.9 & 43,437 & 0.7 & 37,398 & 0.6 & 8,706 & 0.1 \\
\hline Chemical expenses $(x \$ 1000) \ldots \ldots \ldots$ & 86,318 & 1.8 & 24,770 & 0.5 & 30,380 & 0.6 & 5,026 & 0.1 \\
\hline Area irrigated (acres) $\ldots \ldots \ldots \ldots \ldots$ & $1,143,449$ & 2.5 & 24,918 & 0.1 & 173,008 & 0.4 & 165,446 & 0.4 \\
\hline Number of cattle............... & 453,822 & 0.5 & 132,011 & 0.1 & 720,849 & 0.8 & 545,795 & 0.6 \\
\hline Number of hogs $\ldots \ldots \ldots \ldots \ldots \ldots$ & 13,065 & 0.0 & 539,497 & 1.0 & 155,572 & 0.3 & 86,290 & 0.2 \\
\hline Number of chickens $\ldots \ldots \ldots \ldots \ldots$ & $8,370,724$ & 0.7 & $6,506,744$ & 0.5 & $15,352,483$ & 1.2 & 538,540 & 0.0 \\
\hline Number of turkeys $\ldots \ldots \ldots \ldots \ldots \ldots$ & $2,635,802$ & 4.3 & 237,750 & 0.4 & 561 & 0.0 & 233,950 & 0.4 \\
\hline
\end{tabular}

\begin{tabular}{|c|c|c|c|c|c|c|c|c|}
\hline \multirow{3}{*}{ Characteristic } & \multicolumn{8}{|c|}{ Row crop categories } \\
\hline & \multicolumn{2}{|c|}{$\begin{aligned} \text { Corn } & >20 \text { percent, } \\
\text { alfalfa } & >20 \text { percent, } \\
\text { tobacco } & >10 \text { percent }\end{aligned}$} & \multicolumn{2}{|c|}{$\begin{array}{c}\text { Corn }>20 \text { percent, } \\
\text { wheat and other } \\
\text { grains }>20 \text { percent, } \\
\text { cotton }>10 \text { percent }\end{array}$} & \multicolumn{2}{|c|}{$\begin{array}{c}\text { Wheat and other } \\
\text { grains }>20 \text { percent, } \\
\text { alfalfa }>20 \text { percent, } \\
\text { cotton }>10 \text { percent }\end{array}$} & \multicolumn{2}{|c|}{$\begin{array}{c}\text { Corn }>20 \text { percent, } \\
\text { soybeans }>20 \text { percent, } \\
\text { dried beans and } \\
\text { peas }>10 \text { percent }\end{array}$} \\
\hline & $\begin{array}{l}\text { Category } \\
\text { total area }\end{array}$ & $\begin{array}{l}\text { Percent- } \\
\text { age of } \\
\text { national } \\
\text { total }\end{array}$ & $\begin{array}{l}\text { Category } \\
\text { total area }\end{array}$ & $\begin{array}{l}\text { Percent- } \\
\text { age of } \\
\text { national } \\
\text { total }\end{array}$ & $\begin{array}{l}\text { Category } \\
\text { total area }\end{array}$ & $\begin{array}{l}\text { Percent- } \\
\text { age of } \\
\text { national } \\
\text { total }\end{array}$ & $\begin{array}{c}\text { Category } \\
\text { total area }\end{array}$ & $\begin{array}{c}\text { Percent- } \\
\text { age of } \\
\text { national } \\
\text { total }\end{array}$ \\
\hline Area of rowcrops harvested (acres). & 680,791 & 0.3 & 677,613 & 0.3 & 647,618 & 0.3 & 645,947 & 0.3 \\
\hline Area fertilized (acres) $\ldots \ldots \ldots \ldots$ & $1,137,250$ & 0.5 & 696,663 & 0.3 & 843,812 & 0.4 & 635,729 & 0.3 \\
\hline Fertilizer expenses (x \$1000). . & 50,309 & 0.8 & 21,220 & 0.3 & 52,754 & 0.8 & 24,072 & 0.4 \\
\hline Chemical expenses ( $\mathrm{x} \$ 1000)$. & 13,778 & 0.3 & 15,705 & 0.3 & 71,973 & 1.5 & 11,201 & 0.2 \\
\hline Area irrigated (acres) $\ldots \ldots \ldots \ldots \ldots$ & 22,334 & 0.0 & 435,667 & 0.9 & $1,046,224$ & 2.3 & 10,923 & 0.0 \\
\hline Number of cattle $\ldots \ldots \ldots \ldots \ldots \ldots$ & $1,521,321$ & 1.6 & 737,414 & 0.8 & 776,195 & 0.8 & 56,110 & 0.1 \\
\hline Number of hogs $\ldots \ldots \ldots \ldots \ldots \ldots$ & 144,679 & 0.3 & 10,046 & 0.0 & 51,888 & 0.1 & 36,415 & 0.1 \\
\hline Number of chickens.............. & $2,584,534$ & 0.2 & $2,140,579$ & 0.2 & $4,985,578$ & 0.4 & 180,795 & 0.0 \\
\hline Number of turkeys $\ldots \ldots \ldots \ldots \ldots \ldots$ & 2,665 & 0.0 & 180,758 & 0.3 & $1,723,260$ & 2.8 & 178 & 2.5 \\
\hline
\end{tabular}


Table 4. National characterization of irrigation and fertilizer use and number of cattle, hogs, poultry, and turkeys within each row crop category—Continued

\begin{tabular}{|c|c|c|c|c|c|c|c|c|}
\hline \multirow{3}{*}{ Characteristic } & \multicolumn{8}{|c|}{ Row crop categories } \\
\hline & \multicolumn{2}{|c|}{$\begin{array}{c}\text { Wheat and other } \\
\text { grains }>20 \text { percent, } \\
\text { alfalfa }>20 \text { percent, } \\
\text { vegetables }>10 \text { percent }\end{array}$} & \multicolumn{2}{|c|}{$\begin{array}{c}\text { Wheat and other } \\
\text { grains }>20 \text { percent, } \\
\text { soybeans }>20 \text { percent, } \\
\text { peanuts }>10 \text { percent }\end{array}$} & \multicolumn{2}{|c|}{$\begin{array}{c}\text { Alfalfa }>50 \text { percent } \\
\text { vegetables }>10 \text { percent }\end{array}$} & \multicolumn{2}{|c|}{$\begin{array}{c}\text { Wheat and other } \\
\text { grains }>20 \text { percent, } \\
\text { alfalfa }>20 \text { percent, } \\
\text { sugarbeets }>10 \text { percent } \\
\end{array}$} \\
\hline & $\begin{array}{l}\text { Category } \\
\text { total area }\end{array}$ & $\begin{array}{l}\text { Percent- } \\
\text { age of } \\
\text { national } \\
\text { total }\end{array}$ & $\begin{array}{l}\text { Category } \\
\text { total area }\end{array}$ & $\begin{array}{l}\text { Percent- } \\
\text { age of } \\
\text { national } \\
\text { total }\end{array}$ & $\begin{array}{l}\text { Category } \\
\text { total area }\end{array}$ & $\begin{array}{c}\text { Percent- } \\
\text { age of } \\
\text { national } \\
\text { total }\end{array}$ & $\begin{array}{l}\text { Category } \\
\text { total area }\end{array}$ & $\begin{array}{c}\text { Percentage } \\
\text { of national } \\
\text { total }\end{array}$ \\
\hline Area of rowcrops harvested (acres) ...... & 608,551 & 0.2 & 552,779 & 0.2 & 550,013 & 0.2 & 518,973 & 0.2 \\
\hline Area fertilized (acres) $\ldots \ldots \ldots \ldots \ldots$ & 899,840 & 0.4 & 563,532 & 0.3 & 915,691 & 0.4 & 460,412 & 0.2 \\
\hline Fertilizer expenses $(x \$ 1000) \ldots \ldots \ldots$. . . & 59,618 & 0.9 & 26,045 & 0.4 & 43,788 & 0.7 & 25,724 & 0.4 \\
\hline Chemical expenses $(x \$ 1000) \ldots \ldots \ldots$ & 65,272 & 1.4 & 21,452 & 0.5 & 40,591 & 0.9 & 12,271 & 0.3 \\
\hline Area irrigated (acres) $\ldots \ldots \ldots \ldots \ldots$ & 931,868 & 2.0 & 127,656 & 0.3 & 591,788 & 1.3 & 664,397 & 1.4 \\
\hline Number of cattle................. & 834,372 & 0.9 & 148,460 & 0.2 & $1,198,900$ & 1.3 & 440,369 & 0.5 \\
\hline Number of hogs $\ldots \ldots \ldots \ldots \ldots \ldots$ & 155,174 & 0.3 & 143,877 & 0.3 & 20,842 & 0.0 & 10,674 & 0.0 \\
\hline Number of chickens .............. & $55,969,407$ & 4.5 & $2,630,684$ & 0.2 & $19,377,277$ & 1.6 & 28,150 & 0.0 \\
\hline Number of turkeys .............. & $1,562,485$ & 2.5 & 726 & 0.0 & 726 & 0.0 & 250 & 0.0 \\
\hline \multirow{2}{*}{ Characteristic } & \multicolumn{2}{|c|}{$\begin{array}{c}\text { Wheat and other } \\
\text { grains }>50 \text { percent, } \\
\text { field grass }>10 \text { percent } \\
\end{array}$} & \multicolumn{2}{|c|}{$\begin{array}{c}\text { Sugar cane }>50 \text { per- } \\
\text { cent, } \\
\text { vegetables }>10 \text { percent }\end{array}$} & \multicolumn{2}{|c|}{ Field grass $>50$ percent } & \multicolumn{2}{|c|}{$\begin{array}{c}\text { Wheat and other } \\
\text { grains }>50 \text { percent, } \\
\text { vegetables }>10 \text { percent }\end{array}$} \\
\hline & $\begin{array}{l}\text { Category } \\
\text { total area }\end{array}$ & $\begin{array}{c}\text { Percent- } \\
\text { age of } \\
\text { national } \\
\text { total }\end{array}$ & $\begin{array}{l}\text { Category } \\
\text { total area }\end{array}$ & $\begin{array}{c}\text { Percent- } \\
\text { age of } \\
\text { national } \\
\text { total }\end{array}$ & $\begin{array}{l}\text { Category } \\
\text { total area }\end{array}$ & $\begin{array}{l}\text { Percent- } \\
\text { age of } \\
\text { national } \\
\text { total }\end{array}$ & $\begin{array}{l}\text { Category } \\
\text { total area }\end{array}$ & $\begin{array}{l}\text { Percentage } \\
\text { of national } \\
\text { total }\end{array}$ \\
\hline Area of rowcrops harvested (acres) ...... & 504,154 & 0.2 & 506,042 & 0.2 & 442,040 & 0.2 & 442,968 & 0.2 \\
\hline Area fertilized (acres) $\ldots \ldots \ldots \ldots \ldots$ & 516,680 & 0.2 & 648,325 & 0.3 & 881,732 & 0.3 & 461,317 & 0.2 \\
\hline Fertilizer expenses $(x \$ 1000) \ldots \ldots \ldots$ & 16,430 & 0.2 & 44,857 & 0.7 & 30,006 & 0.4 & 25,753 & 0.4 \\
\hline Chemical expenses $(\mathrm{x} \$ 1000) \ldots \ldots \ldots$ & 10,617 & 0.2 & 50,672 & 1.1 & 13,287 & 0.3 & 27,717 & 0.6 \\
\hline Area irrigated (acres) $\ldots \ldots \ldots \ldots \ldots$ & 59,011 & 0.1 & 567,427 & 1.2 & 67,379 & 0.1 & 374,944 & 0.8 \\
\hline Number of cattle $\ldots \ldots \ldots \ldots \ldots \ldots$ & 78,435 & 0.1 & 123,228 & 0.1 & 632,677 & 0.7 & 391,829 & 0.4 \\
\hline Number of hogs . . . . . . . . . . . & 26,789 & 0.1 & 657 & 0.0 & 88,744 & 0.2 & 19,792 & 0.0 \\
\hline Number of chickens.............. & 368,159 & 0.0 & 2,830 & 0.0 & $9,719,006$ & 0.8 & $9,845,331$ & 0.8 \\
\hline Number of turkeys ....... & 219,253 & 0.4 & 74 & 0.0 & $1,252,651$ & 2.0 & 62,230 & 0.1 \\
\hline
\end{tabular}


Table 4. National characterization of irrigation and fertilizer use and number of cattle, hogs, poultry, and turkeys within each row crop category-Continued

\begin{tabular}{|c|c|c|c|c|c|c|c|c|}
\hline \multirow{3}{*}{ Characteristic } & \multicolumn{8}{|c|}{ Row crop categories } \\
\hline & \multicolumn{2}{|c|}{ Sugar cane $>50$ percent } & \multicolumn{2}{|c|}{$\begin{array}{c}\text { Corn }>20 \text { percent, } \\
\text { alfalfa }>20 \text { percent, } \\
\text { dried beans and } \\
\text { peas }>10 \text { percent }\end{array}$} & \multicolumn{2}{|c|}{$\begin{array}{c}\text { Corn }>20 \text { percent, } \\
\text { wheat and other } \\
\text { grains }>20 \text { percent, } \\
\text { peanuts }>10 \text { percent }\end{array}$} & \multicolumn{2}{|c|}{$\begin{array}{c}\text { Corn }>20 \text { percent, } \\
\text { wheat and other } \\
\text { grains }>20 \text { percent, } \\
\text { vegetables }>10 \text { percent }\end{array}$} \\
\hline & $\begin{array}{l}\text { Category } \\
\text { total area }\end{array}$ & $\begin{array}{l}\text { Percent- } \\
\text { age of } \\
\text { national } \\
\text { total }\end{array}$ & $\begin{array}{l}\text { Category } \\
\text { total area }\end{array}$ & $\begin{array}{l}\text { Percent- } \\
\text { age of } \\
\text { national } \\
\text { total }\end{array}$ & $\begin{array}{l}\text { Category } \\
\text { total area }\end{array}$ & $\begin{array}{l}\text { Percent- } \\
\text { age of } \\
\text { national } \\
\text { total }\end{array}$ & $\begin{array}{l}\text { Category } \\
\text { total area }\end{array}$ & $\begin{array}{c}\text { Percentage } \\
\text { of national } \\
\text { total }\end{array}$ \\
\hline Area of rowcrops harvested (acres) ...... & 435,088 & 0.2 & 420,575 & 0.2 & 405,251 & 0.2 & 358,501 & 0.1 \\
\hline Area fertilized (acres) $\ldots \ldots \ldots \ldots \ldots$ & 451,037 & 0.2 & 369,267 & 0.2 & 590,078 & 0.3 & 467,757 & 0.2 \\
\hline Fertilizer expenses $(x \$ 1000) \ldots \ldots \ldots$ & 30,629 & 0.5 & 13,763 & 0.2 & 22,079 & 0.3 & 26,698 & 0.4 \\
\hline Chemical expenses $(x \$ 1000) \ldots \ldots \ldots$. & 23,889 & 0.5 & 7,998 & 0.2 & 18,670 & 0.4 & 32,832 & 0.7 \\
\hline Area irrigated (acres) $\ldots \ldots \ldots \ldots \ldots \ldots$ & 105,066 & 0.2 & 301,594 & 0.7 & 187,779 & 0.4 & 350,452 & 0.8 \\
\hline Number of cattle $\ldots \ldots \ldots \ldots \ldots \ldots$ & 249,228 & 0.3 & 254,826 & 0.3 & 341,119 & 0.4 & 450,179 & 0.5 \\
\hline Number of hogs............... & 8,558 & 0.0 & 38,646 & 0.1 & 64,999 & 0.1 & 18,917 & 0.0 \\
\hline Number of chickens............. & 98,997 & 0.0 & 24,355 & 0.0 & $5,085,969$ & 0.4 & $12,753,541$ & 1.0 \\
\hline Number of turkeys............. & 25 & 0.0 & 225 & 0.0 & 318 & 0.0 & $1,738,019$ & 2.8 \\
\hline
\end{tabular}

\begin{tabular}{|c|c|c|c|c|c|c|c|c|}
\hline \multirow{3}{*}{ Characteristic } & \multicolumn{8}{|c|}{ Row crop categories } \\
\hline & \multicolumn{2}{|c|}{$\begin{array}{l}\text { Sorghum }>50 \text { percent, } \\
\text { rice }>10 \text { percent }\end{array}$} & \multicolumn{2}{|c|}{$\begin{array}{l}\text { Field grass }>50 \text { percent, } \\
\text { vegetables }>10 \text { percent }\end{array}$} & \multicolumn{2}{|c|}{$\begin{array}{l}\text { Wheat and other } \\
\text { grains }>20 \text { percent, } \\
\text { alfalfa }>20 \text { percent, } \\
\text { dried beans and } \\
\text { peas }>10 \text { percent }\end{array}$} & \multicolumn{2}{|c|}{$\begin{array}{c}\text { Corn }>20 \text { percent, } \\
\text { wheat and other } \\
\text { grains }>20 \text { percent, } \\
\text { tobacco }>10 \text { percent }\end{array}$} \\
\hline & $\begin{array}{l}\text { Category } \\
\text { total area }\end{array}$ & $\begin{array}{l}\text { Percent- } \\
\text { age of } \\
\text { national } \\
\text { total }\end{array}$ & $\begin{array}{l}\text { Category } \\
\text { total area }\end{array}$ & $\begin{array}{l}\text { Percent- } \\
\text { age of } \\
\text { national } \\
\text { total }\end{array}$ & $\begin{array}{l}\text { Category } \\
\text { total area }\end{array}$ & $\begin{array}{l}\text { Percent- } \\
\text { age of } \\
\text { national } \\
\text { total }\end{array}$ & $\begin{array}{l}\text { Category } \\
\text { total area }\end{array}$ & $\begin{array}{c}\text { Percent- } \\
\text { age of } \\
\text { national } \\
\text { total }\end{array}$ \\
\hline Area of rowcrops harvested (acres) ...... & 337,424 & 0.1 & 260,099 & 0.1 & 245,042 & 0.1 & 233,070 & 0.1 \\
\hline Area fertilized (acres) $\ldots \ldots \ldots \ldots$ & 383,685 & 0.2 & 530,525 & 0.3 & 164,389 & 0.1 & 268,114 & 0.1 \\
\hline Fertilizer expenses (x $\$ 1000) \ldots \ldots \ldots \ldots$ & 13,415 & 0.2 & 30,598 & 0.5 & 6,761 & 0.1 & 13,806 & 0.2 \\
\hline Chemical expenses $(x \$ 1000) \ldots \ldots \ldots$ & 10,025 & 0.2 & 25,712 & 0.5 & 3,228 & 0.1 & 5,116 & 0.1 \\
\hline Area irrigated $($ acres $) \ldots \ldots \ldots \ldots \ldots$ & 121,212 & 0.3 & 216,663 & 0.5 & 210,190 & 0.5 & 20,106 & 0.0 \\
\hline Number of cattle $\ldots \ldots \ldots \ldots \ldots \ldots$ & 118,680 & 0.1 & 283,204 & 0.3 & 128,831 & 0.1 & 207,076 & 0.2 \\
\hline Number of hogs $\ldots \ldots \ldots \ldots \ldots \ldots$ & 663 & 0.0 & 21,525 & 0.0 & 4,660 & 0.0 & 85,265 & 0.2 \\
\hline Number of chickens. . . . . . . . . . & 3,203 & 0.0 & $6,639,551$ & 0.5 & 33,815 & 0.0 & $5,878,134$ & 0.5 \\
\hline Number of turkeys $\ldots \ldots \ldots \ldots \ldots \ldots$ & 120 & 0.0 & 873 & 0.0 & 581 & 0.0 & 47,243 & 0.1 \\
\hline
\end{tabular}


8. Table 4. National characterization of irrigation and fertilizer use and number of cattle, hogs, poultry, and turkeys within each row crop category—Continued

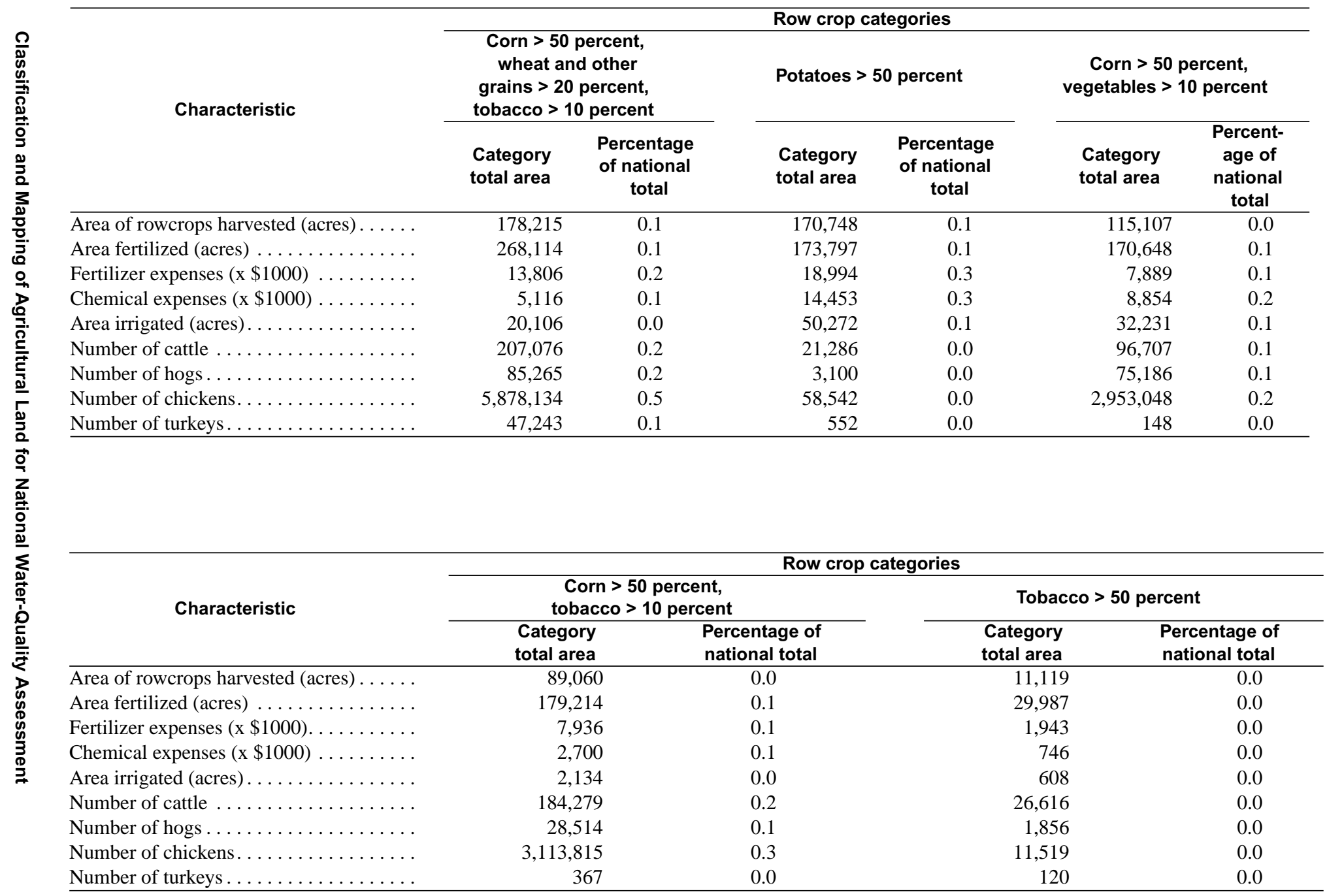


Table 6. National area of orchard, vineyard, and nursery crops within each orchard, vineyard, and nursery category

[All areas are in acres. >, greater than]

\begin{tabular}{|c|c|c|c|c|c|c|c|c|c|}
\hline \multirow[b]{3}{*}{$\begin{array}{l}\text { Individual orchards, } \\
\text { vineyards, } \\
\text { and nurseries }\end{array}$} & \multirow[b]{3}{*}{ National total area } & \multicolumn{8}{|c|}{ Orchards, vineyards, and nurseries } \\
\hline & & \multicolumn{2}{|c|}{ Apples $>50$ percent } & \multicolumn{2}{|c|}{ Cherries $>50$ percent } & \multicolumn{2}{|l|}{ Citrus $>50$ percent } & Grapes $>50$ percent & \multirow[b]{2}{*}{$\begin{array}{c}\text { Percentag } \\
\text { e of } \\
\text { national } \\
\text { total }\end{array}$} \\
\hline & & $\begin{array}{c}\text { Category } \\
\text { total area }\end{array}$ & $\begin{array}{c}\text { Percentag } \\
\text { e of } \\
\text { national } \\
\text { total }\end{array}$ & $\begin{array}{l}\text { Category } \\
\text { total area }\end{array}$ & $\begin{array}{c}\text { Percentag } \\
\text { e of } \\
\text { national } \\
\text { total }\end{array}$ & $\begin{array}{l}\text { Category } \\
\text { total area }\end{array}$ & $\begin{array}{c}\text { Percentag } \\
\text { e of } \\
\text { national } \\
\text { total }\end{array}$ & $\begin{array}{c}\text { Category } \\
\text { total area }\end{array}$ & \\
\hline Apples . & 572,073 & 175,166 & 30.62 & 704 & 0.12 & 131 & 0.02 & 3,236 & 0.57 \\
\hline Grapes & $1,643,828$ & 2,746 & 0.17 & 1,858 & 0.11 & 6,528 & 0.40 & 258,604 & 15.73 \\
\hline Avocados ... & 87,353 & 0 & 0.00 & 0 & 0.00 & 16,075 & 18.40 & 58 & 0.07 \\
\hline Cherries....... & 128,905 & 3,315 & 2.57 & 5,081 & 3.94 & 0 & 0.00 & 570 & 0.44 \\
\hline Nectarines . & 32,077 & 516 & 1.61 & 0 & 0.00 & 0 & 0.00 & 0 & 0.00 \\
\hline Olives.... & 32,318 & 0 & 0.00 & 0 & 0.00 & 0 & 0.00 & 0 & 0.00 \\
\hline Peaches. . & 215,137 & 3,527 & 1.64 & 1,042 & 0.48 & 538 & 0.25 & 707 & 0.33 \\
\hline Pears & 427,146 & 5,281 & 1.24 & 70 & 0.02 & 16 & 0.00 & 3,645 & 0.85 \\
\hline Plums. & 148,774 & 1,504 & 1.01 & 1,032 & 0.69 & 1 & 0.00 & 267 & 0.18 \\
\hline Citrus.. & $1,076,289$ & 0 & 0.00 & 0 & 0.00 & 746,036 & 69.32 & 0 & 0.00 \\
\hline Pecans & 50,877 & 206 & 0.40 & 0 & 0.00 & 27 & 0.05 & 597 & 1.17 \\
\hline Almonds & 427,146 & 0 & 0.00 & 0 & 0.00 & 64 & 0.01 & 95 & 0.02 \\
\hline Filberts. . & 28,588 & 27 & 0.09 & 1,735 & 6.07 & 0 & 0.00 & 0 & 0.00 \\
\hline Walnuts & 213,129 & 42 & 0.02 & 53 & 0.02 & 674 & 0.32 & 1,889 & 0.89 \\
\hline Figs .... & 15,440 & 1 & 0.01 & 0 & 0.00 & 0 & 0.00 & 0 & 0.00 \\
\hline Kiwi........ & 8,040 & 0 & 0.00 & 0 & 0.00 & 31 & 0.39 & 20 & 0.25 \\
\hline Pistachios. $\ldots \ldots \ldots \ldots \ldots \ldots$ & 51,159 & 719 & 1.41 & 0 & 0.00 & 12 & 0.02 & 21 & 0.04 \\
\hline Apricots $\ldots \ldots \ldots \ldots \ldots \ldots$ & 23,029 & 417 & 1.81 & 126 & 0.55 & 267 & 1.16 & 85 & 0.37 \\
\hline Greenhouses and nurseries & 402,367 & 3,180 & 0.79 & 544 & 0.14 & 22,465 & 5.58 & 4,976 & 1.24 \\
\hline $\begin{array}{l}\text { Orchards, vineyards, and nursery } \\
\text { total acres. }\end{array}$ & $4,462,591$ & 195,275 & 4.38 & 11,329 & 0.25 & 790,678 & 17.72 & 145,479 & 3.26 \\
\hline
\end{tabular}


Table 6. National area of orchard, vineyard, and nursery crops within each orchard, vineyard, and nursery category-Continued

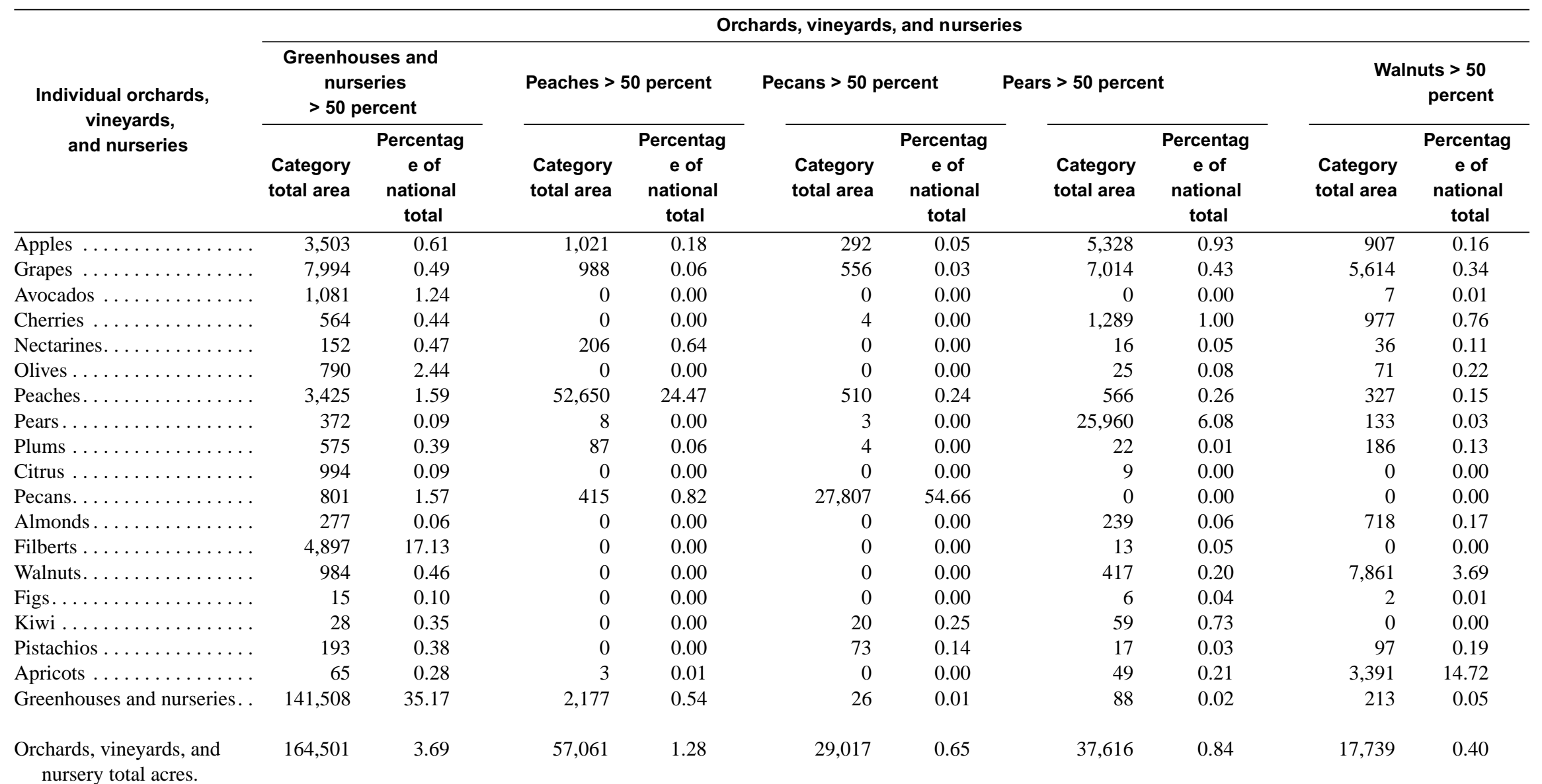


Table 6. National area of orchard, vineyard, and nursery crops within each orchard, vineyard, and nursery category—Continued

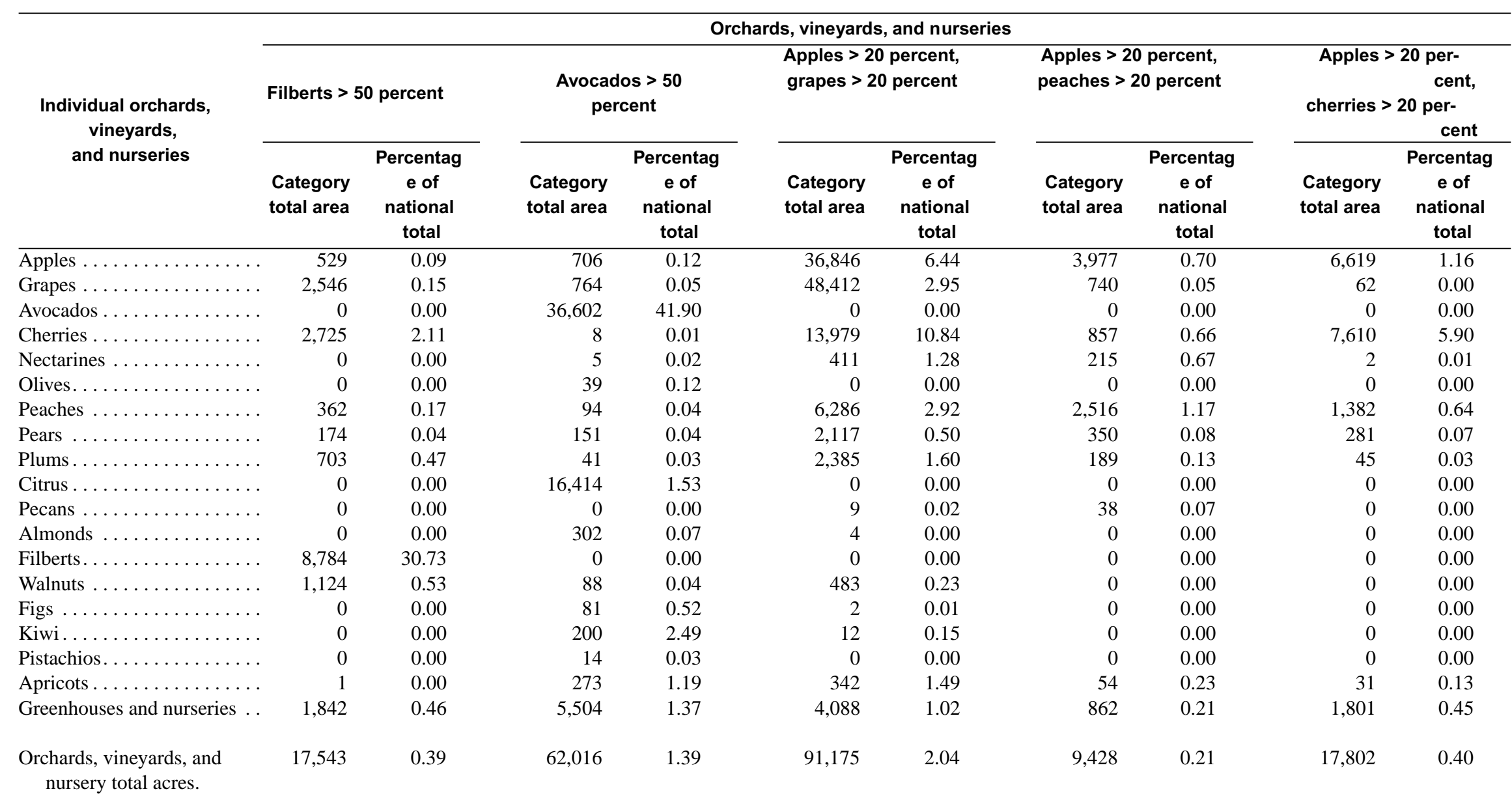


Table 6. National area of orchard, vineyard, and nursery crops within each orchard, vineyard, and nursery category—Continued
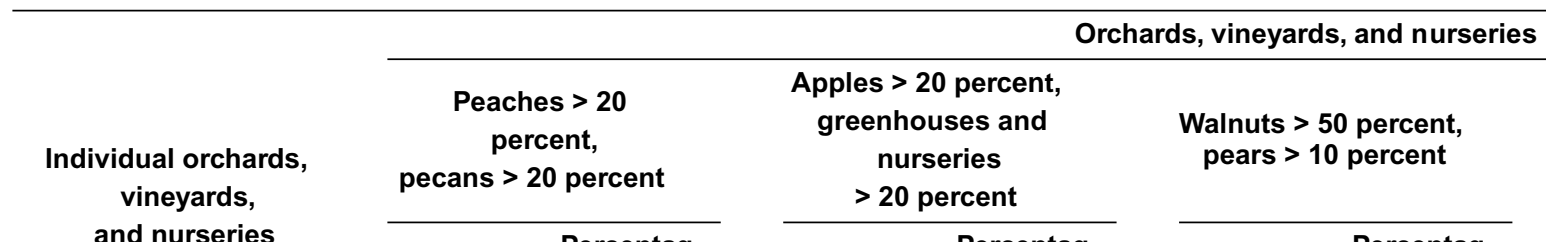

\begin{tabular}{ccc}
\hline Peaches $>20$ & Apples $>20$ percent, & \\
percent, & greenhouses and & Walnuts $>50$ percent, \\
nurseries & pears $>10$ percent
\end{tabular}

Apples $>20$ percent,
greenhouses and
nurseries

$\begin{array}{cc}\text { Percentag } \\ \text { Category } & \text { e of }\end{array}$

\begin{tabular}{cc}
\multicolumn{2}{c}{ nurseries } \\
$>20$ percent \\
\hline Category $\quad \begin{array}{c}\text { Percentag } \\
\text { e of }\end{array}$
\end{tabular}

$\begin{array}{cc}\text { Percentag } \\ \text { Category } & \text { e of }\end{array}$

total area national

total area

e of
national

total

\begin{tabular}{cc}
\multicolumn{2}{c}{$>10$ percent } \\
\hline Category & $\begin{array}{c}\text { Pentag } \\
\text { of }\end{array}$
\end{tabular}

Apples ............. $144 \quad 0.03$

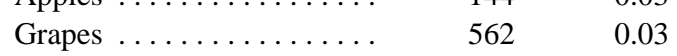

Avocados .............

$\begin{array}{ll}0 & 0.00\end{array}$

Cherries ..............

Nectarines............

Olives ................

$0 \quad 0.00$

$0 \quad 0.00$

Peaches..............

Pears . . . . . . . . . . . . . .

$\begin{array}{ll}0 & 0.00\end{array}$

$\begin{array}{ll}1,001 & 0.47\end{array}$

Plums ...............

Citrus ...............

Pecans.................

Almonds................

Filberts ...............

Walnuts...............

Figs.................

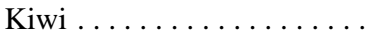

Pistachios .............

Apricots ...............

Greenhouses and nurseries. .

Orchards, vineyards, and nursery total acres.

$\begin{array}{rl}2,523 & 0.44 \\ 952 & 0.06 \\ 0 & 0.00 \\ 320 & 0.25 \\ 53 & 0.17 \\ 0 & 0.00 \\ 1,182 & 0.55 \\ 153 & 0.04 \\ 22 & 0.01 \\ 0 & 0.00 \\ 0 & 0.00 \\ 0 & 0.00 \\ 0 & 0.00 \\ 4 & 0.00 \\ 0 & 0.00 \\ 0 & 0.00 \\ 0 & 0.00 \\ 16 & 0.07 \\ 2,670 & 0.66 \\ 7,419 & 0.17\end{array}$

$\begin{array}{rl}13 & 0.00 \\ 6,808 & 0.41 \\ 0 & 0.00 \\ 0 & 0.00 \\ 0 & 0.00 \\ 0 & 0.00 \\ 42 & 0.02 \\ 5,610 & 1.31 \\ 52 & 0.03 \\ 0 & 0.00 \\ 0 & 0.00 \\ 117 & 0.03 \\ 0 & 0.00 \\ 9,385 & 4.40 \\ 0 & 0.00 \\ 34 & 0.42 \\ 0 & 0.00 \\ 0 & 0.00 \\ 0 & 0.00\end{array}$

0.00

total area

national
total

\section{Apples $>50$ percent,} grapes $>10$ percent

20.00

0.00

1.89

0.00

0.00

0.00

0.00

0.00

0.00

0.00

0.02

0.06

$70,200 \quad 12.27$

$\begin{array}{rr}4,456 & 0.27\end{array}$

222
3,138

0.27
0.25

\begin{tabular}{cc}
\hline & Percentag \\
Category & e of \\
total area & national
\end{tabular}

$\begin{array}{rr}236 & 0.74 \\ 0 & 0.00\end{array}$

2.43

$\begin{array}{rr}0 & 0.00 \\ 3,216 & 1.49\end{array}$

$\begin{array}{ll}3,216 & 1.49 \\ 1,808 & 0.42\end{array}$

$1,131 \quad 0.76$

0.76
0.00

0.00

0.00

0.00
0.00

0.02

0.00
0.12

0.00

10

$18,657 \quad 0.42$

211
31,677

0.92
7.87

114,151

2.56

\begin{tabular}{cc} 
& \multicolumn{1}{c}{ total } \\
\hline 65,356 & 11.42 \\
28,592 & 1.74
\end{tabular}

$5,587 \quad 4.33$

$\begin{array}{rr}466 & 1.45 \\ 0 & 0.00\end{array}$

$\begin{array}{ll}1,741 & 0.81\end{array}$

$\begin{array}{ll}1,741 & 0.81 \\ 10,981 & 2.57\end{array}$

$1,190 \quad 0.80$

$\begin{array}{ll}0 & 0.00\end{array}$

$\begin{array}{ll}11 & 0.02\end{array}$

$\begin{array}{ll}0 & 0.00 \\ 1 & 0.00\end{array}$

$\begin{array}{ll}0 & 0.00 \\ 0 & 0.00\end{array}$

$\begin{array}{ll}0 & 0.00\end{array}$

$\begin{array}{ll}0 & 0.00\end{array}$

$\begin{array}{ll}0 & 0.00 \\ 0 & 0.00\end{array}$

$\begin{array}{ll}0 & 0.00\end{array}$

$\begin{array}{ll}358 & 0.00\end{array}$

$969 \quad 1.55$

$00,957 \quad 2.26$ 
Table 6. National area of orchard, vineyard, and nursery crops within each orchard, vineyard, and nursery category-Continued

\begin{tabular}{|c|c|c|c|c|c|c|c|c|c|c|}
\hline \multirow{4}{*}{$\begin{array}{l}\text { Individual orchards, } \\
\text { vineyards, } \\
\text { and nurseries }\end{array}$} & \multicolumn{10}{|c|}{ Orchards, vineyards, and nurseries } \\
\hline & \multicolumn{2}{|c|}{$\begin{array}{l}\text { Apples }>50 \text { percent, } \\
\text { peaches }>10 \text { percent }\end{array}$} & \multicolumn{2}{|c|}{$\begin{array}{l}\text { Apples }>50 \text { percent, } \\
\text { cherries }>10 \text { percent }\end{array}$} & \multicolumn{2}{|c|}{$\begin{array}{c}\text { Cherries }>50 \text { per- } \\
\text { cent, } \\
\text { apples }>10 \text { percent }\end{array}$} & \multicolumn{2}{|c|}{$\begin{array}{l}\text { Citrus }>20 \text { percent, } \\
\text { grapes }>10 \text { percent }\end{array}$} & \multicolumn{2}{|c|}{$\begin{array}{c}\text { Citrus }>50 \text { percent, } \\
\text { greenhouses and } \\
\text { nurseries } \\
>10 \text { percent } \\
\end{array}$} \\
\hline & & Percentag & & Percentag & & Percentag & & Percentag & & Percentag \\
\hline & $\begin{array}{l}\text { Category } \\
\text { total area }\end{array}$ & $\begin{array}{c}\text { e of } \\
\text { national } \\
\text { total }\end{array}$ & $\begin{array}{l}\text { Category } \\
\text { total area }\end{array}$ & $\begin{array}{c}\text { e of } \\
\text { national } \\
\text { total }\end{array}$ & $\begin{array}{l}\text { Category } \\
\text { total area }\end{array}$ & $\begin{array}{c}\text { e of } \\
\text { national } \\
\text { total }\end{array}$ & $\begin{array}{l}\text { Category } \\
\text { total area }\end{array}$ & $\begin{array}{c}\text { e of } \\
\text { national } \\
\text { total }\end{array}$ & $\begin{array}{l}\text { Category } \\
\text { total area }\end{array}$ & $\begin{array}{c}\text { e of } \\
\text { national } \\
\text { total }\end{array}$ \\
\hline Apples ................ & 65,203 & 11.40 & 62,172 & 10.87 & 14,476 & 2.53 & 346 & 0.06 & 18 & 0.00 \\
\hline Grapes $\ldots \ldots \ldots \ldots \ldots$. & 1,512 & 0.09 & 3,678 & 0.22 & 402 & 0.02 & 14,510 & 0.88 & 138 & 0.01 \\
\hline Avocados ............. & 0 & 0.00 & 0 & 0.00 & 0 & 0.00 & 485 & 0.56 & 2,163 & 2.48 \\
\hline Cherries ............ & 2,636 & 2.04 & 10,971 & 8.51 & 53,989 & 41.88 & 44 & 0.03 & 0 & 0.00 \\
\hline Nectarines ............ & 703 & 2.19 & 49 & 0.15 & 9 & 0.03 & 1 & 0.00 & 0 & 0.00 \\
\hline Olives....... & 0 & 0.00 & 0 & 0.00 & 0 & 0.00 & 0 & 0.00 & 0 & 0.00 \\
\hline Peaches ..... & 17,922 & 8.33 & 1,969 & 0.92 & 2,075 & 0.96 & 166 & 0.08 & 64 & 0.03 \\
\hline Pears ....... & 1,456 & 0.34 & 9,319 & 2.18 & 644 & 0.15 & 24 & 0.01 & 0 & 0.00 \\
\hline Plums........... & 204 & 0.14 & 723 & 0.49 & 1,951 & 1.31 & 17 & 0.01 & 0 & 0.00 \\
\hline Citrus . . . . . . . . . . & 0 & 0.00 & 0 & 0.00 & 0 & 0.00 & 17,940 & 1.67 & 73,876 & 6.86 \\
\hline Pecans $\ldots \ldots \ldots \ldots \ldots$ & 24 & 0.05 & 69 & 0.14 & 0 & 0.00 & 3 & 0.01 & 14 & 0.03 \\
\hline Almonds .............. & 0 & 0.00 & 0 & 0.00 & 0 & 0.00 & 40 & 0.01 & 0 & 0.00 \\
\hline Filberts............ & 0 & 0.00 & 0 & 0.00 & 0 & 0.00 & 0 & 0.00 & 0 & 0.00 \\
\hline Walnuts ............. & 0 & 0.00 & 0 & 0.00 & 0 & 0.00 & 64 & 0.03 & 0 & 0.00 \\
\hline Figs $\ldots \ldots \ldots \ldots \ldots \ldots$ & 0 & 0.00 & 0 & 0.00 & 0 & 0.00 & 1 & 0.01 & 0 & 0.00 \\
\hline Kiwi................. & 0 & 0.00 & 0 & 0.00 & 0 & 0.00 & 40 & 0.50 & 0 & 0.00 \\
\hline Pistachios............ & 0 & 0.00 & 134 & 0.26 & 0 & 0.00 & 372 & 0.73 & 0 & 0.00 \\
\hline Apricots ............. & 33 & 0.14 & 168 & 0.73 & 211 & 0.92 & 240 & 1.04 & 0 & 0.00 \\
\hline Greenhouses and nurseries .. & 2,164 & 0.54 & 764 & 0.19 & 312 & 0.08 & 2,380 & 0.59 & 17,728 & 4.41 \\
\hline $\begin{array}{l}\text { Orchards, vineyards, and } \\
\text { nursery total acres. }\end{array}$ & 91,101 & 2.04 & 88,177 & 1.98 & 73,868 & 1.66 & 29,443 & 0.66 & 93,932 & 2.10 \\
\hline
\end{tabular}


Table 6. National area of orchard, vineyard, and nursery crops within each orchard, vineyard, and nursery category—Continued

\begin{tabular}{|c|c|c|c|c|c|c|c|c|c|c|}
\hline \multirow{3}{*}{$\begin{array}{l}\text { Individual orchards, } \\
\text { vineyards, } \\
\text { and nurseries }\end{array}$} & \multicolumn{10}{|c|}{ Orchards, vineyards, and nurseries } \\
\hline & \multicolumn{2}{|c|}{$\begin{array}{c}\text { Grapes }>50 \text { percent, } \\
\text { apples }>10 \text { percent }\end{array}$} & \multicolumn{2}{|c|}{$\begin{array}{c}\text { Almonds }>50 \\
\text { percent, } \\
\text { greenhouses and } \\
\text { nurseries } \\
>10 \text { percent }\end{array}$} & \multicolumn{2}{|c|}{$\begin{array}{c}\text { Almonds }>50 \\
\text { percent, } \\
\text { grapes }>10 \text { percent }\end{array}$} & \multicolumn{2}{|c|}{$\begin{array}{c}\text { Almonds }>50 \\
\text { percent, } \\
\text { grapes }>10 \text { percent }\end{array}$} & \multicolumn{2}{|c|}{$\begin{array}{l}\text { Macadamias } \\
>50 \text { percent }\end{array}$} \\
\hline & $\begin{array}{l}\text { Category } \\
\text { total area }\end{array}$ & $\begin{array}{l}\text { Percentag } \\
\text { e of } \\
\text { national } \\
\text { total }\end{array}$ & $\begin{array}{l}\text { Category } \\
\text { total area }\end{array}$ & $\begin{array}{c}\text { Percentag } \\
\text { e of } \\
\text { national } \\
\text { total }\end{array}$ & $\begin{array}{l}\text { Category } \\
\text { total area }\end{array}$ & $\begin{array}{l}\text { Percentag } \\
\text { e of } \\
\text { national } \\
\text { total }\end{array}$ & $\begin{array}{l}\text { Category } \\
\text { total area }\end{array}$ & $\begin{array}{c}\text { Percentag } \\
\text { e of } \\
\text { national } \\
\text { total }\end{array}$ & $\begin{array}{l}\text { Category } \\
\text { total area }\end{array}$ & $\begin{array}{c}\text { Percentag } \\
\text { e of } \\
\text { national } \\
\text { total }\end{array}$ \\
\hline$\overline{\text { Apples }}$ & 9,229 & 1.61 & 0 & 0.00 & 0 & 0.00 & 1,105 & 0.19 & 0 & 0.00 \\
\hline Grapes & 86,648 & 5.27 & 164 & 0.01 & 20,066 & 1.22 & 33,750 & 2.05 & 0 & 0.00 \\
\hline Avocados ... & 1 & 0.00 & 0 & 0.00 & 0 & 0.00 & 0 & 0.00 & 519 & 0.59 \\
\hline Cherries & 99 & 0.08 & 0 & 0.00 & 138 & 0.11 & 1,036 & 0.80 & 0 & 0.00 \\
\hline Nectarines. . & 2 & 0.01 & 0 & 0.00 & 231 & 0.72 & 263 & 0.82 & 0 & 0.00 \\
\hline Olives .... & 0 & 0.00 & 0 & 0.00 & 209 & 0.65 & 5,166 & 15.98 & 0 & 0.00 \\
\hline Peaches.... & 604 & 0.28 & 0 & 0.00 & 5,799 & 2.70 & 14,346 & 6.67 & 0 & 0.00 \\
\hline Pears...... & 241 & 0.06 & 7 & 0.00 & 36 & 0.01 & 44 & 0.01 & 0 & 0.00 \\
\hline Plums .... & 1,520 & 1.02 & 3,707 & 2.49 & 2,618 & 1.76 & 19,650 & 13.21 & 0 & 0.00 \\
\hline Citrus ... & 8 & 0.00 & 0 & 0.00 & 240 & 0.02 & 1,747 & 0.16 & 262 & 0.02 \\
\hline Pecans.... & 0 & 0.00 & 0 & 0.00 & 0 & 0.00 & 0 & 0.00 & 0 & 0.00 \\
\hline Almonds. & 2 & 0.00 & 15,965 & 3.74 & 67,269 & 15.75 & 121,332 & 28.41 & 0 & 0.00 \\
\hline Filberts ... & 0 & 0.00 & 0 & 0.00 & 0 & 0.00 & 0 & 0.00 & 0 & 0.00 \\
\hline Walnuts......... & 539 & 0.25 & 4,800 & 2.25 & 8,942 & 4.20 & 49,589 & 23.27 & 0 & 0.00 \\
\hline Figs. $\ldots \ldots \ldots \ldots \ldots$ & 1 & 0.01 & 0 & 0.00 & 4,324 & 28.01 & 10 & 0.06 & 0 & 0.00 \\
\hline Kiwi $\ldots \ldots \ldots \ldots$ & 51 & 0.63 & 12 & 0.15 & 0 & 0.00 & 2,346 & 29.18 & 0 & 0.00 \\
\hline Pistachios . . . . . . . . & 0 & 0.00 & 49 & 0.10 & 4,639 & 9.07 & 1,285 & 2.51 & 0 & 0.00 \\
\hline Apricots . & 0 & 0.00 & 146 & 0.63 & 1,450 & 6.30 & 5,706 & 24.78 & 0 & 0.00 \\
\hline Greenhouses and nurseries. . & 888 & 0.22 & 6,926 & 1.72 & 0 & 0.00 & 1,624 & 0.40 & 1,200 & 0.30 \\
\hline Orchards, vineyards, and & 56,536 & 1.27 & 31,706 & 0.71 & 105,928 & 2.37 & 242,298 & 5.43 & 29,220 & 0.65 \\
\hline
\end{tabular}


Table 6. National area of orchard, vineyard, and nursery crops within each orchard, vineyard, and nursery category-Continued

\begin{tabular}{|c|c|c|c|c|c|c|c|c|c|c|}
\hline \multirow{3}{*}{$\begin{array}{l}\text { Individual orchards, } \\
\text { vineyards, } \\
\text { and nurseries }\end{array}$} & \multicolumn{10}{|c|}{ Orchards, vineyards, and nurseries } \\
\hline & \multicolumn{2}{|c|}{ Bananas $>50$ percent } & \multicolumn{2}{|c|}{$\begin{array}{c}\text { Greenhouses and } \\
\text { nurseries } \\
>50 \text { percent, } \\
\text { citrus }>10 \text { percent }\end{array}$} & \multicolumn{2}{|c|}{$\begin{array}{c}\text { Greenhouses and } \\
\text { nurseries } \\
>50 \text { percent, } \\
\text { peaches }>10 \text { percent }\end{array}$} & \multicolumn{2}{|c|}{$\begin{array}{c}\text { Greenhouses and } \\
\text { nurseries } \\
>\mathbf{5 0} \text { percent, } \\
\text { pecans }>10 \text { percent }\end{array}$} & \multicolumn{2}{|c|}{$\begin{array}{c}\text { Greenhouses and } \\
\text { nurseries } \\
>50 \text { percent, } \\
\text { apples }>10 \\
\text { percent }\end{array}$} \\
\hline & $\begin{array}{l}\text { Category } \\
\text { total area }\end{array}$ & $\begin{array}{l}\text { Percentag } \\
\text { e of } \\
\text { national } \\
\text { total }\end{array}$ & $\begin{array}{l}\text { Category } \\
\text { total area }\end{array}$ & $\begin{array}{l}\text { Percentag } \\
\text { e of } \\
\text { national } \\
\text { total }\end{array}$ & $\begin{array}{l}\text { Category } \\
\text { total area }\end{array}$ & $\begin{array}{l}\text { Percentag } \\
\text { e of } \\
\text { national } \\
\text { total }\end{array}$ & $\begin{array}{l}\text { Category } \\
\text { total area }\end{array}$ & $\begin{array}{l}\text { Percentag } \\
\text { e of } \\
\text { national } \\
\text { total }\end{array}$ & $\begin{array}{l}\text { Category } \\
\text { total area }\end{array}$ & $\begin{array}{c}\text { Percentag } \\
\text { e of } \\
\text { national } \\
\text { total }\end{array}$ \\
\hline$\overline{\text { Apples } \ldots \ldots \ldots \ldots \ldots \ldots}$ & 0 & 0.00 & 8 & 0.00 & 990 & 0.17 & 70 & 0.01 & 19,987 & 3.49 \\
\hline Grapes $\ldots \ldots \ldots \ldots \ldots$. & 0 & 0.00 & 16 & 0.00 & 538 & 0.03 & 286 & 0.02 & 3,188 & 0.19 \\
\hline Avocados ............. & 10 & 0.01 & 0 & 0.00 & 0 & 0.00 & 0 & 0.00 & 0 & 0.00 \\
\hline Cherries..$\ldots \ldots \ldots \ldots$. & 0 & 0.00 & 0 & 0.00 & 7 & 0.01 & 0 & 0.00 & 707 & 0.55 \\
\hline Nectarines ........ & 0 & 0.00 & 0 & 0.00 & 4 & 0.01 & 0 & 0.00 & 10 & 0.03 \\
\hline Olives.............. & 0 & 0.00 & 0 & 0.00 & 0 & 0.00 & 0 & 0.00 & 0 & 0.00 \\
\hline Peaches $\ldots \ldots \ldots \ldots \ldots$ & 0 & 0.00 & 24 & 0.01 & 3,765 & 1.75 & 191 & 0.09 & 2,457 & 1.14 \\
\hline Pears $\ldots \ldots \ldots \ldots \ldots \ldots$ & 0 & 0.00 & 0 & 0.00 & 13 & 0.00 & 0 & 0.00 & 370 & 0.09 \\
\hline Plums . . . . . . . . . . & 0 & 0.00 & 0 & 0.00 & 2 & 0.00 & 0 & 0.00 & 411 & 0.28 \\
\hline Citrus . . . . . . . . & 53 & 0.00 & 21,715 & 2.02 & 0 & 0.00 & 20 & 0.00 & 0 & 0.00 \\
\hline Pecans $\ldots \ldots \ldots \ldots \ldots$ & 0 & 0.00 & 0 & 0.00 & 365 & 0.72 & 983 & 1.93 & 95 & 0.19 \\
\hline Almonds $\ldots \ldots \ldots \ldots \ldots$ & 0 & 0.00 & 0 & 0.00 & 0 & 0.00 & 0 & 0.00 & 0 & 0.00 \\
\hline Filberts........... & 0 & 0.00 & 0 & 0.00 & 0 & 0.00 & 0 & 0.00 & 41 & 0.14 \\
\hline Walnuts $\ldots \ldots \ldots \ldots \ldots$ & 0 & 0.00 & 0 & 0.00 & 0 & 0.00 & 0 & 0.00 & 0 & 0.00 \\
\hline Figs $\ldots \ldots \ldots \ldots \ldots \ldots$ & 0 & 0.00 & 0 & 0.00 & 0 & 0.00 & 0 & 0.00 & 0 & 0.00 \\
\hline Kiwi................ & 0 & 0.0 & 0 & 0.00 & 0 & 0.00 & 0 & 0.00 & 0 & 0.00 \\
\hline Pistachios............ & 0 & 0.00 & 0 & 0.00 & 0 & 0.00 & 0 & 0.00 & 20 & 0.04 \\
\hline Apricots . . . . . . . . . & 0 & 0.00 & 0 & 0.00 & 0 & 0.00 & 0 & 0.00 & 46 & 0.20 \\
\hline Greenhouses and nurseries .. & 535 & 0.13 & 34,781 & 8.64 & 10,322 & 2.57 & 3,331 & 0.83 & 54,167 & 13.46 \\
\hline $\begin{array}{l}\text { Orchards, vineyards, and } \\
\text { nursery total acres. }\end{array}$ & 1,990 & 0.04 & 56,600 & 1.27 & 15,737 & 0.35 & 4,738 & 0.11 & 79,905 & 1.79 \\
\hline
\end{tabular}


Table 6. National area of orchard, vineyard, and nursery crops within each orchard, vineyard, and nursery category—Continued

\begin{tabular}{|c|c|c|c|c|c|c|c|c|c|c|}
\hline \multirow{3}{*}{$\begin{array}{l}\text { Individual orchards, } \\
\text { vineyards, } \\
\text { and nurseries }\end{array}$} & \multicolumn{10}{|c|}{ Orchards, vineyards, and nurseries } \\
\hline & \multicolumn{2}{|c|}{$\begin{array}{c}\text { Peaches }>50 \\
\text { percent, } \\
\text { apples }>10 \text { percent }\end{array}$} & \multicolumn{2}{|c|}{$\begin{array}{c}\text { Peaches }>50 \\
\text { percent, } \\
\text { pecans }>10 \text { percent }\end{array}$} & \multicolumn{2}{|c|}{$\begin{array}{c}\text { Pecans }>50 \text { percent, } \\
\text { apples }>10 \text { percent }\end{array}$} & \multicolumn{2}{|c|}{$\begin{array}{c}\text { Pecans }>50 \text { percent, } \\
\text { greenhouses and } \\
\text { nurseries }>10 \\
\text { percent }\end{array}$} & \multicolumn{2}{|c|}{$\begin{array}{r}\text { Pecans }>50 \\
\text { percent, } \\
\text { peaches }>10 \\
\text { percent }\end{array}$} \\
\hline & $\begin{array}{l}\text { Category } \\
\text { total area }\end{array}$ & $\begin{array}{l}\text { Percentag } \\
\text { e of } \\
\text { national } \\
\text { total }\end{array}$ & $\begin{array}{l}\text { Category } \\
\text { total area }\end{array}$ & $\begin{array}{l}\text { Percentag } \\
\text { e of } \\
\text { national } \\
\text { total }\end{array}$ & $\begin{array}{l}\text { Category } \\
\text { total area }\end{array}$ & $\begin{array}{l}\text { Percentag } \\
\text { e of } \\
\text { national } \\
\text { total }\end{array}$ & $\begin{array}{l}\text { Category } \\
\text { total area }\end{array}$ & $\begin{array}{l}\text { Percentag } \\
\text { e of } \\
\text { national } \\
\text { total }\end{array}$ & $\begin{array}{r}\text { Categor } \\
\text { y } \\
\text { total } \\
\text { area }\end{array}$ & $\begin{array}{l}\text { Percentag } \\
\text { e of } \\
\text { national } \\
\text { total }\end{array}$ \\
\hline$\overline{\text { Apples } \ldots \ldots \ldots \ldots \ldots}$ & 6,173 & 1.08 & 207 & 0.04 & 1,009 & 0.18 & 77 & 0.01 & 243 & 0.04 \\
\hline Grapes $\ldots \ldots \ldots \ldots \ldots$ & 666 & 0.04 & 534 & 0.03 & & 0.00 & 116 & 0.01 & 364 & 0.02 \\
\hline Avocados . . . . . . . . . . . & 0 & 0.00 & 0 & 0.00 & 0 & 0.00 & 0 & 0.00 & 0 & 0.00 \\
\hline Cherries $\ldots \ldots \ldots \ldots \ldots$ & 157 & 0.12 & 0 & 0.00 & 0 & 0.00 & 0 & 0.00 & 0 & 0.00 \\
\hline Nectarines. . . . . . . . . . . . & 35 & 0.11 & 0 & 0.00 & 0 & 0.00 & 0 & 0.00 & 0 & 0.00 \\
\hline Olives . . . . . . . . . . & 0 & 0.00 & 0 & 0.00 & 0 & 0.00 & 0 & 0.00 & 0 & 0.00 \\
\hline Peaches.............. & 24,778 & 11.52 & 7,602 & 3.53 & 370 & 0.17 & 258 & 0.12 & 4,006 & 1.86 \\
\hline Pears............. & 312 & 0.07 & 0 & 0.00 & 0 & 0.00 & 0 & 0.00 & 0 & 0.00 \\
\hline Plums . . . . . . . . . & 96 & 0.06 & 2 & 0.00 & 5 & 0.00 & 0 & 0.00 & 6 & 0.00 \\
\hline Citrus & 0 & 0.00 & 0 & 0.00 & 0 & 0.00 & 0 & 0.00 & 0 & 0.00 \\
\hline Pecans....... & 82 & 0.16 & 2,704 & 5.31 & 2,489 & 4.89 & 2,379 & 4.68 & 10,794 & 21.22 \\
\hline Almonds . . . . . . . . . . & 0 & 0.00 & 0 & 0.00 & 0 & 0.00 & 0 & 0.00 & 0 & 0.00 \\
\hline Filberts . . . . . . . . . . & 0 & 0.00 & 0 & 0.00 & 0 & 0.00 & 0 & 0.00 & 0 & 0.00 \\
\hline Walnuts. . . . . . . . . . & 0 & 0.00 & 0 & 0.00 & 0 & 0.00 & 0 & 0.00 & 0 & 0.00 \\
\hline Figs. . . . . . . . . & 0 & 0.00 & 0 & 0.00 & 0 & 0.00 & 0 & 0.00 & 0 & 0.00 \\
\hline Kiwi ................ & 0 & 0.00 & 0 & 0.00 & 0 & 0.00 & 0 & 0.00 & 0 & 0.00 \\
\hline Pistachios . . . . . . . . . . & 0 & 0.00 & 0 & 0.00 & 0 & 0.00 & 22 & 0.04 & 0 & 0.00 \\
\hline Apricots $\ldots \ldots \ldots \ldots \ldots$ & 97 & 0.42 & 0 & 0.00 & 0 & 0.00 & 0 & 0.00 & 0 & 0.00 \\
\hline Greenhouses and nurseries. . & 2,150 & 0.53 & 113 & 0.03 & 36 & 0.01 & 1,053 & 0.26 & 108 & 0.03 \\
\hline $\begin{array}{l}\text { Orchards, vineyards, and } \\
\text { nursery total acres. }\end{array}$ & 34,213 & 0.77 & 10,895 & 0.24 & 3,940 & 0.09 & 3,847 & 0.09 & 15,339 & 0.34 \\
\hline
\end{tabular}


Table 6. National area of orchard, vineyard, and nursery crops within each orchard, vineyard, and nursery category-Continued

\begin{tabular}{|c|c|c|c|c|c|c|c|c|c|c|}
\hline \multirow{4}{*}{$\begin{array}{l}\text { Individual orchards, } \\
\text { vineyards, } \\
\text { and nurseries }\end{array}$} & \multicolumn{10}{|c|}{ Orchards, vineyards, and nurseries } \\
\hline & \multicolumn{2}{|c|}{$\begin{array}{l}\text { Grapes }>50 \text { percent, } \\
\text { almonds }>10 \text { percent }\end{array}$} & \multicolumn{2}{|c|}{$\begin{array}{l}\text { Grapes }>20 \text { percent, } \\
\text { almonds }>10 \text { percent }\end{array}$} & \multicolumn{2}{|c|}{$\begin{array}{c}\text { Grapes }>20 \text { percent, } \\
\text { avocados }>20 \\
\text { percent }\end{array}$} & \multicolumn{2}{|c|}{$\begin{array}{c}\text { Walnuts }>20 \text { percent, } \\
\text { plums }>20 \text { percent }\end{array}$} & \multicolumn{2}{|c|}{$\begin{array}{r}\text { Walnuts }>20 \\
\text { percent, } \\
\text { almonds }>20 \\
\text { percent }\end{array}$} \\
\hline & & Percentag & & Percentag & & Percentag & & Percentag & Categor & Percentag \\
\hline & $\begin{array}{l}\text { Category } \\
\text { total area }\end{array}$ & $\begin{array}{c}\text { e of } \\
\text { national } \\
\text { total }\end{array}$ & $\begin{array}{l}\text { Category } \\
\text { total area }\end{array}$ & $\begin{array}{c}\text { e of } \\
\text { national } \\
\text { total }\end{array}$ & $\begin{array}{l}\text { Category } \\
\text { total area }\end{array}$ & $\begin{array}{c}\text { e of } \\
\text { national } \\
\text { total }\end{array}$ & $\begin{array}{l}\text { Category } \\
\text { total area }\end{array}$ & $\begin{array}{c}\text { e of } \\
\text { national } \\
\text { total }\end{array}$ & $\begin{array}{l}y \\
\text { total } \\
\text { area }\end{array}$ & $\begin{array}{c}\text { e of } \\
\text { national } \\
\text { total }\end{array}$ \\
\hline$\ldots \ldots \ldots \ldots \ldots$ & 2,194 & 0.38 & 6,829 & 1.19 & 125 & 0.02 & 1,461 & 0.26 & 96 & 0.02 \\
\hline Grapes .............. & 579,234 & 35.24 & 278,054 & 16.92 & 24,026 & 1.46 & 10,406 & 0.63 & 3,960 & 0.24 \\
\hline Avocados ............ & 280 & 0.32 & 1,491 & 1.71 & 8,862 & 10.15 & 13 & 0.01 & 0 & 0.00 \\
\hline Cherries ............. & 79 & 0.06 & 9,858 & 7.65 & 1 & 0.00 & 1,032 & 0.80 & 0 & 0.00 \\
\hline Nectarines...$\ldots \ldots \ldots$. & 14,780 & 46.08 & 3,036 & 9.46 & 1 & 0.00 & 102 & 0.32 & 12 & 0.04 \\
\hline Olives. . . . . . . . . . & 3,518 & 10.89 & 1,483 & 4.59 & 7 & 0.02 & 4,804 & 14.86 & 0 & 0.00 \\
\hline Peaches $\ldots \ldots \ldots \ldots \ldots$. & 15,503 & 7.21 & 8,454 & 3.93 & 6 & 0.00 & 15,534 & 7.22 & 108 & 0.05 \\
\hline Pears $\ldots \ldots \ldots \ldots \ldots \ldots$ & 964 & 0.23 & 979 & 0.23 & 1 & 0.00 & 6,806 & 1.59 & 721 & 0.17 \\
\hline Plums............ & 22,113 & 14.86 & 6,670 & 4.48 & 9 & 0.01 & 50,338 & 33.84 & 2,267 & 1.52 \\
\hline$\ldots \ldots \ldots \ldots \ldots$ & 28,656 & 2.66 & 35,616 & 3.31 & 1,909 & 0.18 & 150 & 0.01 & 166 & 0.02 \\
\hline Pecans $\ldots \ldots \ldots \ldots \ldots$ & 0 & 0.00 & 1 & 0.00 & 0 & 0.00 & 0 & 0.00 & 0 & 0.00 \\
\hline Almonds $\ldots \ldots \ldots \ldots \ldots$ & 66,207 & 15.50 & 123,197 & 28.84 & 0 & 0.00 & 15,440 & 3.61 & 7,628 & 1.79 \\
\hline Filberts............. & 0 & 0.00 & 0 & 0.00 & 0 & 0.00 & 42 & 0.15 & 0 & 0.00 \\
\hline Walnuts $\ldots \ldots \ldots \ldots \ldots$ & 5,801 & 2.72 & 44,068 & 20.68 & 671 & 0.31 & 39,911 & 18.73 & 7,716 & 3.62 \\
\hline Figs $\ldots \ldots \ldots \ldots \ldots \ldots$ & 10,754 & 69.65 & 5 & 0.03 & 1 & 0.01 & 11 & 0.07 & 109 & 0.71 \\
\hline Kiwi............... & 568 & 7.06 & 1,263 & 15.71 & 9 & 0.11 & 1,051 & 13.07 & 151 & 1.88 \\
\hline Pistachios . . . . . . . . . . . & 18,122 & 35.42 & 20,930 & 40.91 & 435 & 0.85 & 460 & 0.90 & 46 & 0.09 \\
\hline Apricots ............. & 995 & 4.32 & 4,435 & 19.26 & 35 & 0.15 & 2,678 & 11.63 & 479 & 2.08 \\
\hline Greenhouses and nurseries .. & 830 & 0.21 & 8,546 & 2.12 & 4,419 & 1.10 & 4,282 & 1.06 & 561 & 0.14 \\
\hline $\begin{array}{l}\text { Orchards, vineyards, and } \\
\text { nursery total acres. }\end{array}$ & 482,434 & 10.81 & 416,380 & 9.33 & 28,782 & 0.64 & 149,631 & 3.35 & 22,042 & 0.49 \\
\hline
\end{tabular}


o Table 6. National area of orchard, vineyard, and nursery crops within each orchard, vineyard, and nursery category-Continued

\begin{tabular}{|c|c|c|c|c|c|c|}
\hline \multirow{3}{*}{$\begin{array}{l}\text { Individual orchards, } \\
\text { vineyards, } \\
\text { and nurseries }\end{array}$} & \multicolumn{6}{|c|}{ Orchards, vineyards, and nurseries } \\
\hline & \multicolumn{2}{|c|}{$\begin{array}{c}\text { Grapes }>20 \text { percent, } \\
\text { citrus }>20 \text { percent }\end{array}$} & \multicolumn{2}{|c|}{$\begin{array}{l}\text { Avocados }>20 \text { percent } \\
\text { citrus }>20 \text { percent }\end{array}$} & \multicolumn{2}{|c|}{$\begin{array}{c}\text { Filberts }>20 \text { percent, } \\
\text { greenhouses and nurseries } \\
>20 \text { percent }\end{array}$} \\
\hline & $\begin{array}{l}\text { Category } \\
\text { total area }\end{array}$ & $\begin{array}{l}\text { Percentage of } \\
\text { national total }\end{array}$ & $\begin{array}{l}\text { Category } \\
\text { total area }\end{array}$ & $\begin{array}{l}\text { Percentage of } \\
\text { national total }\end{array}$ & $\begin{array}{l}\text { Category } \\
\text { total area }\end{array}$ & $\begin{array}{l}\text { Percentage of } \\
\text { national total }\end{array}$ \\
\hline$\ldots \ldots \ldots \ldots \ldots$ & 1,691 & 0.30 & 0 & 0.00 & 1,163 & 0.20 \\
\hline Grapes $\ldots \ldots \ldots \ldots \ldots \ldots \ldots$ & 192,934 & 11.74 & 0 & 0.00 & 2,780 & 0.17 \\
\hline Avocados $\ldots \ldots \ldots \ldots \ldots \ldots \ldots$ & 12,153 & 13.91 & 7,331 & 0.00 & 0 & 0.00 \\
\hline Cherries $\ldots \ldots \ldots \ldots \ldots \ldots \ldots$ & 221 & 0.17 & 0 & 0.00 & 1,906 & 1.48 \\
\hline Nectarines. . . . . . . . . . . . . . . . & 10,514 & 32.78 & 0 & 0.00 & 11 & 0.03 \\
\hline Olives . . . . . . . . . . . . . . . . & 16,206 & 50.15 & 0 & 0.00 & 0 & 0.00 \\
\hline Peaches................... & 7,418 & 3.45 & 0 & 0.00 & 604 & 0.28 \\
\hline Pears $\ldots \ldots \ldots \ldots \ldots \ldots \ldots \ldots$ & 1,404 & 0.33 & 0 & 0.00 & 438 & 0.10 \\
\hline Plums $\ldots \ldots \ldots \ldots \ldots \ldots \ldots$ & 26,098 & 17.54 & 0 & 0.00 & 929 & 0.62 \\
\hline Citrus $\ldots \ldots \ldots \ldots \ldots \ldots \ldots \ldots$ & 124,362 & 11.55 & 6,112 & 0.57 & 0 & 0.00 \\
\hline Pecans. . . . . . . . . . . . . . & 0 & 0.00 & 0 & 0.00 & 0 & 0.00 \\
\hline Almonds . . . . . . . . . . . & 8,249 & 1.93 & 0 & 0.00 & 0 & 0.00 \\
\hline Filberts $\ldots \ldots \ldots \ldots \ldots \ldots \ldots$ & 0 & 0.00 & 0 & 0.00 & 13,049 & 45.65 \\
\hline Walnuts. . . . . . . . . . . . & 26,589 & 12.48 & 0 & 0.00 & 1,401 & 0.66 \\
\hline 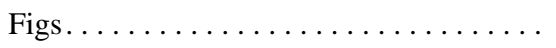 & 117 & 0.76 & 0 & 0.00 & 0 & 0.00 \\
\hline Kiwi $\ldots \ldots \ldots \ldots \ldots \ldots \ldots \ldots$ & 2,135 & 26.55 & 0 & 0.00 & 0 & 0.00 \\
\hline Pistachios $\ldots \ldots \ldots \ldots \ldots \ldots \ldots$ & 3,499 & 6.84 & 0 & 0.00 & 0 & 0.00 \\
\hline Apricots $\ldots \ldots \ldots \ldots \ldots \ldots \ldots$ & 621 & 2.70 & 0 & 0.00 & 0 & 0.00 \\
\hline Greenhouses and nurseries.......... & 3,816 & 0.95 & 4,558 & 1.13 & 10,095 & 2.51 \\
\hline $\begin{array}{l}\text { Orchards, vineyards, and nursery } \\
\text { total acres. }\end{array}$ & 350,636 & 7.86 & 21,951 & 0.49 & 31,001 & 0.69 \\
\hline
\end{tabular}

